\title{
TO THE CHEVRON STATION: AN EMPIRICAL STUDY OF FEDERAL ADMINISTRATIVE LAW
}

\author{
Peter H. SchucK* \\ E. DONALD ELLIOTT**
}

TABLE OF CONTENTS

I. Introduction $\ldots \ldots \ldots \ldots \ldots \ldots \ldots \ldots \ldots \ldots \ldots \ldots \ldots \ldots \ldots, 985$

II. Objectives and Study Design ....................... 989

III. Findings and Analysis .......................... 996

A. The Changing Style of Appellate Opinions .......... 996

1. Table Decisions ............................ 999

2. The Length and Footnoting of Opinions .......... 1003

3. The Fragmentation of Decisions................. 1004

B. The Ages of Administrative Law .................. 1007

1. The Outcomes of Judicial Review ............... 1007

2. Types of Agency Proceedings .................... 1013

3. Review of Particular Agencies.................. 1015

4. Circuit Court Caseloads ...................... 1017

5. The Composition of Reviewing Courts ............ 1018

C. Remands and the Chevron Effect ................ 1020

Copyright (C) Peter H. Schuck and E. Donald Elliott 1991.

- Simeon E. Baldwin Professor of Law, Yale Law School.

* Assistant Administrator and General Counsel, U.S. Environmental Protection Agency; Professor of Law, Yale Law School (on leave of absence).

The views expressed in this Article are the personal views of the authors and do not necessarily reflect those of the Environmental Protection Agency (EPA), the United States Government, the Administrative Conference of the United States (ACUS), or any other organization or group. The authors wish to acknowledge the financial support of the ACUS under contract \#AC8702013 and of the Yale Law School's Center for Studies in Law, Economics and Public Policy, as well as the research assistance of many students at Georgetown University Law Center and Yale Law School. Of these, David Ehas and Nancy Ribaudo of Georgetown, and Bob Easton and Tim Obst of Yale deserve special inention and thanks. Vik Raina, a computer science student at Yale, assisted Professor Elliott with programming. We are also grateful for the comments and suggestions received at the Yale Law School Faculty Workshop, and the discussion at the 1989 meetings of the Administrative Law sections of the Association of American Law Schools and the American Bar Association. Our colleague at Yale, Professor Roberta Romano, deserves special mention for her help in refining our techniques for analyzing some of our data, as well as for her trenchant comments on earber drafts, as does Peter Strauss, who picked up errors and pointed to promising lines of imquiry. We, of course, are solely responsible for any errors that remain. 
1. The Pattern of Remands: Remands During $1984-85$...................................... 1020

2. The Effects of Chevron ..................... 1023

a. The outcomes effect .................... 1029

b. The outcome displacement effect ............ 1031

c. The reasons displacement effect ............. 1032

3. Persistence of Effects ......................... 1036

4. Court-Specific Effects ....................... 1041

5. Agency-Specific Effects ...................... 1043

D. What Happens After Remand? .................. 1043

1. Post-Remand Procedures ....................... 1044

2. Post-Remand Outcomes ...................... 1046

3. The Duration of Post-Remand Proceedings ........ 1049

4. Significant Post-Remand Events ................ 1051

IV. Summary of Principal Findings ................... 1054

A. The Changing Style of Appellate Opinions .......... 1055

B. The Ages of Administrative Law .................. 1057

C. Remands and the Chevron Effect ................. 1058

D. What Happens After Remand? ................... 1059

V. Conclusion ................................... 1060

Appendix A-Agencies and Agency Groupings............. 1062

Appendix B-Coding Sheet ........................... 1064

Appendix C-Use of WESTLAW in Einpirical Research........ 1068

Appendix D-Data on the Length and Footnoting of Opinions .. 1070 Appendix E-Reconciliation With Administrative Office Data ... 1075

\section{INTRODUCTION}

We begin with a puzzling fact. Although the stndy of administrative law began in earnest inore than fifty years ago, we still know hittle about what is perhaps the central question in that field: How does judicial review actually affect agency decisionmaking? This question goes to the fundamental nature and quality of the inodern administrative state, 
yet academic specialists have largely neglected it; ${ }^{1}$ the subject remains a matter for uninformed speculation. ${ }^{2}$

Despite (or perhaps because of) the lack of data, however, strong opinions on this question are common. Our conversations and our reading persuade us that every self-respectimg administrative lawyer has firm, if not always articulate or even consistent, convictions about the effect of judicial review upon agencies. Proof of this assertion abounds. Lawyers and their chents devote vast resources to challenging agency actions im the courts. ${ }^{3}$ With Talmudic intensity, legions of legal scholars analyze the language and logic of judicial opinions in administrative law cases. ${ }^{4}$ Agencies theinselves exhibit great concern about how reviewing courts respond to their handiwork. Manifestly, the "experts" act as if judicial review of agency action were worth fighting, writing, and worrying about. They beheve, in short, that what courts say to agencies matters, and matters deeply.

But although there may be widespread agreennent that judicial review of agency action matters, there is no consensus about preeisely how and under what circumstances it matters. As Jerry Mashaw and David Harfst recently put it, "The normative expectations of administrative lawyers have seldom been subjected to empirical verification of a more

1. The few exceptions in the legal literature involve a consideration of this question in quite particular contexts. See, e.g., Leventhal, Environmental Decisionmaking and the Role of the Courts, 122 U. PA. L. REV. 509, 554-55 (1974) (discussing EPA's response to remand in International Harvester Co. v. Ruckelshaus, 478 F.2d 615 (D.C. Cir. 1973)); Williams, "Hybrid Rulemaking" under the Administrative Procedure Act: A Legal and Empirical Analysis, 42 U. CHI. L. REv. 401, 425-36 (1975) (discussing responses by three agencies to judicial interpretation of APA requiring inore formal procedures in informal rulemaking by EPA). A broader empirical study of the court-agency relationship, Gardner, Federal Courts and Agencies: An Audit of the Partnership Books, 75 CoLUM. L. REV. 800 (1975), focuses upon judicial strategies of supervision rather than upon how agencies respond to remands. For a critique of the regulatory role of public tort law, see P. SCHUCK, SuING GOVERNMENT: CITIZEN REMEDIES FOR OfFICIAL WRONGS 3-12, 125-81 (1983).

Some political scientists also have examined this question. See, eg., R. MELNICK, Regulation and the Courts: The Case of the Clean AIr Act (1983); S. Wasby, The Supreme COURT IN THE FEderal Judicial System (1988).

2. This irony, of course, is common to all fields, not just law. By soine perversity of intellectual inquiry, the inost mteresting and important questions in life are usually the most elusive and opaque.

3. The number of administrative law cases in the federal appellate courts is large and growing. See infra Chart 1.

4. There are several publications devoted exclusively to administrative law doctrine. See, e.g., ADMIN. L. REV. (published by the American Bar Association); ADMIN. L.J. (published by American University). There are also numerous specialized journals concerned with judicial review of agency decisions in particular policy areas, e.g., J. AIR L. \& COMM.; J. ENERGY L. \& POL'Y; and at least one leading law review publishes an annual administrative law issue, see Duke L.J. 
than anecdotal sort."s And different observers evidently rely upon different anecdotes.

Virtually all administrative law writers and teachers at one time or another assiduously seek to expand and fine-tune judicial review of agency action, and they usually advocate a variety of institutional and doctrinal reforms for those purposes. ${ }^{6}$ They suppose, at least by implication, that what courts do matters substantively-that when a court decides that an agency erred or failed adequately to support its action, the court's ruling actually (and not just norinatively) controls the agency's subsequent behavior in that case. This behavioral supposition, after all, is one of the raisons d'etre of most of administrative law. The conventional explanation for judicial review of agency action is the need to confine agencies to their legal authority. To deny that courts actually perforn this task is to raise dark and difficult questions about the compatibility of the administrative state with the rule of law. ${ }^{7}$

On the other hand, academic discussion of these questions (sometimes by the very same writers) often proceeds as if the axiom of judicial control of agency action were empirically false. ${ }^{8}$ Certain mexorable conditions, it is said, limit the capacity of reviewing courts to shape an agency's conduct. Poimting to factors such as the narrow "bite" of legal doctrine, the political context of administrative decisionmaking, judicial deference to agency expertise, the scope of agency discretion, an agency's control of its agenda, the limited resources of litigants, and the protracted nature of agency proceedings, these commentators emphasize that in practice, if not in principle, an agency usually lias the last word as well as the first.9 Writing more than twenty years ago, political scientist Martin Shapiro crystallized this view in the statement that "courts typically let the agency do wliat it plcases." 10

5. Mashaw \& Harfst, Regulation and Legal Culture: The Case of Motor Vehicle Safety, 4 YALE J. REg. 257, 275 (1987). See generally Schuck, Why Don't Law Professors Do More Empirical Research?, 39 J. LEGAI EDUc. 323 (1989).

6. E.g., K. Davis, Discretionary Justice: A Preliminary Inquiry 54-59, 219-22 (1971) (advocating a form of the non-delegation doctrine that would encourage agencies to confine their discretionary power through rulemaking); Strauss, The Place of Agencies in Government: Separation of Powers and the Fourth Branch, 84 CoLUM. L. REv. 573, 578 (1984) (arguing for the abandonment of "rigid separation of powers compartmentalization" in favor of a inore practical analysis in terms of "separation of functions and checks and balances"). (1983).

7. See, e.g., Monaghan, Marbury and the Administrative State, 83 Colum. L. Rev. 1, 6

8. See, eg., K. DAVIS, supra note 6, at 27-28, 215-16 (agency discretion limits effectiveness of judicial review).

9. Practitioners, needless to say, find themselves on all sides of this question; their positions depend not only upon their experiences and orientations but also upon whether they are seeking to persuade their clients to challenge or to defend the agency's position.

10. M. Shapiro, The Supreme CoURt AND Administrative Agencies 265 (1968). 
Which of these views is correct? We suspect that there is considerable truth in both views-that judicial review "matters" in all cases (if only because review occasions delay and additional cost before the agency's action can be implemented), but that it has different effects which depend upon a variety of factors. That much, of course, can be confidently asserted about virtually any legal phenomenon as complex as the interaction between courts and agencies. The more interesting and challenging question is whether research can identify those factors and effects, discern significant patterus in the relationship between them, and derive systematic conclusions that can illuminate the ways in which reviewing courts actually shape agency behavior.

Believing that the possibility of such research must at least be entertained, we undertook a large-scale empirical study of how federal agency actions fare when they are reviewed directly by appellate courts. Although we were especially interested in the fate of cases that a reviewing court remands to the initiating agency for further proceedings, we anticipated that such a study conld also be designed to generate data bearing upon a number of other important, albeit subsidiary, features of administrative law.

In the course of our study, we have coine to appreciate all too well how problematic such researcli mevitably inust be. The government does publislu data on the number, type, and judicial disposition of the administrative cases that are appcaled to the federal courts. ${ }^{11}$ But those data, although useful, are too highly aggregated to answer most of the more specific questions that we hoped to answer. We therefore were obliged to gather our own data in ways that are described below im Part II, and we consoled ourselves witl the conviction that on questions of this importance and interest, even inperfect information is better than perfect ignorance.

Our report is divided imto four parts. In Part II, we describe our study design, organizing the discussion around our four principal goals and explaining the specific procedures that we used to pursue each of them.

We present our findings and analysis of the $1965,1975,1984-85$, and 1988 data in Part III. We organize this discussion in four general sections. In the first two, we emphasize certain changes that oceurred in administrative law during the twenty years betwecn 1965 and 1985 . These changes relate to the style of appellate court opinions and the out-

11. Data on administrative cases brought before the federal courts can be found in the ANNUAL RePORT OF THE DIREctor OF THE ADMINISTRative OFFICE OF THE U.S. Courts (published jointly with Reports of the Proceeding of The Judicial Conference of the UNIted STATES). 
comes and certain structural features of judicial review of agency cases (what we call the "ages of administrative law"). In the third section, we draw upon data gathered for 1984-85 and 1988, focusing on how the Supreme Court's decision in Chevron U.S.A., Inc. v. NRDC, 12 affected the patterns of appellate court remands to agencies and considering whether those effects had dissipated by 1988, almost four years after Chevron was decided. In the fourth section, we analyze a crucial question that has received virtually no attention from commentators: What actually happens to remanded cases after they are returned to the agencies?

In Part IV, we distill the major conclusions of our study. We begin by offering some observations about the strengths and limitations of our general methodological approach as a tool for identifying and understanding changes in the patterns of court decisions. We then summarize our principal findings.

\section{Objectives AND Study Design}

We began our study with four principal objectives in mind. First, we hoped to describe the general parameters of judicial review of federal administrative action. Although we recognize the diversity of agencies, agency actions, reviewing courts, and judicial dispositions of agency cases, we attempted to render that diversity manageable by focusing our attention upon some broad categories of inforination. For example, we wanted to establish the number of agency decisions that are reviewed by the courts of appeals; the proportion of those cases that are affirmed, reversed, and remanded by the courts; the frequency witlı which cases are remanded for particular reasons; and the distribution of these variables among the different federal agencies and courts of appcals. At the same time, we lioped to shed hight upon some ancillary, but potentially interesting attributes of judicial review of agency decisions, such as the length and footuoting of judicial opimions, the number of sphit decisions, the size of appellate panels, the type of agency proceeding being reviewed, and the frequency with which the courts applied different standards of review. To that end, we decided to read a large, ${ }^{13}$

12. 467 U.S. 837 (1984).

13. The total number of cases in our 1965-1985 sample is 2325 , consisting of 372 decided in 1965,277 decided in 1974-75, and 1676 decided in 1984-85. The number of cases in our 1988 sample is 147. The grand total, therefore, is 2472 cases. The datasets, and the reasons for constituting them as we did, are explained infra text accompanying notes 16-32. 
representative ${ }^{14}$ sample of opinions in which federal courts of appeals engaged in direct review ${ }^{15}$ of agency action.

Second, we hoped to reveal some of the dynamic patterns of administrative law by gathering these kinds of data for cases decided over a period of time that would bracket the two decades, 1965 to 1985, during which judicial review of agency action, by most accounts, experienced fundamental conceptual and doctrinal changes relating to issues of standing, reviewability, standard and scope of review, and other basic issues. ${ }^{16}$ We therefore decided to read opinions rendered during five discrete time periods. Four of thein were six-month periods: in 1965, just before this transformation of judicial review is thought to have begun; in 1974-75, at a inid-way point during that twenty-year period; in 1984, after the transformation was thought to have concluded and just before Chevron was decided; and in 1985, after the Supreme Court reaffirmed and clarified Chevron. The fifth time period covered two inonths in early 1988, which was selected in order to learn whether the changes observed during the 1984-85 period had endured.

The 1984-85 period has the virtue of being close enough to the present to reficct the current state of administrative law (at least as revealed by our data), while also being distant enough from the present to facilitate our third objective-revealing what actually happens when appellate courts reinand eases to federal agencies for further proceedings. For this purpose, it was necessary that enough tine had elapsed since the reinand so that the vast majority of remanded cases could have reached their conclusions in order for us to analyze them as part of our dataset. ${ }^{17}$

14. Our sample included cases from each of the 16 appellate courts (the D.C. Circuit, the 11 numbered circrits, the Court of Claims, the Court of Customs and Patent Appeals, the Federal Circuit, and the Temporary Einergency Court of Appeals) that heard direct appeals from executive branch agencies during the period under study. A list of the agencies, together with their codimg keys, is appended as Appendix A.

15. We excluded all cases, such as Social Security Act adjudications, that had come to the courts of appeals through the federal distriet courts or through specialized judicial tribunals such as the U.S. Tax Court.

16. See, eg., Stewart, The Reformation of American Administrative Law, 88 HARv. L. REv. 1669, 1670 (1975) (noting that during this period, the Supreme Court had largely eliminated the standing barrier to challenges of agency action in court and that judges had accorded interest groups the right to force the initiation of formal agency proceedings).

17. When we ended the data collection in early 1988, two categories of rennanded cases remained incounplete: (1) those in which the lawyers had not provided all of the necessary information during the initial and follow-up interviews, and (2) those that had still been "open" (i.e., post-remand activity was still ongoing) at that point. In an effort to include these cases in our dataset, we made one final pass at them in August 1988, well after we had begun our preliminary data analysis. Even at that late date, some three to five years after the remand, we found that a certain number of cases remained in one or both of these categories. We dropped these from the dataset, at least as far as our analyses of post-remand events and evaluation of outcoines were concerned. 
In order to learn what had transpired after each of the roughly 180 cases during the 1984-85 period was remanded by a court of appeals to the agency for further proceedings, we conducted interviews by telephone (and occasionally in person) with the lawyer who represented the agency and with the lawyer who represented the petitioner. ${ }^{18}$ Those interviews were designed to elicit data bearing upon two "facts" that could not always be resolved by attempting to imtegrate the lawyers' differing perceptions-the specific post-remand events (about which there was seldom much disagreement between the opposing lawyers), and the parties' evaluation of the outcomes (about which disagreement was nore common). ${ }^{19}$

Our final objeetive explains why we defined and divided the 1985 period as precisely as we did. By doing so, we hoped to learn how the Court's Chevron decision, as clarified and reaffirmed eight months later in Chemical Manufacturers Association v. NRDC, ${ }^{20}$ had affected appellate court review of agency action. We discuss the changes in legal doctrine wrought by Chevron im more detail subsequently; ${ }^{21}$ for the inoment it suffices to say that in Chevron, the Supreme Court sent a strong signal to the courts of appeals that they should be more deferential in reviewing interpretations of statutes by administrative agencies. Even before we initiated our study, Chevron had occasioned a great deal of published commentary. Most of these commentators viewed (and often denounced) the deeision as a watershed administrative law ruling that would encourage reviewing courts to defer to agency interpretations and policy direetions. If true, this change would slow, if not reverse, the trend toward more intrusive judicial review that had gathered force during the preceding two decades. 22 In order to test the accuracy of these

18. At the written request of the ACUS, each federal agency identified a contact person within the agency (usually in the general counsel's office) who would help to facilitate the data-gathering for the study. The identity of the agency's and petitioner's lawyers often was obtainable from the published opinions, as well.

We generally sought to interview the most junior lawyer listed. Our assumption that this would be the lawyer closest to, and most knowledgeable about, the details of the case generally proved to be correct. Sometimes, of course, the lawyers who were in the best position to answer our questions were no longer employed by the agency or firm. In those cases, the interviewer attempted to locate that lawyer, and when that effort failed, the interviewer almost always was able to obtain the desired information from someone else in the agency or law firm who was (or after reviewing the file could become) familiar with the matter.

19. We explain how we handled this problem infra Part III(D), "What Happens After Remand?"

20. 470 U.S. 116 (1985).

21. See infra Part III(C), "Remands and the Chevron Effect."

22. See infra Part III(B)(1), "The Outcomes of Judicial Review." 
predictions, we read cases covering the six-month period preceding Chevron and the six-month period following Chemical Manufacturers. ${ }^{23}$

For purposes of managing and analyzing our dataset, we initially divided it into seven subsets of cases, each with its own computerized data file. These seven files were: (1) the 1965 cases (remand and nonremand);24 (2) the 1974-75 cases (remand and non-remand); ${ }^{25}$ (3) the 1984 non-remand cases (those which an appellate court had disposed of without remanding them to the agency); (4) the 1984 remand cases (those which an appellate court had, in the first instance, reinanded to the agency for further proceedings); ${ }^{26}$ (5) the 1985 non-remand cases; (6) the 1985 remand cases; ${ }^{27}$ and (7) the 1988 cases. $^{28}$ To facilitate those analyses for which the distinctions between remand and non-reinand cases, or between pre-Chevron and post-Chevron cases were not relevant, we then aggregated the 1984 and 1985 cases by creating (8) a inerged file of all 1984 cases; (9) a merged file of all 1985 cases; and (10) a file further coinbining all these merged files. These ten files contained data that had been generated in two ways: by analysis of the published opinions (froin all 1965 and 1974-75 cases as well as the 1984-85 non-reinand cases), and by opinion analysis plus subsequent telephone interviews (for the 1984 and 1985 remand cases).29

The 1676 appellate cases from the 1984-85 period that we analyzed were generated in the first instance by almost fifty different administra-

23. Although this means that we actually read cases covering five time periods, we treat the two six-month periods during 1985 as a single time period for purposes other than that of analyzing the effects of Chevron.

24. The 1965 sample covered cases decided during the six-month period between January 1, 1965 and June 30, 1965.

25. The $1974-75$ sample covered cases decided during the six-inonth period between October 15, 1974 and April 15, 1975. The latter date was selected as the cut-off date in order to immediately precede the Supreme Court's decision on April 16, 1975 in Train v. NRDC, 421 U.S. 60 (1975), a case that anticipated Chevron in mandating deference to agency constructions of statutes.

26. The 1984 sample (both non-remand and remand cases) covered cases decided during the six-month period between December 25, 1983 and June 25, 1984, the day Chevron was decided.

27. The 1985 sample (both non-remand and remand cases) covered cases decided during the six-month period between February 28, 1985 (the day after Chemical Manufacturess was decided) and August 31, 1985.

28. The 1988 sample covered cases decided during the two-month period between March 1, 1988 and April 30, 1988.

29. These data had been recorded by the researchers on individual coding sheets, one for each case. The final coding sheet, whicb is reproduced as Appendix B, differs from several earlier versions, but only slightly. The changes were made m order to: (1) add some items of information that could be adduced entirely from analysis of the published opinions (e.g., item AA relating to the standard of review); (2) refine some of the data categories (e.g., item $\mathrm{K}$ relating to the number of judges; item N relating to the result code); (3) correct obvious errors; and (4) permit computer programming. A coding key also was prepared to facilitate the uniform coding of the data. 
tive agencies. ${ }^{30}$ Among other things, we hoped to learn whether different agencies generated different patterns of appellate review and handled remands differently. We found it useful to group the agencies analytically for two reasons. First, a relatively few agencies accounted for a high proportion of the eases studied, whereas the great majority of agencies produced very few. ${ }^{31}$ Thus, analyzing the agencies individually often would preclude statistically significant findings, while grouping them into larger clusters might avoid this problein. Second, we beheved that certain groupings would help us to discern broad patterns that might otherwise remain obscured. Accordingly, we allocated each agency in our dataset to one of nine agency groups. ${ }^{32}$

The ease analyses, interviews, and data recordation were performed under our supervision from early 1987 to March 1989 by a group of law students at Georgetown and then at Yale, each of whom had completed a basic course in administrative law. ${ }^{33}$ Once the data had been gathered,

30. The number of agencies was smaller during the two earlier periods covered by the study, partly because fewer appellate cases were decided during those periods and partly because there were fewer agencies at that time. Because of the temporal parameters of our dataset, some relatively lowvolume agencies (e.g., the Consumer Product Safety Commission) do not have any cases in the dataset.

31. Three sources of agency cases-the Merit Systems Protection Board (MSPB), the National Labor Relations Board (NLRB), and the Immigration and Naturalization Service (INS) (sometimes through the Board of Immigration Appeals)-together accounted for approximately 57\% of the cases decided during the 1984-85 study period. Before the creation of the MSPB in 1978, the NLRB generated the most cases, accounting for $31.7 \%$ of the total in 1965 and $41.5 \%$ in 1975 .

32. We formed these groups and assigned particular agencies to them on the basis of a combination of analytical criteria and the frequency with which certain agencies appeared in our dataset. The groups are: (1) the National Labor Relations Board; (2) health, safety and environment regulatory agencies; (3) other regulatory agencies; (4) the Immigration and Naturalization Service and the Board of Immigration Appeals; (5) the Merit Systems Protection Board, which by far accounted for the largest number of cases (27.5\% in the 1984-85 period); (6) the Department of Labor; (7) executive departments other than the Department of Labor; (8) the Patent Office; and (9) all other agencies. The agencies included in each group are listed in Appendix A. These designations are arbitrary in the sense that they represent only one of the many ways in which the caseload could lave been sliced. The labels used for some of these groups are also crude. Thus, for example, the Federal Mine Safety and Health Review Commission, and the Occupational Safety and Health Review Commission, which are included in group (2), are not really regulatory agencies. Furthermore, although the Federal Aviation Administration and the Occupational Safety and Health Administration certainly fit well in this group, we coded them instead to the Departments of Transportation and Labor, respectively.

33. We took a number of precautions to satisfy ourselves that the students' analyses of the published opinions and their coding of the data were reasonably accurate and uniform.

Most of the data collected from the published opinions was objective and straightforward in nature and there was little risk of error. Only two pieces of data in the opinions required some exercise of judgment in coding: the type of agency proceeding (item $M$ on the coding sheet) and-a Inore difficult characterization-the reasons for remand (item $\mathbf{N}$ ).

In order to achieve a high level of uniformity in characterizing the type of agency proceeding, we reviewed with the students the differences between adjudication, rulemaking, and ratemaking, and discussed the kinds of agency actions that inight fall into the "other" category. We then in- 
coded, and error corrected, they were entered into a computer and preliminarily analyzed.

We, like all teachers and practitioners of administrative law, did not come to the subject without preconceptions. Indeed, we began our work with a variety of beliefs about what we would find and expectations that ranged froin weak intuitions to firm convictions. These formed the basis for a number of preliminary hypotheses concerning a range of administrative law phenomena that we hoped our results would illuminate. Most of these hypotheses-and certainly the inore important ones, from our point of view-relate to judicial reinands. They concern, for example, how court size, agency type, proceeding type, and other such variables affect reinands; low agencies respond to various kinds of remands; low long different administrative proceedings take to complete; and how

structed each of the students to read a random sample of cases, classify the type of agency proceeding involved in each, and bring any disputed classifications to us, whereupon we met as a group and resolved the few disputes in a way that further clarified the categories for the students.

Characterizing the reasons for remands was more difficult and we therefore felt obliged to be even more circumspect. First, we instructed all students to rcad a classic article by the latc Judge Henry Friendly elaborating the taxonomy of remands that we had found useful and wished to employ in the study. See Friendly, Chenery Revisited: Reflections on Reversal and Remand of Administrative Orders, 1969 DUKE L.J. 199. We then discussed that taxonomy as a group at some length. Before permitting the students to read any of the cases to be covered by the study, we asked each of them to read and to complete coding sheets for an identical random sample of cases. They were then to meet among themselves to discuss any instances in which soine or all of them had classiffed differently the reasons for a particular remand. After that, we inet as a group to discuss those differences as well as any uneertainties that remained. We also encouraged the students to raise with us any questions that might arise when they analyzed the cases covered by the study, and we resolved those questions in weekly meetings that both of us and all of the students (with occasional exceptions) attended. After the students had coinpleted all of the case analyses and coding sheets, we asked a lawyer with extensive administrative law experience in a federal agency to review for accuracy each of the cases and the students' coding sheets, making changes where appropriate. In addition, we reviewed each of the cases and coding sheets as to which the lawyer had raised any question, and we made the appropriate changes.

The authors adopted two additional rehability checks that should be standard procedure for studies of this kind. First, we each read several volumes of the Federal Reporter and checked our codings of the cases against those that the research assistants had compiled, going over any discrepancies with them in order to resolve any apparent misapprehensions. Second, we generated a list of key words and phrases that could be the basis for a computerized search for the cases that should be in our datasets. We then tested the reliability of this search technique by comparing its outputs to the cases contained in the relevant volumes of the Federal Reporter, enabling us to refine further the list of key words and phrases. Because this technique holds much promise for future research of this kind, we describe it in some detail in Appendix C.

Coding the data generated by the telephone interviews usually required only that the students accurately transcribe what the lawyers told them, not that they exercise independent judgment. The opposing lawyers seldom told them inconsistent things and when they did, the students simply recorded those differences on the coding sheet.

Given the large number of cases in the dataset and the limited experience of the students, we suspect that even these precautions failed to detect some errors. Nevertheless, we behieve that the number of such errors cannot be large enough to affect the general conclusions that we have reached from our analysis. 
these relationships have changed over time. Our dataset, however, also enabled us to cast some hight upon the evolution of certain other features of administrative law. These features, which are not specific to judicial remands, include the "style" of judicial opinions and soine of the imstitutional structures within which administrative law is generated. When we discuss our findings and analysis in Part III, we briefly note these hypotheses and our reasons for initially viewing them as plausible.

Before proceeding to a discussion of the findings and analysis, we wish to emphasize what the earher description of our methodology should have made clear: Much of our data is in aggregated form. To be sure, we have disaggregated it im inany forms-by agency, circuit, proceeding type, court size, time period, and disposition on appeal (itself broken down into several categories and subcategories). Still, our classification of the cases remains aggregated in some respects and irreducibly inipressiomistic. Its analytical categories are gleaned from the face of the opinions themselves, from the content of those opinions, or (in the case of the discussion of post-remand events) from information obtained from lawyers. We are acutely aware that these variables do not capture all, or even most, of the factors that explain why reviewing courts and agencies decide as they do. The list of other factors that also powerfully shape their decisions would surely be a long one. It would certainly include the following elements: the politieal environment in which the agency operates; the quality of the agency's persomiel and lawyermg, as well as the resources of private parties challenging the agency; the legal culture surrounding the agency; the respect with which the agency is held by hitigants and reviewing courts; the agency's techirical competence; the agency's statutory framework; and other similar factors. ${ }^{34}$

Although identifying such factors unquestionably would help one to predict and to explain agency and reviewing court behavior, we do not discuss them much here because they are tangential to our purposes. Our intention has not been to analyze the behavior of particular agencies or reviewing courts (although we have devoted some attention to trends in the D.C. Circuit). Instead, our purposes have been to uncover broad patterns and general trends in administrative law and, with respect to our discussion of Chevron, to gauge how an unusually controversial administrative law decision of the Supreme Court actually has affected reviewing

34. To cite just one example, Professor Linda Hirshman notes that the fact that NLRB orders have no effect until they are enforced by a circuit court "creates a culture among labor lawyers of considering all NLRB orders as very tentative, [which] would have a big effect on the statistics throughout [this study]. They should be resisted much inore often and reversed . . more often." Letter from L. Hirshman to E. Donald Elliott (Jan. 18, 1990) (available from authors). 
court (and, indirectly, agency) behavior. Our data, we think, are fully appropriate to those goals.

\section{FIndings and ANALYSIS}

Our findings can be analyzed usefully under four rubrics, which organize the four sections in Part III. In the first, "The Changing Style of Appellate Opinions," we consider the ways in which judicial opinions have changed between 1965 and 1985. In particular, our data permit us to describe (1) the role of "table decisions"; (2) patterns relating to the length and footnoting of opinions; and (3) the fraginentation of decisions by reviewing courts as reflected in the filing of separate opinions. Our purposes in this section are not merely descriptive; the data also shed light upon various hypotheses about some larger themes and underlying trends in administrative law.

In the second section, "The Ages of Administrative Law," we consider how certain structural and behavioral features of administrative law changed between 1965 and 1985. These features include: (1) the outcomes of judicial review; (2) the types of agency proceedings subject to judicial review; (3) the agency composition of the administrative law caseload in the circuit courts; (4) the size and distribution among circuit courts of that caseload; and (5) the composition of the reviewing courts.

In the third section, "Remands and the Chevron Effect," we consider the patterns of reviewing courts' deeisions to remand cases to the agencies. In particular, we (1) describe these patterns according to agency, circuit court, and type of reinand; (2) analyze whether and to what extent the Supreme Court's Chevron decision in 1984 affected the circuit courts' disposition of cases in general and their use of particular kinds of remands in particular; (3) discuss whether these effects persisted into 1988; and (4) analyze the effects on particular agencies.

In the fourth section, "What Happens After Remand?," we consider how agencies respond to remands and how those remands affect the outcome and duration of agency cases. The data that we present there are undemably inipressiomistic and subjective. Nonetheless, we are aware of no other systematic effort to imquire into these obviously crucial questions.

\section{A. The Changing Style of Appellate Opinions}

Between 1965 and 1985, administrative law became more coinplex and technical. The number of administrative agencies and circuit courts proliferated. American society became inore diverse and thus more difficult to regulate. Agency statutes iniposed more detailed substantive and 
procedural requirements. Rulemaking joined adjudication as a prominent mode of agency decisionmaking. The records compiled in the agency proceedings became longer and more technical. An ethos of public participation led to the expansion of traditional judicial remedies against agencies and the creation of new ones. ${ }^{35}$ The shecr volume of cases rose substantially, necessitating more judges and burdening court dockets. This larger body of precedent, lowever, settled relatively few issues; as is often true, judicial decisions tended to raise as many questions as they answered.

Of all the clianges in the landscape of administrative law over the past two decades, perliaps tlie most dramatic is the growing caseload. The number of administrative law cases decided on the merits by the federal courts of appeals lias risen steadily, more than tripling over two decades, from 489 cases in 1965 to more tlian 1567 cases in 1987. (See Chart 1.)

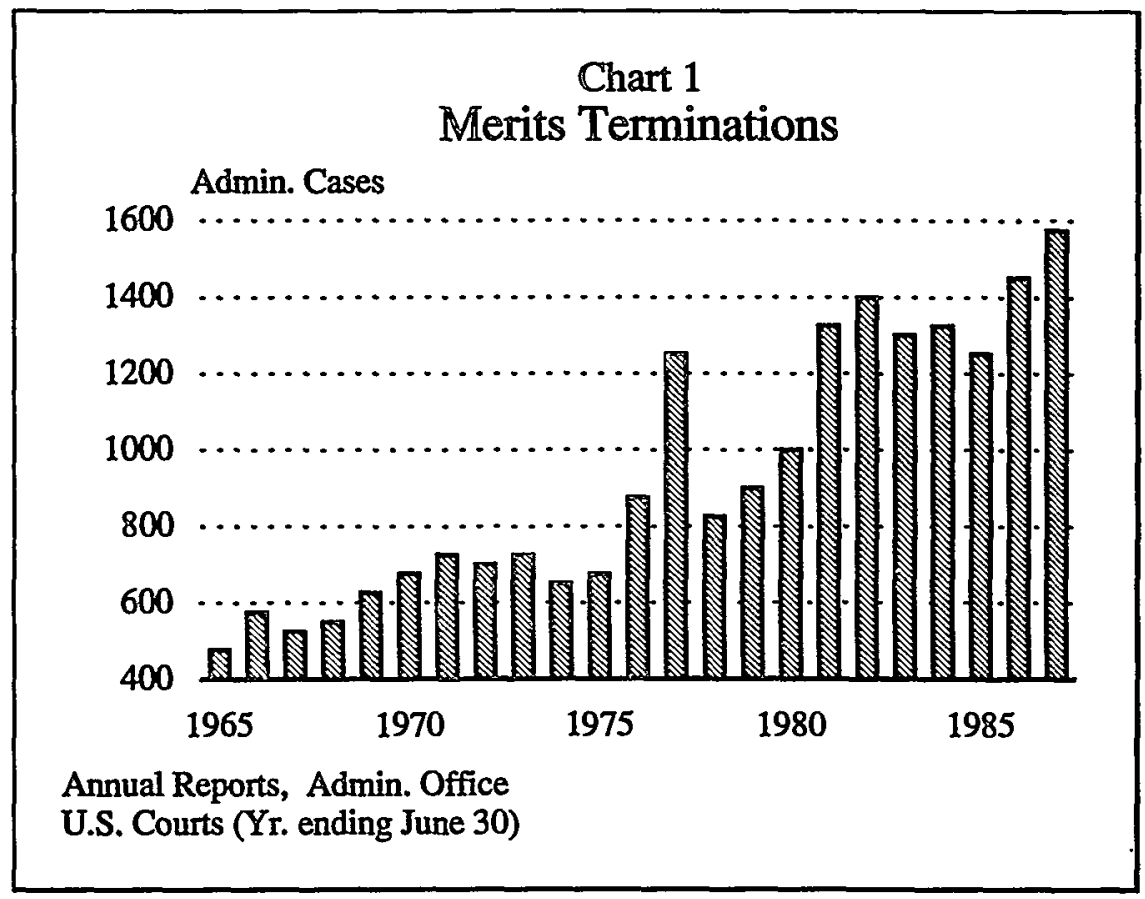

The number of appeals from administrative action filed in the federal courts of appeals lias grown by a similar proportion, also almost tripling between 1965 and 1985, from 1106 cases filed annually in 1965 to

35. See S. BReyer \& R. SteWART, ADMinistrative LAW AND REgulatory Policy 35-40 (2d ed. 1985). 


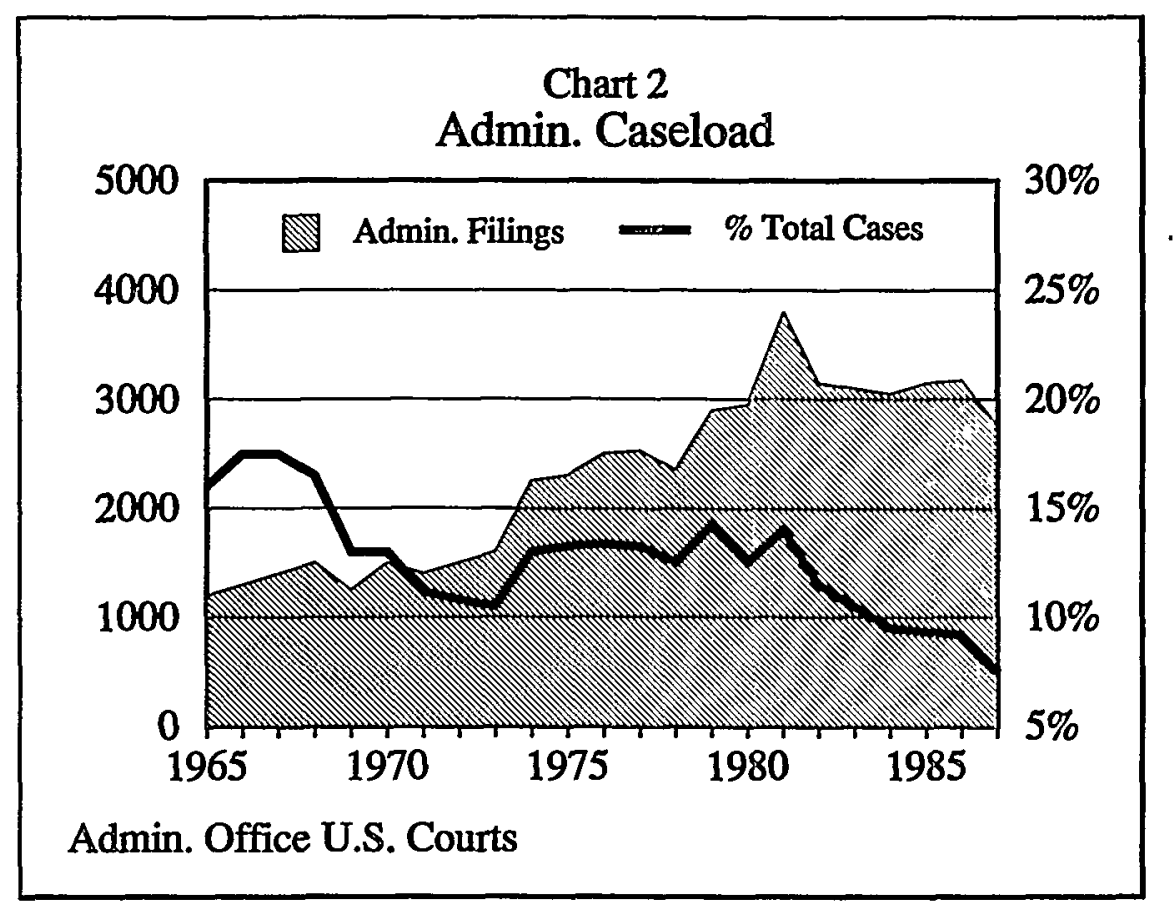

3179 filings in 1985. (See Chart 2.) Although the growth in the administrative caseload has indeed been dramatic, its effect should not be overstated. During the same period, the caseload of the courts of appeals in other areas grew even inore rapidly. Thus, despite substantial growth in the absolute number of direct appeals from administrative action, those cases actually constitute a inuch smaller percentage of the total business of the federal courts of appeals today than they did just two decades ago. Administrative appeals coinprised only about 7\% of filings in the courts of appeals in 1987, less than one-half of the $16 \%$ of the caseload that they accounted for in 1965. (See Chart 2.)

In short, two trends that inove in opposite directions are at work simnltaneously. The total body of administrative law is increasing rapidly, but administrative law appeals constitute a very sinall and evershrinking portion of the workload of individual circuit judges. The coinbination of these two factors raises serious questions about the opportunity for appellate judges today to develop substantial experience in handling administrative law cases. ${ }^{36}$

36. The D.C. Circuit and the Federal Circuit are striking exceptions to these generalizations: Administrative law appeals continue to comprise a significant fraction of their caseloads, thus permitting their members to acquire and maintain administrative law expertise. See infra text accompanying notes 79-84. 
These changes were bound to affect the ways in which appellate judges went about deciding agency cases. But it was not at all obvious precisely how they would adapt to the more complex disputes that incrcasingly arose before them. Some responses were readily predictable. Other things being equal, for example, busy judges needing to dispose of a larger caseload would probably employ more panel and fewer en banc decisions.

But other responses were less certain because the pressures for change sometimes pushed the courts in conflicting directions. On the one hand, for example, one might suppose that judges pressed for time would feel constrained to write shorter opinions. On the other hand, one might also anticipate that the presence of more complex cases would make it more difficult for the judges to secure agreennent among themselves. Similarly, their need to accommodate diverse views, coupled with the analytical demands posed by massive, technical administrative records, would lead them to write longer opinions, file more separate ones, and use more footnotes. The growth in the number of judicial clerks during this period might also encourage these developments.

We expected that these competing tendencies would be particularly strong in several situations: (1) in the D.C. Circuit, whose administrative law caseload is larger and is generally considered to be both more complex and more controversial than those of the other circuits; ${ }^{37}$ (2) in rulemaking and ratemaking proceedings, which are usually inore farreaching than adjudications and generate more extensive, techirical administrative records; (3) in en banc proceedings, which involve more judges and tend to be reserved for the most iniportant cases; and (4) in cases involving health, safety, and enviroumental agencies, which also often generate extensive, techircal records and are politically controversial. As we shall discuss in later parts of this section, our data bear out some of these expectations, but not others.

1. Table Decisions. Even before we began our analysis of the data, one development fairly leaped off the pages of the Federal Reporter. For many of the administrative law (and otler) cases decided by the cir-

37. See, e.g., Robinson, The D.C. Circuit: An Era of Change, 55 GEo. WASH. L. Rev. 715, 716 (1978) (one-fourth of all federal agency reviews reach the D.C. Circuit, far more than in any other circuit); The Contribution of the D.C. Circuit to Administrative Law, 40 ADMIN. L. REv. 507 (1988) (transcript of a program presented at the ABA Section of Administrative Law Fall meeting in October 1987 on the special and increasing significance of the D.C. Circuit as the ultimate decisionmaker for most agency decisions; in 1986, the D.C. Circuit received $30 \%$ of all agency appeals). This view is buttressed by statutory provisions locating venue for certain types of important disputes in the D.C. Circuit. E.g., 42 U.S.C. § 7607(b)(1) (1988) (challenges to nationally applicable Clean Air Act regulations). 
cuit courts, the Reporter publishes "table decisions" containing only minimal information: the names of the lead petitioner and respondent; the docket number; the date and disposition of the appellate court decision; and the forum (agency or court) from which the appeal was taken. Depending upon the local rules of particular circuits, the courts that issue these "table decisions" may or may not provide brief memoranda opinions to the parties, but these memoranda are not published in the $R e$ porter. ${ }^{38}$ Thus, if one looks only at the information published in the table decision itself, one can learn neither the nature of the dispute nor the reasons supporting the disposition. The opacity of these table decisions and the courts' increasing resort to this practice have received some critical cominentary during the recent years when its use has grown most rapidly. ${ }^{39}$ The use of table decisions is an important phenomenon that raises fundamental questions about judicial practice and legal process. ${ }^{40}$ These questions deserve detailed consideration, but most of them are outside the scope of this project.

During the period covered by our study, these table decisions have come to dominate appellate courts' disposition of all types of eases, including those arising from administrative agencies. The origins of the

38. In the mid-1980s, some of the circuits began providing memoranda and opinions underlying these decisions to WESTLAW and LEXIS.

39. See Reynolds \& Richman, An Evaluation of Limited Publication in the United States Courts of Appeals: The Price of Reform, 48 U. CHr. L. REV. 573 (1981) [hereinafter Reynolds \& Richman, An Evaluation]; Robel, The Myth of the Disposable Opinion: Unpublished Opinions and Government Litigants in the United States Court of Appeals, 87 Mrch. L. Rev. 940 (1989); Comment, Unreported Decisions in the U.S. Courts of Appeals, 63 CoRNell L. Rev. 128 (1978); see also Judge Wald's separate statement in National Classification Comm. v. United States, 765 F.2d 164, 172-75 (D.C. Cir. 1985); D. Stienstra, Unpublished Disposttions: Problems of Access and Use in the CoURTS OF APPEAls (1985); Ginsburg, The Obligation to Reason Why, 37 U. FLA. L. REv. 205, 218-23 (1985).

There also has been criticisn of rules in some circuits that permit a party to request publication of an opinion. E.g., Reynolds \& Richman, The Non-Precedential Precedent-Limited Publication and No-Citation Rules in the United States Courts of Appeals, 78 CoLUM. L. REv. 1167,1179 \& n.72 (1978). There has been somewhat more commentary on the impact of publication rules in particular circuits. See Reynolds \& Richman, Limited Publication in the Fourth and Sixth Circuits, 1979 DUKE L.J. 807 (analyzing the approaches of the Fourth and Sixth Circuits in limiting publication and evaluating the plan's efficiency in relation to the risks involved in nonpublication); Comment, $A$ Snake in the Path of the Law: The Seventh Circuit's Non-Publication Rule, 39 U. PrT. L. Rev. 309 (1977) (arguing that the federal circuit courts have attempted to promote judicial efficiency by introducing publication plans which permit some judgments without opimions).

For commentary on the impact of limited publication in state courts of appeals, see Andreani, Independent Panels to Choose Publishable Opinions: A Solution to the Problems of Colifornia's Selective Publication System, 12 PAC. L.J. 727 (1981); Newbern \& Wilson, Rule 21: Unprecedent and the . Disappearing Court, 32 ARK. L. REv. 37 (1978); Render, On Unpublished Opinions, 73 KY. L.J. 145 (1984-85).

40. In the D.C. Circuit, at least, unpublished opimions have no precedential effect except upon the parties to that hitigation. See Mobil Oil Corp. v. EPA, 871 F.2d 149, 150 n.1 (D.C. Cir. 1989). 
practice of disposing of appeals via unpublished orders or short, unpubhished memoranda are somewhat murky. In 1964, the Judicial Conference of the United States formally endorsed the practice in a recommendation that the federal courts should authorize "the publication of only those opinions which are of general precedential value."41 By 1965, a significant number of administrative law cases probably were disposed of by unpublished order or opinion. Unfortunately, we have been unable to determine exactly how many unpublished dispositions occurred in 1965, because at that time the Federal Reporter gave no indication that cases had been disposed of by unpublished order or meinorandum. Between 1966 and 1974, each of the circuits promulgated a circuit publication plan, and in 1972 West Publishing Co. began to publish tables in the Federal Reporter listing the cases that had been disposed of by unpublished order or memorandum, in what we call "table decisions." ${ }^{42}$ In 1974, the Judicial Conference approved each of the circuit's publication plans, which varied in regard to both publication criteria and citation rules. ${ }^{43}$

The practice of disposing of cases through table decisions caught on quickly. In our 1975 sample of cases, almost $29 \%$ were table decisions. A decade later, almost $60 \%$ of our (1nuch larger) sample were table decisions. (See Cliart 3.) Indeed, the nrove toward using table decisious rather than published opinions to decide the bulk of their cases inay well have been the courts' major imstitutional response to their burgeoning caseload. This developnent also parallels (and presumably interacts with) a trend toward longer published opinions. Table 1, which follows, displays the differences in outcomes between published opinions and table cases. ${ }^{44}$

41. Reynolds \& Richman, An Evaluation, supra note 39, at 577 (quoting THE REPORT OF THE Judicial CONFERENCE OF THE UNITED STATES 11 (1974)).

42. 467 F.2d 943-44 (1972). In this connection, West exercises no discretion, but simply includes in the tables all decisions that are submitted to it by the circuits for publication.

In 1973, the Advisory Colmcil for Appellate Justice of the Federal Judicial Center publislred Standards for Publication of Judicial Opinions, whicls urged that eacli impublished opinion should contain the results and reasoning and explain the results to the appellate court in order to facilitate review. Advisory Council on Appellate Justice, Standards for Publication of Judicial OpINIONs (Researcli Series No. 73-2) (1973).

43. Although this diversity was viewed as a source of useful experimentation, the Conference has not subsequently reexamined the issue. THE REPORT OF THE Judicial CONFERENCE OF THE UNITED STATES 12-13 (1974).

44. It sliould be noted that the numbers and percentages of cases presented in Table 1 and in subsequent tables and in the text may reflect some double counting, as when a case was coded both "affirmed in part" and "other." As the tables indicate, the frequency of such double connting was very low. For this reason, we are confident that sucl double connting did not significantly affect any of the findings that we report. 


\section{Chart 3 \\ Unpublished Decisions}

Opinion

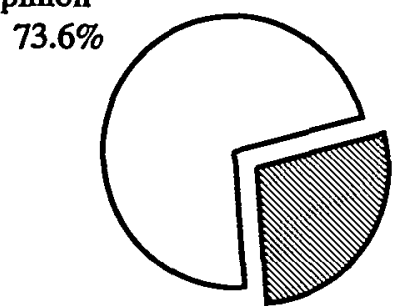

1975

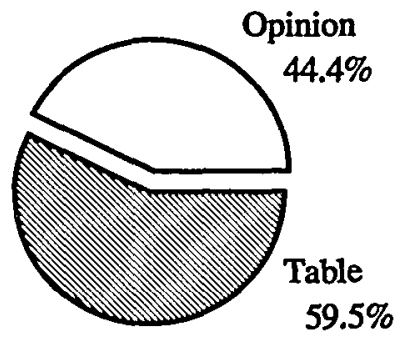

$1984 / 85$

\section{Percentage of Table Cases}

For much of the analysis that follows, it matters a great deal whether table decisions are or are not included in the dataset. Because table decisions provide no information as to the court's reasoning, we expected that the overwhelming majority of these decisions would be affirmances and that there would be virtually no reversals or remands.

We were wrong. By the 1984-85 period, the courts' use of table decision dispositions had become so common that we found thirty-seven table decisions that were outright reversals and fifty-two that were remands to the agencies. These reversals constituted $3.7 \%$, and remands constituted 5.2\%, of the 997 table decisions contained in our dataset. Together, these eighty-nine cases represented $5.3 \%$ of all cases (opinions and tables) in our dataset for that period. In our 1988 sample, $4.8 \%$ of all cases were reversals and remands taking the form of table decisions. ${ }^{45}$

Because table decisions are used so frequently and are not confined to affirmances, we felt constrained to analyze much of the data in two ways-including and excluding table decisions. In reporting the results, then, we make reference to the effect of table decisions on the specific

45. According to one study, almost $25 \%$ of the circuit court decisions reversing, vacating, or denying a lower court decision werc unpublished; the figure for the Sixth Circirit was $41.9 \%$. D. STIENSTRA, supra note 39, at 42 (Table 3). 
Table 1: Outcomes-Opinion vs. Table Decisions

\begin{tabular}{lrrr} 
& \multicolumn{3}{c}{$\begin{array}{c}1965 \\
\text { Opinion }\end{array}$} \\
& \# & \multicolumn{1}{c}{ Table } & \\
\hline Affirmed & 205 & $55.1 \%$ & NA \\
Reversed & 107 & $28.8 \%$ & NA \\
Remanded & 51 & $13.7 \%$ & NA \\
Other & 10 & $0.7 \%$ & NA \\
Subtotal & 373 & $100.3 \%$ & \\
Total & 373 & $100.3 \%$ & \\
No. Cases & 372 & &
\end{tabular}

\begin{tabular}{|c|c|c|c|c|c|c|}
\hline & \multirow{2}{*}{\multicolumn{2}{|c|}{$\begin{array}{c}1975 \\
\text { Opinion }\end{array}$}} & & \multirow{2}{*}{\multicolumn{2}{|c|}{ All }} \\
\hline & & & & able & & \\
\hline & \# & $\%$ & \# & $\%$ & $\#$ & $\%$ \\
\hline Affirmed & 96 & $34.7 \%$ & 72 & $26.0 \%$ & 168 & $60.6 \%$ \\
\hline Reversed & 62 & $22.4 \%$ & 4 & $1.4 \%$ & 66 & $23.8 \%$ \\
\hline Remanded & 41 & $14.8 \%$ & 1 & $0.4 \%$ & 42 & $15.2 \%$ \\
\hline Other & 5 & $1.8 \%$ & 2 & $0.7 \%$ & 7 & $2.5 \%$ \\
\hline Subtotal & 204 & $73.6 \%$ & 79 & $28.5 \%$ & 283 & \\
\hline Total & 283 & & & & & $102.17 \%$ \\
\hline No. Cases & & & & & 277 & \\
\hline
\end{tabular}

\begin{tabular}{|c|c|c|c|c|c|c|}
\hline & \multicolumn{4}{|c|}{$1984+1985$} & \multirow{2}{*}{\multicolumn{2}{|c|}{ All }} \\
\hline & \multicolumn{2}{|c|}{ Opinion } & \multicolumn{2}{|c|}{ Table } & & \\
\hline & \# & $\%$ & \# & $\%$ & \multicolumn{2}{|r|}{$\%$} \\
\hline Affirmed & 402 & $24.0 \%$ & 884 & $52.7 \%$ & 1286 & $76.7 \%$ \\
\hline Rever & 146 & $8.7 \%$ & 37 & $2.2 \%$ & 183 & $10.9 \%$ \\
\hline Remanded & 141 & $8.4 \%$ & 52 & $3.1 \%$ & 193 & $11.5 \%$ \\
\hline Other & 55 & $3.3 \%$ & 24 & $1.4 \%$ & 79 & $4.7 \%$ \\
\hline Subtotal & 744 & $44.4 \%$ & 997 & $59.5 \%$ & 1741 & \\
\hline Total & 1741 & & & & & $103.88 \%$ \\
\hline No. Cases & & & & & 1676 & \\
\hline
\end{tabular}

variable where the results would appear to differ significantly depending upon whether they are included or excluded.

2. The Length and Footnoting of Opinions. In order to test certain hypotheses about the writing style of judicial opinions, the complexity of administrative law issues, and the degree of reviewing court fragmentation, we coded each opinion according to its length and number of footnotes. These two variables amount to very crude ${ }^{46}$ indices that could reveal any trends toward greater judicial prolixity, issue coin-

46. We have no doubt that superior indices could be used. The great virtue of ours, of course, is that they are easily measured and coded. This is an example of the unfortunate but inevitable reality that inethodological constraints often drive and shape the analysis. 
plexity, documentation of evidence, and precedential significance that might exist. Because we believe that these issues are of only secondary interest, we have decided to report our conclusions in summary fashion here; we present a more complete discussion of the data in Appendix D.

In brief, we found that the D.C. Circuit writes longer, more heavily footnoted opinions than the other circuits do; that this disparity has increased since 1975; that the average opmion among all circuits was much sliorter in 1985 than in 1975 if table decisions are included, and was about the same length if they are excluded; that rulemaking and ratemaking opinions are longer and more leavily footnoted than adjudication opinions; that (contrary to our expectation) law-based remands are generally shorter and less heavily footnoted than other kinds of remands; that (agaim, contrary to our expectation) en banc decisions are shorter and less heavily footnoted than three-judge court decisions; and that courts reviewing lealth, safety, and environmental agencies write longer, more leavily footnoted opinions than courts that review most other kinds of agencies.

3. The Fragmentation of Decisions. Our data seemed especially useful for testing the "increased divisiveness" hypothesis. Many observers-most notably the former Chief Judge of the D.C. Circuit herselfhave commented on the pronounced ideological shift that occurred on that court after the confirmation of three "conservative" Reagan appointees in 1982 and $1983 .{ }^{47}$ If these appoimtments did affect outcomes, then their effect might be captured in a comparison of our 1975 dataset, which preceded the appointments, witl our 1985 dataset, which followed the last of them by several months. ${ }^{48}$ More fundamentally, however, the divisiveness of a court may be defined im terms of its propensity to write separate opinions. ${ }^{49}$ In measuring this propensity, we wished to avoid

47. See Wald, Rebel Angel in Flight, District LAW., July/August 1986, at 30, 32; Pierce, Two Problems in Administrative Law: Political Polarity on the District of Columbia Circuit and Judiclal Deterrence of Agency Rulemaking, 1988 Duks L.J. 300, 303-17 (discussing ideology in the D.C. Circuit). Judges Bork, Scalia, and Starr were the Reagan appoiutees during the period preceding our 1984-85 dataset. But see Edwards, Public Misperceptions Concerning the "Politics" of Judging: Dispelling Some Myths About the D.C. Circuit, 56 U. Colo. L. REV. 619 (1985).

48. The last, Judge Starr, was appointed about three months before our 1984 case sample began, and the court's membership then remained unchanged until well after our 1985 sample ended.

49. For prior discussions of the issue of fragmentation and divisiveness in judicial opinions, see Easterbrook, Ways of Criticizing the Court, 95 HARV. L. REV. 802 (1982); Easterbrook, Agreement Among the Justices: An Empirical Note, 1984 SUP. CT. REv. 389. In analyzing divisiveness, we counted the number of separate opinions, which has the advantage of being an objective measure, but gives the same weight to concurring and dissenting opinions. Although in some cases dissents may reflect a greater degree of division on the court than concurrences, we believe that the number of separate opinions is the best measure of divisiveness. The ouly other possible ineasure of divisiveness that our data could exploit is the number of footnotes in the court's opinion(s). Because the 
several potentially distorting effects of including table decisions in our analysis, ${ }^{50}$ yet we did not wish to exclude them altogether. For if it is true that the more divided a court is, the less likely it will be to issue table decisions, then data on table decisions might enrich, rather than detract from, our analysis of divisiveness in different circuits and over time.

For similar reasons, we could not very well draw inferences about court divisiveness without considering the additional variable of court size. Simple logic strongly suggests that the number of judges who sit on a case is directly related to the number of opinions per case that will be written. This would be true, moreover, even if court size were not independently related to divisiveness-that is, even if the most controversial cases were not the ones most likely to be heard en banc.51 Our data confirm this relationship between the number of judges and the number of opmions per case; the correlation was present im all periods, and was especially strong in the most recent one. ${ }^{52}$

When we measure divisiveness (or its opposite, consensus) by the average number of opinions per case, we find (not surprisingly) that in all periods, the more divisive the case is, the longer and more heavily footnoted the opinions are..$^{53}$ When we analyze divisiveness nationally (that is, aggregating all circuits) and over time, and we exclude table decisions, we find that the proportion of one-opimion cases actually increased between 1965 and 1975 (from about $81 \%$ to $87 \%$ ) and then remained at

relationship between the number of footnotes and the degree of divisiveness is weak, ambiguous, and speculative, however, we simply mention it briefly here.

50. Because table decisions invariably involve only one opinion, courts' use of them operates to reduce the average number of opinions per case. This could produce distortion if, for reasons having nothing to do with divisiveness, their use increased over time or if different circuits use them in different proportions. In fact, different circuits do use table cases in different proportions, and those proportions have changed over time. In 1975, when $28.5 \%$ of the cases were table decisions, the major users of table decisions on a percentage basis were the First (75\%) and Fourth (64\%) Circuits, with four other eircuits (the Sixth, Seventh, Eighth, and the Court of Claims) clustering around $20 \%$. In 1984-85, when the proportion more than doubled to about $59 \%$, the frequency of use umong the circuits produced a very different pattern.

51. As we have just seen, court size does not always correlate with longer opinions and more footnotes. These findings are surprising, at least if one assumes that cases that courts schedule to hear en banc tend to be more divisive (a proposition that we believe, but on which we have no data) or more important, that more divisive and inportant cases produce longer and more heavily footnoted decisions (a proposition that we substantiate immediately below with respect to divisiveness, see infra note 53 and accompanying text).

52. In 1984-85, en banc courts wrote twice as many opinions per case as three-judge panels, a much higher ratio than in the previous time periods.

53. Perhaps more interesting - but limited by the small number of three-opimion cases in the samples-is the observation that the footnoting seems to increase geonnetrically as divisiveness grows from two to three opinions per case. In 1984-85, for example, one-opinion non-table cases (593) averaged six footnotes, two-opinion cases (86) averaged a total (for both opinions) of 10 footnotes, and three-opinion cases (ouly nine) averaged a total of $\mathbf{4 1}$ footnotes. 
essentially the same level in 1984-85. Since table decisions are almost by definition unanimous, and because their use has increased markedly over time, mcluding them in the analysis would greatly strengthen this already discernible trend toward inore consensus in the circuit courts (when those courts are viewed in the aggregate).

Viewing the D.C. Circuit in isolation does not really alter this conclusion; indeed, that court exhibits an even stronger trend toward greater consensus-at least through the period covered by our 1984-85 dataset. Excluding table decisions, the proportion of one-opinion decisions in the D.C. Circuit increased from about $70 \%$ in 1965 to over $75 \%$ in 1975, and then (contrary to the trend in the aggregated circuits) the rate further increased to almost $81 \%$ in $1984-85$. When we take table decisions into account, the consensus in the D.C. Circuit is even greater: In the 1984-85 period, $86.5 \%$ of its decisions involved only one opinion, whereas $13.5 \%$ involved two or more opinions (thrce tinies the percentage in all other circuits viewed in the aggregate). This trend becomes even more striking when it is understood that the D.C. Circuit's share of the national total of table decisions actually declined sharply between 1975 and $1984-85$-from over $27 \%$ to under $7 \%,{ }^{54}$ thus negating any possibility that the imclusion of table decisions (which are unanimous) inflated our consensus ineasure arbitrarily. ${ }^{55}$

Our data thus seein to refute the strong inipression among commentators that "pohitical polarity" 56 on the D.C. Circuit grew during the decade after 1975. It is true that consensus on that court has always been low relative to almost all other circuit courts; during all periods covered by the study, its consensus level was lower than the national average, which in the inost recent period was over $86 \% .{ }^{57}$ It is also possible that the court's divisiveness did increase significantly after 1984-85, when ad-

54. The lion's share of this decline in the D.C. Circuit's share of the national total between 1974 and 1984-85 was picked up by the Federal Circuit. In 1981, the Federal Circuit not only acquired the jurisdictions of the Court of Customs and Patent Appeals, and the Court of Claims, but also became the exclnsive venue for all patent appeals. In 1975, the shares of its two predecessor courts were only about $5 \%$.

55. The argument would be that a court's use of the table decision device, although largely signaling collegial consensus, might in soine cases be used purely as a way to enable an overburdened court to deal with caseload pressures. In those cases, so the argument would run, the unanimity of the table decision really reflects an exigent, artificial consensus, not a real one.

56. See Pierce, supra note 47.

57. The D.C. Circuit, however, was not the only court below the national average. During each period, there was at least one other circuit whose consensus level was either lower tlian or approximately the same as the D.C. Circuit's. In 1965, the First Circuit and the Court of Customs and Patent Appeals were in this position; in 1975, the Seventh and Eighth Circuits; and in 1984-85, the Third and Eighth Circuits. 
ditional Reagan appointees joined the court ${ }^{58}$ and several older Deinocratic appointees holding senior status, including Chief Judge David Bazelon, died or retired. ${ }^{59}$ All we can say with some assurance is that this increased divisiveness, if present at any time, was not observable in the $1984-85$ cases.

\section{B. The Ages of Administrative Law}

1. The Outcomes of Judicial Review. Before this study began, we believed (along with inost other administrative lawyers, we suspect) that judicial review of administrative action was deferential in the 1960s, that it became inore stringent during the "hard look" era in the 1970s, and then settled back to a inoderately deferential stance during the $1980 \mathrm{~s} .{ }^{60}$ We also shared the common behef that these putative trends would be exhibited inost conspicuously by the D.C. Circuit.

This picture of the "ages of administrative law" is now part of the shared professional culture of administrative lawyers. ${ }^{61}$ It is one of our shibboleths, a conventional truth that knowledgeable lawyers repeat to one another and teach the next generation. One goal of our study was to explore whether this conventional picture of the changing nature of judicial review was aceurate. We discovered that because of the distorting effect of table decisions, it was difficult to forin an aceurate judginent about even so fundamental an issue as the likelihood that appellate courts would overturn administrative decisions on judicial review solely by relying on the public record of decisions pubhished in the Federal Reporter.

That said, our analysis of published decisions from 1965, 1975, and 1984-85, as exhibited in Table 2, does show a consistent trend toward an increasing percentage of affirmances.

Chart 4 shows a long-term trend toward increasing rates of affirnanees by courts in administrative law cases, front $55.1 \%$ in 1965 , to

58. Judges Silberman, Buckley, Williams, Douglas Ginsburg, and Sentelle joined the court between 1985 and 1987.

59. Senior Judges McGowan and Bazelon, both Democratic appointees, and Senior Judges Robb and Wilkey, Republican appointees, left the court after 1985.

60. See, e.g., Elliott, The Dis-Integration of Administrative Law: A Comment on Shapiro, 92 YALE L.J. 1523, 1530 (1983) ("As an historical matter, the high-water mark of judicial control of administrative action was reached about a decade ago ... [in] the middle 1970's ....").

61. See, eg., S. BREYER \& R. STEWART, supra note 35, at 35-36. Breyer and Stewart argue: Basic public trust in the administrative process and the spirit of working partnership between agency and reviewing courts that had developed in the postwar period began to disintegrate after 1965 . The work of administrative agencies came under increasingly sharp attack on several fronts, and courts began to impose inore stringent and far-reaching controls on the administrative process.

See also Stewart, supra note 16, at 1712-13 (because agencies are biased in favor of clients and unresponsive to interest groups, courts have atteinpted to change the traditional model to clieck such biases). 
Table 2: OUtcomes-Chr Square Test

\begin{tabular}{lcrcc} 
& \multicolumn{2}{c}{1965} & & \\
& Observed & Percent & Expected & $(\mathrm{O}-\mathrm{E})^{2} / \mathrm{E}$ \\
\hline Affirmed & 205 & $55.1 \%$ & 258.16 & 10.95 \\
Reversed & 107 & $28.8 \%$ & 55.40 & 48.07 \\
Remanded & 51 & $13.7 \%$ & 44.50 & 0.95 \\
Other & 10 & $2.7 \%$ & 14.94 & 1.63 \\
Total & 373 & $100.3 \%$ & & \\
No. Cases & 372 & & &
\end{tabular}

\begin{tabular}{|c|c|c|c|c|}
\hline & & & & \\
\hline & Observed & Percent & Expected & $(\mathrm{O}-\mathrm{E})^{2} / \mathrm{E}$ \\
\hline Affirmed & 168 & $60.6 \%$ & 195.87 & 3.97 \\
\hline Reversed & 66 & $23.8 \%$ & 42.03 & 13.67 \\
\hline Remanded & 42 & $15.2 \%$ & 33.77 & 2.01 \\
\hline Other & 7 & $2.5 \%$ & 11.33 & 1.66 \\
\hline Total & 283 & $102.2 \%$ & & \\
\hline No. Cases & 277 & & & \\
\hline & 19 & +85 & & \\
\hline & Observed & Percent & Expected & $(\mathrm{O}-\mathrm{E})^{2} / \mathrm{E}$ \\
\hline Affirmed & 1286 & $76.7 \%$ & 1204.97 & 5.45 \\
\hline Reversed & 183 & $10.9 \%$ & 258.57 & 22.09 \\
\hline Remanded & 193 & $11.5 \%$ & 207.73 & 1.04 \\
\hline Other & 79 & $4.7 \%$ & 69.73 & 1.23 \\
\hline Total & 1741 & $103.9 \%$ & & \\
\hline No. Cases & 1676 & & & \\
\hline $\begin{array}{l}X^{2}=112.71 \\
{\left[6 \text { df: if } X^{2}>\right.}\end{array}$ & & & & \\
\hline
\end{tabular}

$60.6 \%$ in 1975 , to $76.6 \%$ in $1984-85$. There are corresponding decreases in the rates of reversals and remands. These data contradict the conventional wisdom, which would predict a higher rate of reversals and reinands in 1975 than in 1965 or 1984-85.

Based on an analysis of the opinions published in the Federal Reporter, we were prepared to conclude that the conventional wisdom was wrong: According to our data, judicial review was not more stringent in the iniddle-1970s, at least if by "stringency" one ineans the propensity of the courts to reverse or remand rather than affirm. Indeed, our data tend to understate affirmances and to overstate reversals and remands because we coded a case as a reversal or remand if it was reversed or remanded on any ground even if, as often occurs, the court affirmed on all but one or a few issues and those issues were relatively minor ones. Data from the Administrative Office of the U.S. Courts (AO) tell a different story than the data in Chart 4 generated by our analysis of the bound 


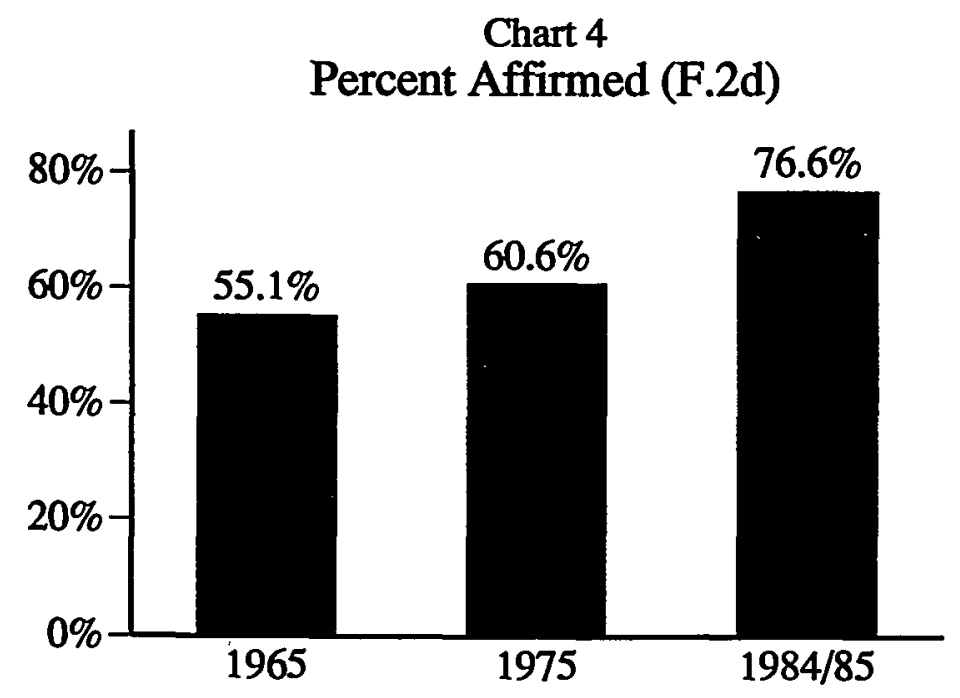

Percent of admin. cases affirmed in toto Data: This study of F.2d

volumes. ${ }^{62}$ Chart 5 shows the AO data for terminations of administrative law cases in the courts of appeals after hearing or submission for the same years that we analyzed in Chart 4.

The largest disparity between these two datasets is for 1965. For 1965 , we found only a $55 \%$ affirmance rate, whereas the AO data show a 75\% affirmance rate. For 1975, our figures were much closer: We found a $61 \%$ affirmance rate; the AO had a $70 \%$ affirmance rate. For 1984-85, we were in almost total agreeinent: Our affirmance rate was $76.6 \%$; the AO's was $75.9 \%$.

We think that these disparities largely reflect differences in the way that we and the $\mathrm{AO}$ defined and generated the datasets. We discuss these differences and their effects in Appendix E.

Strictly speaking, of course, the success rate of agencies in court says nothing about the "stringency" of judicial review. Outcomes in the reviewing courts are a function of (at least) two variables-how much courts are deinanding, and how well agencies are conforming to the dictates of the law. It is possible that today's courts are much more demanding than their predccessors of the 1960s and 1970s, but that

62. Professor Pierce, it should be noted, relies on the AO data for his assertions about the D.C. Circuit's propensity to reverse and remand agency actions. Pierce, supra note 47, at 302 n.13. 


\section{Chart 5 \\ Percent Affirmed (AO)}

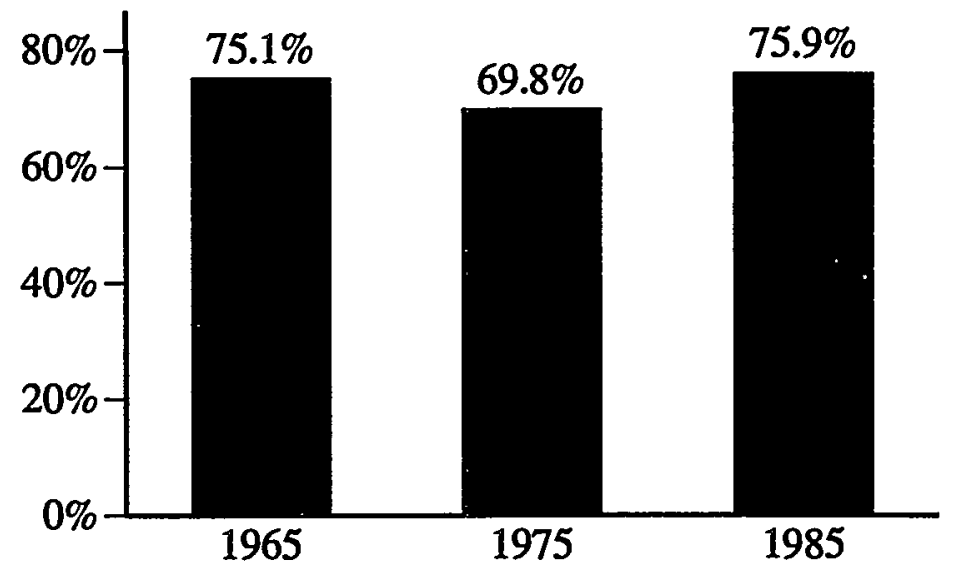

Percent of admin. cases affirmed in toto

Data: Administrative Office U.S. Courts

agencies have improved their performance even faster. Thus, agencies may be "out ahead of the curve" of increasingly stringent judicial review.

There is probably some truth to this reading of the data. In some areas, the law today is undemiably more demanding than it was in 1965. An example of this phenomenon is the Administrative Procedure Act's (APA) requirement that agencies provide notice and an opportunity for pubhic comment before changing a rule. ${ }^{63}$ In the 1960 s, agencies routinely published short, vague notices in the Federal Register that provided hittle information about the factual basis for their actions. 64 By the early 1970s, courts had begun to require more detailed disclosure of the underlying factual support for the agency's action, at least when there was no compelling necessity to dispense with the opportunity for public comment. ${ }^{65}$ Agencies responded by providing inore detailed disclosures in their published notices to meet the higher standards, and courts began once agam to uphold agency notice provisions. ${ }^{66}$ Today, courts seldoin

63. See 5 U.S.C. $\S \S 553(b)-(c)(1988)$.

64. See, e.g., J. Mashaw \& R. Merrill, Administrative LaW: The American Public LAW SYSTEM, CASES AND MATERIALS 450 (2d ed. 1985).

65. See, eg., Wagner Elec. Corp. v. Volpe, 466 F.2d 1013 (3d Cir. 1972) (setting aside changes in Department of Transportation regulations because of inadequate notice).

66. See, e.g., United Steelworkers v. Marshall, 647 F.2d 1189 (D.C. Cir. 1989) (upholding OSHA's notice on lead standard), cert. denied, 453 U.S. 913. 
overturn an agency action for failure to comply with the APA's notice and comment requirements. Although the rules are more stringent today, they also are relatively clear and predictable, and agencies routinely comply with them. The courts have practically gone out of the business of imposing new procedural requirements on agencies. ${ }^{67}$ Thus, there are fewer occasions today for courts to reverse or remand agency actions on rulemakings.

It appears, then, that it is not the absolute stringency of judicial review that translates into reversals and remands, but rather an increasing marginal stringency. This occurs when courts are changing the law but agencies have not yet adapted their practices to the new regime. As the administrative state has matured, courts and the agencies have come to know one another better; the dictates of administrative law have become clearer; and agencies have found it less difficult to satisfy reviewing courts, at least in the overwhelming body of their caseload that does not he at the developing frontiers of the law.

The important point-and one on which our data and the AO data are in strong agreement-is that petitioners who challenge administrative decisions in court today confront a very low probability of success. In ordinary civil hitigation, there are strong reasons to beheve that, other things being equal, plaintiffs and defendants should each win about onehalf of the time when cases go to trial rather than settle. ${ }^{68}$ That rule, however, does not hold true in administrative law because the agency wins almost $90 \%$ of the time, while challengers win a hittle over $10 \%$ of the time. ${ }^{69}$ This raises an interesting question: Why do petitioners who face an almost certain chance of losing continue to file challenges to administrative actions in ever-imcreasing numbers?

One explanation, we beheve, is that the party challenging administrative action often has much to gain and very hittle to lose from judicial

67. See, eg., Vermont Yankee Nuclear Power Corp. v. NRDC, 435 U.S. 519,549 (1978) ("The court should ... not stray beyond the judicial province to explore the procedural format or to impose upon the agency its own notion of what procedures are "best' ....").

68. See, e.g., Priest \& Klein, The Selection of Disputes for Litigation, 13 J. Legal STUd. 1, 5 (1983) (mathematical model demonstrates that individual maximizing decisions of the parties will create a strong bias for a 50\% success rate for plaintiffs or appellants). But see Eisenberg, Testing the Selection Effect: A New Theoretical Framework with Empirical Tests, 19 J. LEGAL STUD. 337 (1990) (criticizing Priest-Klein methodology and rejecting their 50\% hypothesis as a description of all civil bitigation).

69. See supra Table 1. The Priest-Klein theory is not inconsistent with this observation, for it recognizes that "repeat players" (of which agencies are classic examples) will face different incentives to litigate than adversaries whose play is not as repetitive. Priest \& Klein, supra note 68, at 24 29; see also Galanter, Why the "Haves" Come Out Ahead: Speculations on the Limits of Legal Change, 9 LAW \& Soc'Y REv. 95, 124 (1974) (examining the "layers of advantages" that different classes of "haves" enjoy in hitigation with a particular focus on those advantages that accrue to "repeat players"). 
review. In such cases it may be rational for affected parties to challenge administrative action in court, even though they predict that their chances of prevailing are now substantially less than fifty-fifty. The balance of costs and benefits from challenging agency action in court obviously varies froin area to area. In deportation cases, for example, aliens who file a petition for review obtain an autonatic stay of deportation that will forestall action for inonths or even years. ${ }^{70}$ Petitioners therefore "win" in an important sense whether or not the court ultimately rejects disposition of their legal claims. In labor cases, most NLRB orders cannot be enforced against an employer or union until a circuit court issues an order to that effect. Yet, other agencies operate under different formal rules and practices concerning the time at which their orders become effective and the circumstances under which stays pending appeal can be obtained. The delay associated with remands can be an additional incentive to appeal. Remands almost always occasion significant delay, as our data, discussed in Part III(C), make plain. Measured conservatively, this delay ainounts to an average of sixtecn months at the agency level alone and exceeds four years in $10 \%$ of the cases.

Our data suggest still another explanation-that in general, parties and their lawyers perceive the benefits from successfully challenging agency action in court as large and the costs as small. Although the percentage of petitioners who win remand or reversal of agency action in court is low, the lawyers for those who win beheve that their chents have reaped large benefits in terms of actually changing the governinent's position. By and large, surprisingly, the lawyers for the governinent concur. As we describe in more detail subsequently, ${ }^{71}$ lawyers for petitioners and agencies agree that "major changes" in the agency's position result in approximately $40 \%$ of the cases that are remanded by courts. Yet the costs that petitioners must incur in order to obtain these benefits seem quite modest. Because the agency imitiates additional procedures to revise the administrative record in only $30 \%$ of the remands, the additional legal cost of seeking judicial review of agency action in most cases appears to be relatively limited. Many (though not all) petitioners' lawyers presumably nced to do little more than revise the briefs already prepared and filed at the agency level.

Before we undertook this study, we thought that judicial review of administrative actions was probably a waste of time in a great many cases. We now beheve that it may be rational for petitioners to challenge agency action in court even when they believe that the chances of success

70. 8 U.S.C. $\$ 1105 a(a)(3)$ (1988); see Schuck, The Transformation of Immigration Law, 84 COLUM. L. REV. 1, 76-77 \& n.432 (1984).

71. See infra Part III(D)(2), "Post-Remand Outcomes." 
are low. The costs of a challenge are relatively low, but the benefits can be very large if the petitioners can obtain a delay or if their challenge succeeds. Finally, however, the possibility that administrative lawyers are simply ignorant concerning the likelihood of success cannot be ruled out. ${ }^{72}$

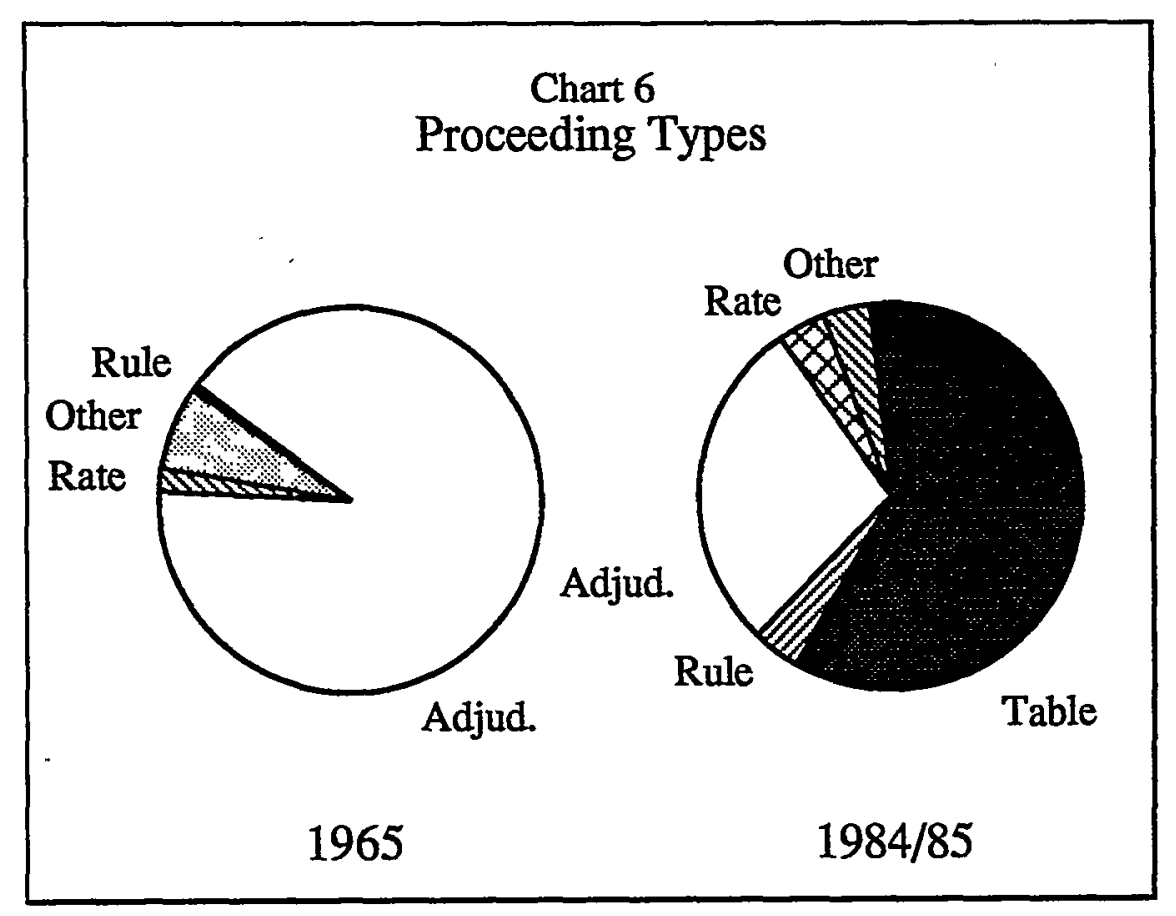

2. Types of Agency Proceedings. In the $\mathbf{1 9 6 5}$ period, more than 93\% of the agency proceedings reviewed by the federal courts of appeals (347 out of 372) were adjudications. In 1975, the proportion of adjudications fell to about $60 \%$, and by $1984-85$ that share dropped to about $34 \%$, or scarcely one-third of the agency proceedings. (See Chart 6. ) But the magnitude of this change during the latter two periods is overstated due to the large increase in the proportion of table decisions that occurred at the same time. Because we were unable to code these deci-

72. There is some empirical evidence that lawyers are poor predictors of the outcomes of their cases and tend to be over-confident concerning their chances of winning. See Loftus \& Wagenaar, Lawyers' Predictions of Success, 28 JURIMETRICs J. 437 (1988). 
sions as to type of proceeding, ${ }^{73}$ we excluded them from our analysis, but we strongly suspect that they were disproportionately adjudications. ${ }^{74}$

When we confined our analysis to those proceedings that we could code as adjudications, rulemakings, or ratemakings, we still found that the share of adjudications declined, although much less dramaticallyfrom about $98 \%$ in 1965 to about $87 \%$ in 1984-85. Limiting the sample in this way, the shares of rulemakings and ratemakings rose from $0.3 \%$ and $1.4 \%$, respectively, in 1965 to about $7 \%$ and about 5\% in 1975-a more than twenty-fold increase in the ease of rulemaking. Rulemakings declined to $6.5 \%$ in 1984-85, while ratemakings increased shightly to $6.5 \%$ in the same period. Even with this small decrease, rulemaking's share remained more than twenty times larger in 1984-85 than it had been twenty years earher, while ratemaking's share was more than four times larger.

The relatively low proportion of rulemakings, even in the most recent period, is somewhat surprising in light of the common perception that rulemaking has become a dominant form of agency decisionmaking during the twenty-year period. Our data cannot directly prove or disprove that perception, for they do not concern all agency proceedings, but only those that are reviewed by courts of appeals. Thus, if a significant number of rulemakings oceurred but were for some reason not appealed to those courts, then the conventional view could still be correct. It is possible, for example, that the more deferential standard of statutory review often applied to rulemakings might discourage appeals. On the other liand, one would expect that the more numerous parties, broader applicability, and policy significance associated witl rulemakings would increase, not decrease, the probability of appeals.

The use of aggregate data conceals some important clues about changes im agency use of rulemaking over time. Because the frequency of rulemaking is highly skewed across different agencies, changes in the representation of agencies in the caseload, which we discuss immediately below, miglit explain mucli of the change in the frequency with which different types of proceedings are used. The three largest contributors to the appellate courts' current administrative law dockets-the National Labor Relations Board (NLRB), Merit Systems Protection Board (MSPB), and the Immigration and Naturalization Service (INS)-are agencies that still engage almost exclusively im adjudication. Indeed, our

73. During each period, there were also a small number of non-table decisions that were coded as "other."

74. The National Labor Relations Board, Immigration and Naturalization Service, and Merit Systems Protection Board alone accounted for two-thirds of the table decisions in the 1984-85 dataset. 
large dataset did not contain a single rulemaking proceeding by any of these three agencies. There also were no rulemakings in the much smaller number of Department of Labor (DOL) and patent and trademark cases in the dataset. Rulemaking is inore prominent, however, in the other four agency groups-those that we called "health and environment," "other regulatory," "other departments," and "other." In those agencies, rulemaking's share of all cases rose from less than $1 \%$ in 1965 to $12.3 \%$ in 1975 , only to fall to $9.4 \%$ in $1984-85$.

This is an intriguing and important finding. It shows that the apparent decline in rulemaking between 1975 and 1984-85 does not reflect simply the rejection of rulemaking by the three large-volume agencies that dominate the administrative law docket, for the decline also has occurred in agencies that do use rulemaking to some extent. An important reason for this trend may be that between 1975 and 1985 reviewing courts increasingly constrained agency rulemaking by imposing adjudicatory-type evidentiary and procedural burdens on agencies engaged in rulemaking. ${ }^{75}$ Another reason may be that the Reagan Administration resisted rulemaking for political or policy reasons. ${ }^{76}$ Whatever the cause of the reduction in the use of rulemaking, our data indicate that this phenomenon appears in a wide variety of agencies.

3. Review of Particular Agencies. The agency composition of the administrative law caseload has changed significantly during the twentyyear period we studied. (See Chart 7.) In 1965, two agencies-the NLRB and the Patent and Trademark Office-dominated the picture, and together accounted for over $61 \%$ of the caseload, spht roughly equally between them. In the 1984-85 period, however, the NLRB's share dropped to just under $16 \%$ and the Patent and Tradeinark Office's share declined to $6 \% .{ }^{77}$ On the other hand, the MSPB, which did not

75. See, e.g., Schuck, When the Exception Becomes the Rule: Regulatory Equity and the Formulation of Energy Policy Through An Exceptions Process, 1984 DUKe L.J. 163, $194-96$ (discussing how the changes made in the process and review of rulemaking have made use of the rulemaking process less advantageous). For an extended exploration of this theme in the context of National Highway Traffic Safety Administration rulemaking, see Mashaw \& Harfst, supra note 5.

76. Alan B. Morrison, a prominent administrative law hitigator in the federal courts, asserts this explanation. See Letter froin Alan B. Morrison to Peter H. Schuck (July 16, 1990) (available from authors). Our data indicate that the number of rulemakings reviewed by the circuit courts during the six-month periods covered by the study increased from one in 1965, to 14 in 1975, to 24 in 1984, and then declined to 18 in 1985 . The increase between 1975 and 1984, however, is not necessarily inconsistent with resistance to rulemaking by the Reagan Administration because the possible occasions for rulemaking (statutorily mandated and otherwise) were greater during the more recent period.

77. The Patent and Trademark Office (PAT) (in contrast to common usage, we refer to the Patent and Trademark Office as "PAT") experienced a sharp decline between 1965 and 1985 not only in its share of the administrative law caseload in the circuit courts, but also in the absolute 


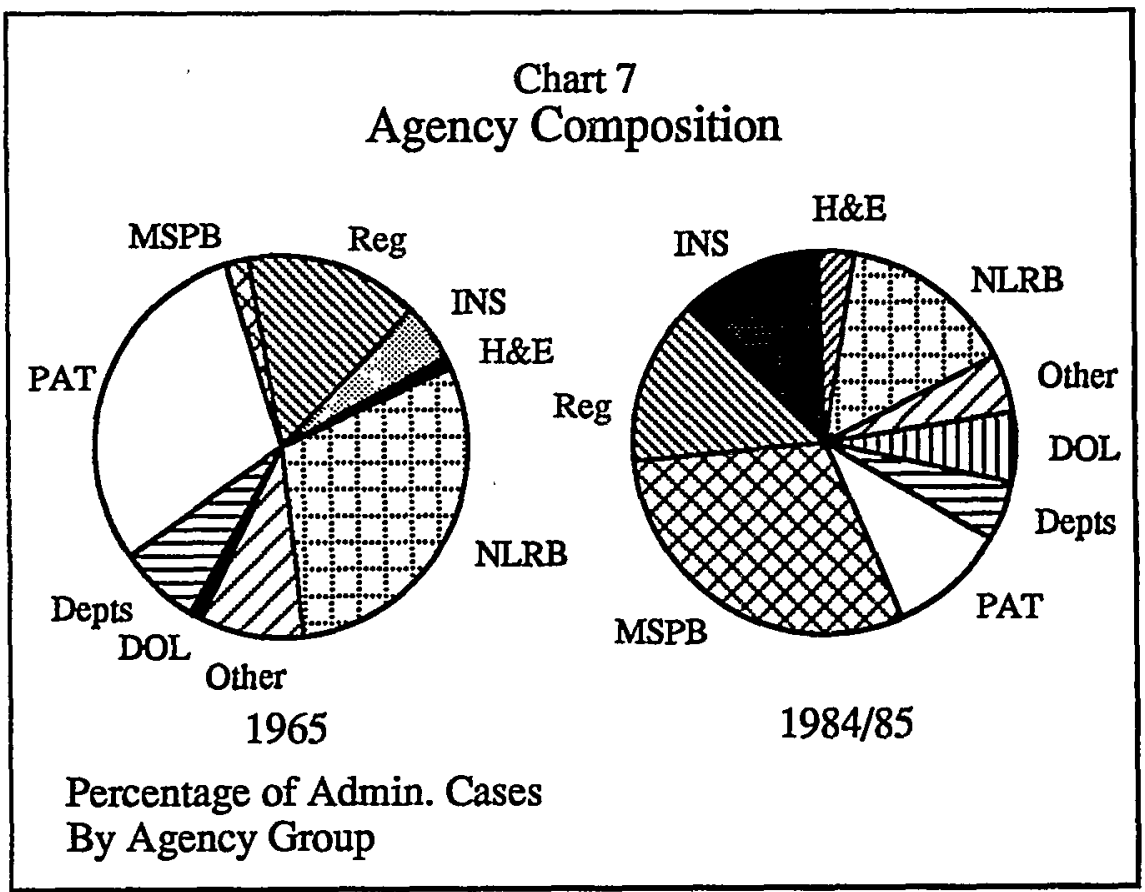

even exist until 1978,78 now accounts for $27.5 \%$ of the caseload, while immigration cases, which comprised only $5.4 \%$ of the caseload in 1965 , now account for $13.7 \%$ and comprise the third largest group of cases (after the NLRB and MSPB cases).

This more recent domination of the caseload by labor, personnel, and immigration cases also helps to explain why, as noted above, adjudication's share of the caseload has not changed significantly simce 1965, despite the greater number of rulemaking proceedings in subsequent periods: The NLRB and the MSPB employ adjudication almost exclusively. Although the INS sometimes issues rules, its proceedings also are overwhelmingly adjudications concerned with the exclusion, deportation, and the adjustment of status of individuals.

One unexpected finding concerns a change that has not occurred. Because "social regulation" seeking to protect health, safety, and environmental $(\mathrm{H} \& \mathrm{E})$ interests has generated intense controversy and bitterly-contested hitigation since the early 1970s, we had supposed that

number of its cases being reviewed there-from 111 in the six-month period in 1965, to 56 in the corresponding period in 1985. See supra Chart 7 and accoinpanying text. In contrast, the absolute number of NLRB cases during the two periods remained the same (118).

78. Until the 1978 Civil Service Reform Act created the MSPB, appeals from Civil Service Commission personnel actions went to the district courts. Accordingly, they were not included in our dataset. 
almost fifteen years later the circuit courts would be directly reviewing a large number of these disputes. In the 1984-85 period, however, such cases comprised ouly $3.6 \%$ of the caseload-larger than the $0.3 \%$ share in 1965, to be sure, but still insignificant in terms of the caseload as a whole.

4. Circuit Court Caseloads. Our data concerning the administrative law caseload and its distribution among the circuit courts over the course of the two decades reveal some interesting and surprising patterns. First, although the administrative law caseload of the appellate court system as a whole grew substantially between 1965 and 1985, the trajectory of that growth was by no ineans smooth. Here, we found a conflict betwecn our data and that compiled by the Administrative Office of the Umited States Courts (AO). Based on our six-inonth samples, the caseload actually declined by more than $25 \%$ between 1965 and 1975. In contrast, the AO data show an imcrease of $39 \%$ during this period.

Even allowing for the spasm of anti-regulation and regulatory reform sentiment during the Ford Administration, ${ }^{79}$ the existence of a decline (not to mention a decline of this magnitude) shown by our data was quite unexpected. The 1975 period, after all, followed (and in some cases coincided with) the creation of a number of new regulatory agencies and an expansion in the regulatory programs and authorities of existing agencies. ${ }^{80}$ We cannot fully account for this caseload decline between 1965 and 1975.81

A second interesting point that emerges from comparing data for 1965,1975 , and 1985 is that the D.C. Circuit's share of the total administrative law caseload reinamed essentially unchanged during the twenty-

79. See, eg., SUBCOMMTTteE ON OVERSIGHT AND INVESTIGATION OF THE HOUSE COMMITtee on INTERstate and Foreign COMmerce, Federal Regulation and Regulation ReFORM, H.R. Doc. No. 95-134, 95th Cong., 1st Sess. 3 (1976) (recommending "fundamental adjustments in the political environment of regulation and new structures for increasing the accountability of agency actions to broad public interests").

80. See Lilley \& Miller, The New "Social Regulation," 47 PUB. INTEREST 49, $51-52$ (1977) (between 1970 and 1975 seven major regulatory agencies were created, 30 important federal regulatory acts were passed, and 309 new regulations and 7305 rule amendments were publislied in the Federal Register).

81. Concerned that this decline might have been caused by careless data collection for the 1965 and 1975 periods, we constructed a WESTLAW searcl designed to identify cases fitting our criteria for inclusion. The search technique is explained in Appendix C. We then compared the cases so generated against those already in our database. The fit was pretty close, but not perfect; in any event, the number of discrepancies was not nearly large enough to have caused the caseload decline. After the searcl, we again read the discrepant cases and added to our database those which the earlier data collectors had missed.

In the end, about $90 \%$ of the $1965-75$ caseload decline was caused by a decrease in the number of patent and trademark cases coming into the appellate courts during that period. 
year period; it was $11.6 \%$ in 1965 and $12.4 \%$ in 1984-85. These data evidently do inask some short-term fluctuations in the D.C. Circuit's caseload share; its share almost doubled in 1975, rising to $22.7 \% .82$ (See Chart 8.) Even so, however, this long-term stability is striking and puzzling, particularly during a period in which at least one important regulatory statute sought to centralize appellate jurisdiction in that circuit, ${ }^{83}$ and in which administrative lawyers perceived a steady growth in its prominence and power.

Third, the busiest circuit by far in the most recent period was the Federal Circuit, whose caseload share was $36.4 \%$, three times that of the D.C. Circuit, and two and a half times that of its closest competitor, the Ninth Circuit. (See Chart 9.) The Federal Circuit was established in 1981 and absorbed the jurisdictions of several existing tribunals. Two of these-the Court of Claims and the Court of Custorns and Patent Appeals ${ }^{84}$ - together had accounted for $44.3 \%$ of the total cases in 1965, but only $18.4 \%$ in 1975 . In addition, the Federal Circuit hears appeals from the MSPB, which, as noted above, now accounts for the largest number of cases of any agency in our dataset.

5. The Composition of Reviewing Courts. The composition of reviewing courts in administrative law cases has changed over time. In 1965 , inorc than $38 \%$ of the agency cases were reviewed en banc; the Court of Claims and the Court of Customs and Patent Appeals, which together constituted nearly one-half of the administrative law caseload, almost always sat en banc. By 1975, however, only about $6 \%$ of cases were heard en banc; as in 1965, all but one of these hearings were in one of the two specialized courts. By 1985, en banc cases were only $1.7 \%$ of the caseload, and one-third of those were in the Federal Circuit. In 1965, $56.2 \%$ of the cases were decided by three-judge panels, $38.4 \%$ were decided en banc, and the rest (5.4\%) were decided by panels of four or inore judges, but not en banc.85

It is not possible to compare the 1965 data to those for 1975 and 1984-85; as to those two periods, we inust exclude table decisions because West Publishing does not indicate the court's composition in such cases (although presumably they are almost all three-judge panels). In 1975, three-judge panels heard $86.9 \%$ of non-table deeisions; $6.1 \%$ of the cases

82. The data also reveal fluctuations of this kind in certain other circuits. For example, the First Circuit's caseload share changes from $3.8 \%$ to $5.8 \%$ to $1.4 \%$ over the three periods.

83. See 42 U.S.C. $\$ 7607$ (b)(1) (1988).

84. The Federal Circuit also hears appeals from the MSPB, certain international trade decisions, and the Tax Court.

85. The share of cases decided by panels of four or more judges but less than en banc has always been small; it was under 6\% in 1965 and under $2 \%$ in 1985. 


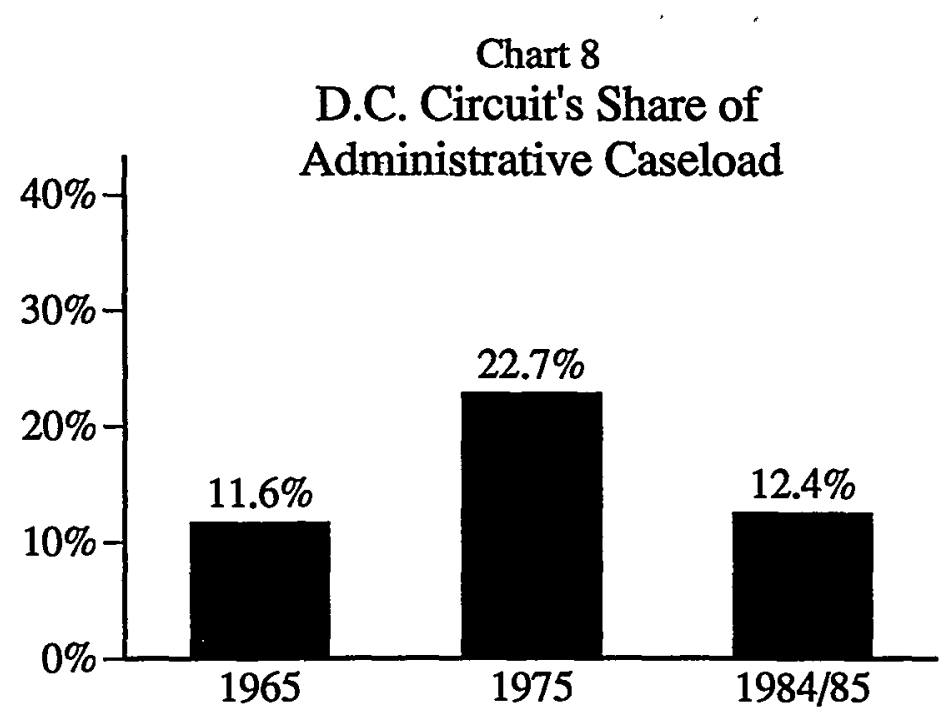

Percentage of Administrative

Cases Decided by D.C. Circuit

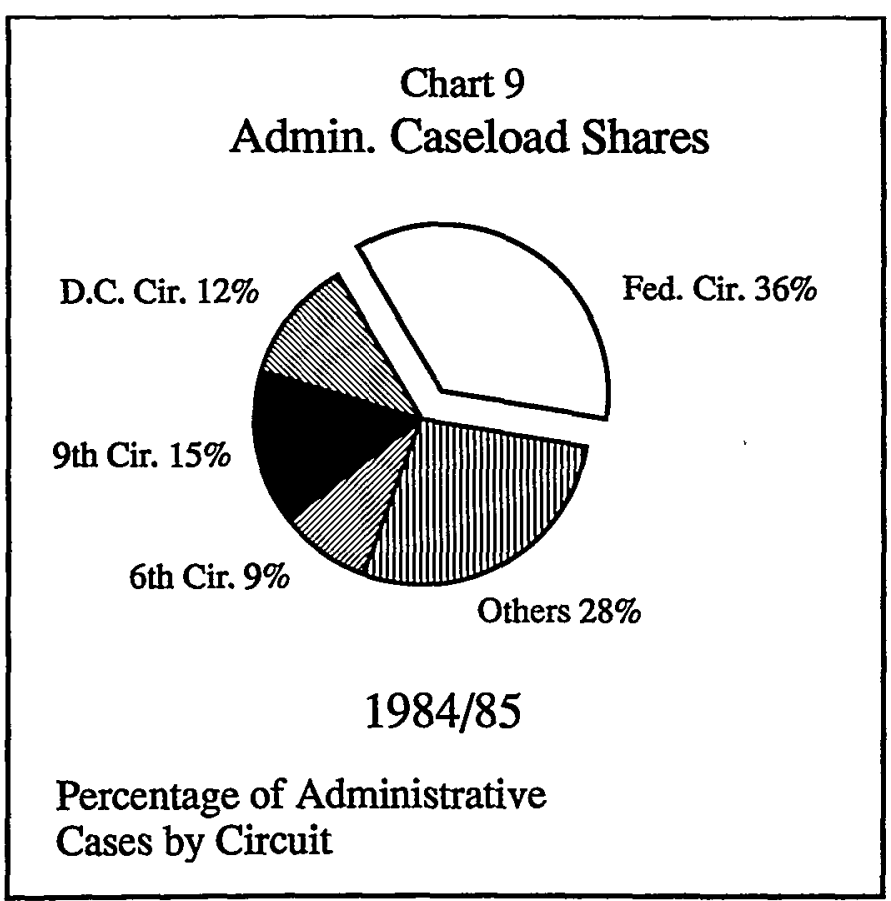


were decided en banc, and $7.1 \%$ were decided by a panel of more than three judges, but less than en banc. In 1984-85, three-judge panels accounted for almost $97 \%$ of the non-table decisions; the number of en banc and larger panel cases were both negligible.

The rapid growth in the use of table decisions already has been noted, and the decline in the use of larger panels probably can be explained by efficiency considerations. But the mcreasing rarity of en banc deeisions in administrative law cases (only 12 out of the 688 non-table decisions-and presumably none of the 988 table decisions-in the 198485 period sainple), especially outside the Federal Circuit, is striking. ${ }^{86}$

\section{Remands and the Chevron Effect}

1. The Pattern of Remands: Remands During 1984-85. We were interested in two different aspects of remands in general, ${ }^{87}$ each of which generated an initial set of hypotheses. One set only concerned remands that occurred during the most recent period (1984-85), while the other aspect was dynamic and concerned with changes in the pattern of remands since 1965.

: We began by supposing that the likelihood of each type of appellate outcome (that is, affirmancc, reversal, remands of different kinds, and "other"88) wonld not vary significantly among different agencies and among different circuits. Our thinking can be stated simply: We did not know of any specific reasons to expect systematic variations-or of any widely-accepted, well-specified theory of agency or appellate court behavior that would predict such variations. To be sure, fragmentary observations might be used to support certain predictions. For example, one might expect the NLRB, which engages only in adjudication, to suffer more reversals and remands than would health, safety, and environmental agencies that do more rulemaking, which is subjected (in principle) to a more deferential standard of review. One also miglit predict that the D.C. Circuit would reverse and remand more than the other

86. En banc decisions are apparently even rarer in non-administrative law cases and are declining there as well, at least as a percentage of the total caseload. See Solimine, Ideology and En Banc Review, 67 N.C.L. REV. 29, 46 (1988) (en banc decisions as percentage of entire caseload declined from $0.61 \%$ in 1980 to $0.48 \%$ in 1987 ).

87. The particular effects of Chevron on remands are considered in the next section, infra Part III(C)(2), "The Effects of Chevron."

88. Examples of dispositions that we coded as "other" include decisions dismissing for lack of jurisdiction or for lack of a final order subject to review, decisions on an application for attorneys' fees, decisions on a motion to add another agency as a party, decisions granting reliearing, and the like. 
circuits. ${ }^{89}$ But for each of these theories, one also could propose a plausible counter-theory. None of them seems very satisfying. ${ }^{90}$

The data strongly refute our initial null hypothesis. Among different agencies (or at least among our agency groupings), the data reveal considerable variation in judicial review outcomes. Several general observations bear mentioning. First, a majority of the eases in all agency groupings were affirmed in toto. If we define such a disposition as an unambiguous agency "success," the precise success rate among some of the agency groupings varied a great deal. During 1984-85, the most successful agency was the MSPB (90\%), whereas the least successful were the DOL and "other regulatory agency" groupings (about 60\% each). (See Chart 10.)

Notice, however, that Chart 10 is characterized by a bimodal distribution: There are two distinct groupings of agencies with different success rates im court. One grouping clusters around an $80 \%$ affirmance rate (INS, MSPB, PAT, Other Departments), whereas a second grouping clusters around a much lower affirmance rate of $60 \%$ (Health \& Environinent, Other Regulatory, DOL, and Other). Our data strongly suggest that the disparity im success rates between the two groupings is related to the different types of proceedings through which they make their decisions. The group with the higher, $80 \%$ affirmance rate used adjudication in over $99 \%$ of their cases (332 of 335), whereas the group with the lower, $60 \%$ affirmance rate used adjudication im only $86 \%$ of their cases (236 of 275). The disparity could be explamed if it were the case that the agencies experiencing lower success rates were agencies that more frequently used rulemaking proceedings.

Agam, our data provide some support for this interpretation. Among the reported opimions in the 1984-85 dataset (excluding table cases, which could not be coded as to proceeding type), the courts affirmed $60.4 \%$ of the adjudications in toto, but only $40.4 \%$ of the rulemakings were affirmed in toto. Moreover, this pattern of lower

89. One theory would stress the importance of judicial ideology. Since the D.C. Circuit was widely regarded as perhaps the most "liberal" or "activist" circuit-at least during the 1965 and 1975 periods covered by the study-one might expect that court to use judicial review as a way to reverse the process of agency "capture" that was prominent during those periods and that occasionally surfaced in opinions of that court. Another theory-call it the "familiarity breeds conteinpt" idea-would stress that the volume of agency cases coming before the D.C. Circuit was so great that the court would be less awed by claims of agency expertise than other courts without inuch experience with agencies.

90. To recur to the examples mentioned previously, as an "old-line" agency with a fully-elaborated administrative law, the NLRB might receive greater judicial deference than relatively new agencies, whose credentials were not as well-established. As for the D.C. Circuit, its hiberal orientation might cause it to sympathize with activist, pro-regulation agencies, while its administrative law experience inight encourage respect for technical claims rather than skepticism. 


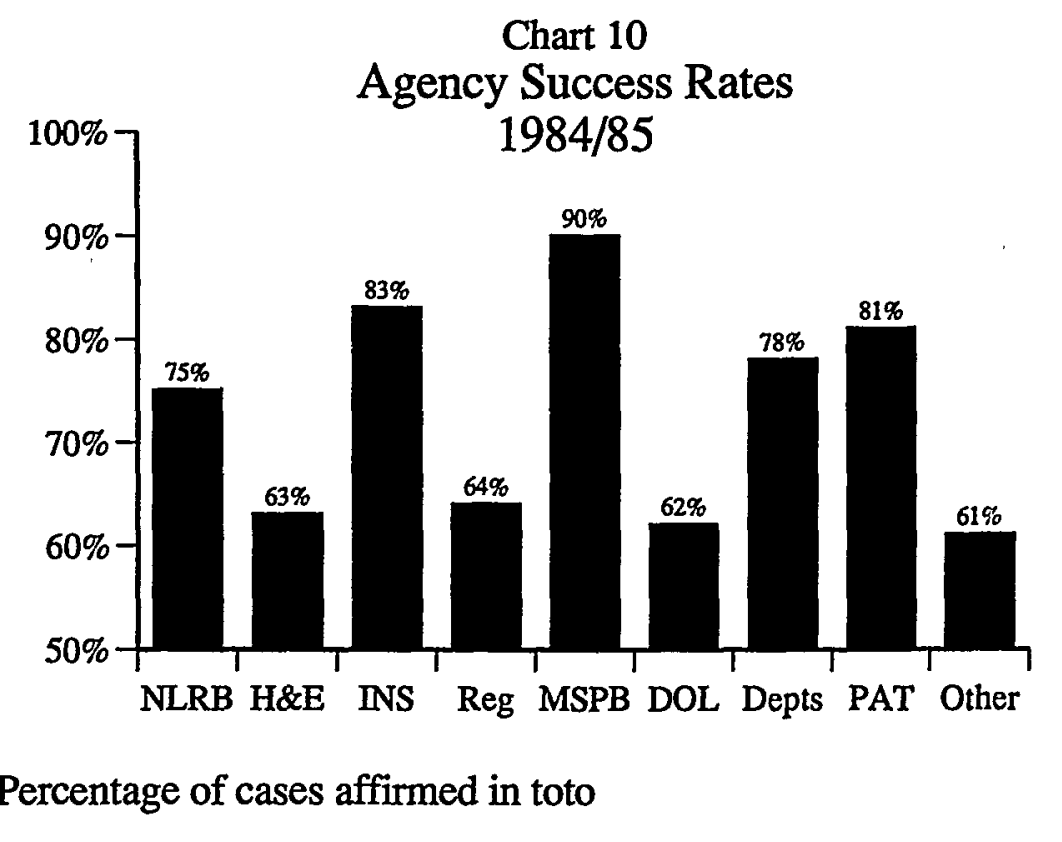

agency success rate for rulemaking, as opposed to adjudication, was found for all time periods. When the 1965,1975 , and 1984-85 data for reported opinions from all agencies are combined, a systematic difference in success rates emerges: Adjudications have enjoyed a long-term success rate of $57.8 \%$ (625 of 1082 cases), compared to only $43.9 \%$ ( 25 of 57) for rulemakings-im other words, the success rate for rulemaking has been only three-quarters that for adjudications. And if we include table cases-which we beheve are disproportionately adjudications, and which we know are about $90 \%$ affirmances in the 1984-85 period-the success rates for adjudications would be even higher.

There are far too few rulemakings in our sample (only $2.5 \% \mathrm{~m}$ 1984-85) for the success rate disparities between adjudications and rulemakings to account fully for the differences in success rates among agency groupimg observed in Chart 10. Rather, it is likely that the nature of the subject matter, which tends to correlate roughly with rulemaking as opposed to adjudication, may be the key factor im explaining the differences in agency success rates. Thus, our data suggest (though they certainly do not prove) that agencies may be less likely to be affirmed in cases that imvolve broad policy questions and multiple parties-charac- 
teristics generally associated with rulemakings ${ }^{91}$-as opposed to cases that involve only individual hitigants, which tend to be confined to narrower issues.

There are other possible explanations for these differences in agency success rates, explanations on which our data shed hittle light. It may be, for example, that the Federal Circuit, which reviews MSPB cases, defers more to that agency-perhaps because the personnel matters that it must decide turn more often on issues of credibility, on which the agency usually enjoys a comparative advantage over the reviewing court. The variation in success rates among agencies, however, also may reflect other factors such as different standards of review, ${ }^{92}$ different incentives to litigate, different kinds of hitigation adversaries, and so on.

2. The Effects of Chevron. The Supreme Court's Chevron decision, as clarified and reaffirmed in its Chemical Manufacturers decision only eight inonths later, was widely interpreted as a landmark ruling in administrative law. ${ }^{93}$ Most commentators agreed that in these rulings the Court strongly signaled its intention that reviewing courts defer more to agency interpretations of their statutory authority. ${ }^{94}$

Chevron was not without precursors. At least since 1944, there had becn a line of Supreme Court authority that reviewing courts should defer to agencies' constructions of their governing statutes so long as those constructions were "reasonable."95 There also was a contrary line of cases, however, in which courts themselves construed statutes and gave hittle or no deference to administrative interpretations. ${ }^{96}$ The inconsis-

91. Cf. Shapiro, Administrative Discretion: The Next Stage, 92 YALE L.J. 1487, 1500-11 (1983) (typology of various types of discretionary decisions by agencies, including "high-volume, low-level decisions" and broad policy decisions under "thematic statutes").

92. We did code the cases in our datasets for the standard of review. Because the courts often failed to state explicitly what particular standard they were applying, however, we have less confidence in the accuracy of these codings and we liave not reported those results liere.

93. Chemical Mfrs. Ass'n v. NRDC, 470 U.S. 116 (1985). For an example interpreting Chemical Manufacturers as such a decision, see, e.g., Starr, Judicial Review in the Post-Chevron Era, 3 YALE J, ON REG. 283, 284 (1980) (referring to Chevron as "watershed decision").

94. The test involves two steps. First, the reviewing court determines whether there exists specific congressional intent on the issue in question. If the court discerns such intent, either express or implied, agency interpretations to the contrary are to be overruled. Second, if there is no such specific congressional intent, the court assesses whether the agency's interpretation is based on a permissible construction of the statute. "Such legislative regulations are given controlling weight unless they are arbitrary, capricious, or manifestly contrary to the statute. . . . [A] court inay not substitute its own construction of a statutory provision for a reasonable interpretation inadc by the administrator of an agency." The test is spelled out completely in Chevron, U.S.A., Inc. v. NRDC, 467 U.S. 837, 842-44 (1984); see also Starr, supra note 93.

95. See Udall v. Tallman, 380 U.S. 1, 4 (1964); NLRB v. Hearst Publications, Inc., 322 U.S. 111 (1944).

96. See United States v. Swank, 451 U.S. 571 (1981); Morton v. Ruiz, 415 U.S. 199 (1974). 
tency between these two lines of cases did not escape the notice of the commentators. 97

The confused state of the law prior to Chevron can be summed up by referring to $S E C$ v. Sloan, 98 a 1978 decision in which the Supreme Court overturned the Security and Exchange Commission's (SEC) interpretation of its statutory authority to suspend trading under section 12(k) of the 1934 Securities Exchange Act. ${ }^{99}$ The Court reviewed numerous factors that supposedly governed the extent of deference that courts owe to administrative constructions of statutes, such as whether the administrative interpretation is "of long standing" 100 and "the thorougliness evident in [the agency's] consideration, the validity of its reasoning, [and] its consistency with earher and later pronounceinents."101 The Court had to concede that the SEC's interpretation satisfied most, if not all, of these criteria. The Court nonetheless overturned the SEC's reading of the statutory language, concluding that the agency's reading was "not the inost natural or logical one."102

In Chevron, the Supreine Court swept aside all of these criteria for determining the extent of deference and set forth a dramatic reformulation of the grounds for deferring to agency constructions of statutes. An ambiguous statute, the Court reasoned, should be considered an implicit legislative "delegation"103 to the administrative agency of the discretion to deeide which of several permissible interpretations of the statute to adopt. After Chevron, it no longer inakes sense to speak-as the Court itself liad spoken only a few years earlier in $S E C v$. Sloan-of a statute administered by an agency as having a single "inost natural or logical" meaning. If that were the issue, courts presumably would be at least as adept as agencies at discerning Congress' ineaning. But in Chevron, the Supreme Court no longer conceptualized statutory construction as the inethod of finding a single, correct ineaning on every point. Rather, an ambiguous statute is now conceived as creating a policy space within

97. See, e.g., Pittston Stevedoring Corp. v. Dellaventura, 544 F.2d 35 (2d Cir. 1976), aff'd sub nom. Northeast Marine Terminal Co. v. Caputo, 432 U.S. 249 (1977). In Pittston, Judge Friendly wrote that "there are two lines of Supreme Court decisions on this subject which are analytically in conflict, with the result that a court of appeals mnst choose the one it deems more appropriate for the case at hand." Id. at 49. See also $5 \mathrm{~K}$. DAVIS, ADMINISTRATive LAw TrEATISE $\$ 29.07$ (1984); Gellhorn \& Robinson, Perspectives on Administrative Law, 75 CoLUM. L. REv. 771, 780-81 (1975).

98. 436 U.S. 103 (1978).

99. 15 U.S.C. \& 78(k) (1988).

100. Sloan, 436 U.S. at 118.

101. Id. (quoting Skidmore v. Swift \& Co., 323 U.S. 134, 140 (1944)).

102. Id. at 112 .

103. Chevron, U.S.A., Inc. v. NRDC, 467 U.S. 837, 844 (1984). 
which the agency is free to move, provided that its actions are reasonable and do not exceed the ambit of congressionally-delegated authority. 104

According to Chevron, the issue of whether a court should defer to an agency construction of a statute reduces to two questions:

When a court reviews an agency's construction of the statute which it administers, it is confronted with two questions. First, always, is the question whether Congress has directly spoken to the precise question at issue. If the intent of Congress is clear, that is the end of the inatter; for the court, as well as the agency, inust give effect to the unambiguously expressed intent of Congress. If, however, the court determines Congress has not directly addressed the precise question at issue, the court does not simply impose its own construction on the statute, as would be necessary in the absence of an administrative interpretation. Rather, if the statute is silent or ambiguous with respect to the specific issue, the question for the court is whether the agency's answer is based on a permissible construction of the statute. ${ }^{105}$

As the italicized passages suggest, however, Chevron's two questions are themselves ambiguous. How clearly must Congress have spoken before its "intent" is binding on an agency? And how is a reviewing court to determine whether the agency's construction of the statute is "permissible" except by construing the statute for itself in the traditional way?

In the months immediately following Chevron, several courts of appeals attempted to cut Chevron down to size by reading the opinion as having left substantial leeway for courts to find "inıphed intent" by Congress based on statutory language, overall statutory purpose or the legislative history. ${ }^{106}$ In Chemical Manufacturers ${ }^{107}$ (decided only eight months after Chevron), and several other decisions thereafter, ${ }^{108}$ the Court reaffirmed its Chevron analysis. The Chemical Manufacturers decision was particularly significant; there, the court of appeals had relied on explicit statutory language and legislative history in overturning the agency's construction of the statute. The Supreme Court reversed, citing Chevron and holding that the issue was for the agency because "the

104. For an excellent summary of Chevron and the lines of authority that preceded it, see Starr, supra note 93.

105. Chevron, 467 U.S. at $842-43$ (emphasis added) (footnotes omitted).

106. See, eg., Rettig v. Pension Benefit Guar. Corp., 744 F.2d 133, 144-54 (D.C. Cir. 1984) (although the court found no explicit congressional intent on question of interpretation of Employee Retirement Income Security Act (ERISA), it implied intent froin the "preponderance of evidence" gleaned from the legislative history).

107. 470 U.S. 116 (1985).

108. See, e.g., Board of Governors v. Dimension Fin. Corp., 474 U.S. 361 (1986) (affirming Chevron but finding Federal Reserve Board's regulation defining "banks" as outside statutory authority); United States v. City of Fulton, 475 U.S. 657 (1986) (Secretary of Energy not prohibited by Flood Control Act from establishing imterim lydroelectric power rates); Umited States v. Riverside Bayview Homes, Inc., 474 U.S. 121 (1985) (holding Corps of Engineers' extension of regulatory authority as reasonable under statutory authority). 
wording and legislative history of the statute ... [do] not evince an unambiguous congressional intention to forbid" the course chosen by the agency. ${ }^{109}$

If the Court ineant what it said in Chevron and its progeny, and if reviewing courts took its words seriously, one would expect the distribution of outcoines in agency cases to change to reflect the effects of Chevron. In particular, one would expect the courts to affirm more frequently and to remand less frequently. As Solicitor General Kenneth Starr (then a judge of the Umited States Court of Appeals for the D.C. Circuit) observed, in Chevron "the Supreme Court imvalidated what had been a rather common method of overturning agency interpretations" of statutes. ${ }^{110}$ A central goal of our study was to determine whetler legal treinors of this inagnitude, significant but subtle clianges in legal doctrines, actually affect the subsequent beliavior of the lower courts in reviewing administrative decisions. For a number of reasons, we did not share the expectation that outcoines would cliange after Chevron. By explaining our reasons, 'we lope to underscore the significance of what we did find.

To begin with, we have been educated and have coine to professional maturity in the sliadow of the Legal Realist tradition. This tradition, which we sliare with most contemporary lawyers, einphasizes that legal rules often are indeterminate and malleable, and that these characteristics of law enable courts to exercise discretion in shaping their decisions. Courts, in the Realist view, choose according to a variety of considerations that are wholly extrinsic to the rules themselves, including the judges' policy preferences, their conceptions of institutional roles, their theories of justice, craft norıns, and the like. ${ }^{111}$

In general, we share this view and we believed that it was especially accurate as an account of low most courts review agency cases. Courts, after all, possess both the motivation and the institutional and doctrinal freedom to ride herd on agencies. Powerful structural and constitutional concerns drive courts in that direction: Agencies are armed with the coercive, redistributive power of the nation; they act under open-ended delegations of authority from Congress; and their appointed officials combine governmental functions that our constitutional scheme has sought to diffuse. If courts are suspicious of agency power, their mistrust only mirrors that of members of Congress and the general public.

109. Chemical Mfrs, 470 U.S. at 129.

110. Starr, supra note 93, at 295.

111. See, e.g., J. FRANK, LAW AND THE MODERN MIND 100-17 (1949) (Judges are influenced by a multitude of factors, many of them unconscious. Because "legal rules" play ouly a small part in the judicial decisionmaking process, law can never be entirely predictable.). 
The circumstances under which circuit courts operate also strongly tempt them to intervene to review agency decisions. The standards and scope of judicial review often are broad and unconstraining. The records in administrative cases often are so extensive that reviewing courts can extract from thein plausible grounds for either an affirmance or a remand. Congress often legislates against a background practice of close judicial review, and reaffirms and relies upon that practice. In addition, the probability that the Supreme Court will review, much less reverse, any particular decision by a circuit court is very low.

Thus, appellate courts' close scrutiny of agency decisions has been legitimated by basic constitutional values, fueled by deep institutional suspicions, and fortified by legal and strategic considerations. This practice is now deeply embedded in our system. Indeed, it is so firmly establislied that even Congress would find it exceedingly difficult to cliange the essential character of judicial review in agency cases. ${ }^{112}$ In terms of the present inquiry, this observation raises two questions: How effective in general is the Supreme Court likely to be in actually inducing the circuit courts to be inore deferential to agency decisions? And given the fact that the Court plainly attempted to do just that in Chevron, lias it succeeded in this task?

The evidence concerning the effectiveness of Supreme Court decisions in altering the behavior of the lower courts is mixed: Results seem to turn upon inany factors, including how clearly the Court defined its normative requirement, how workable tliat requirement seems to be in practice, how costly it is for litigants to identify deviations from that norm, and whether the norm can be implemented ouly with the cooperation of extra-judicial actors, such as a bureaucracy. ${ }^{113}$ These factors suggest that the Court's success in sliaping lower court belhavior will vary according to the area of law and the policy domain in question.

However the question of the effectiveness of Supreme Court supervision may be answered generally, we are not entirely at sea when we seek to answer it in the particular context relevant to this study-administrative law. Two case studies of recent efforts by the Court to require reviewing courts to accord greater deference to agency decisions provide strong grounds for doubting the effectiveness of those efforts. ${ }^{114}$

112. E.g., Lindahl v. Office of Personnel Management, 470 U.S. 768 (1985). Congress' hostility to limits on judicial review is suggested by the Veterans' Judicial Review Act-Veterans' Benefits Improvement Act of 1988, Pub. L. No. 100-687, 102 Stat. 4120 (1988) (codified at 38 U.S.C. § 4092 (1988)).

113. See P. Schuck, supra note 1 , at chs. 1,6 \& 7.

114. See T. Alemnikoff \& D. Martin, Immigration: Process And Policy 516-27 (1985) (faced with what they deein to be compelling humanitarian concerns, lower courts have resisted Supreme Court's desire in INS v. Wang, 450 U.S. 139 (1981), to be less intrusive in suspension of 
These examples (and others) of how reviewing courts can thwart the Supreme Court's demands for greater deference to agencies made us skeptical that Chevron and Chemical Manufacturers would enjoy much success. Indeed, certain aspects of these decisions reinforced our doubts. To begin with, the Court proposed to treat deference as a categorical rule, equally apphicable in the great variety of situations in which it may arise. Further, it secmed likely to frustrate, rather than advance, Congress' purposes concerning court-agency relationships, which sometimes favor less deference rather than more. It would also produce some unnecessary procedural delays and coinplexities in a system that is already overburdened. Fimally, it called for a degree of judicial forbearance in the face of perceived agency error that many courts would find difficult to sustain. ${ }^{115}$

An additional reason for doubting the efficacy of the Court's instruction in Chevron grew out of the opinion itself. Despite the Court's determination to exact from reviewing courts greater deference to agency policymaking, the Court's language failed to instruct the circuits with the unmistakable clarity and inoral autliority that seem minimally necessary (although not always sufficient) for the Court to succeed in altering the shape of court-agency relationships. Instead, the language of the opinion contained some important ambiguities and raised new and difficult questions. ${ }^{116}$ These uncertainties enabled the circuit courts to adopt the strategy that they had pursued successfully in the wake of Vermont Yankee Nuclear Power Corp. v. NRDC ${ }^{117}$ and INS v. Wang. ${ }^{118}$ They could affirm Chevron's authoritativeness generally while retaining plenty of maneuvering room in specific cases, should they conclude that the agency's

deportation cases); Scalia, Vermont Yankee: The APA, The D.C. Circuit, and the Supreme Court, 1978 SUP. CT. REV. 345 (D.C. Circuit remarkably ineffective in implementing principles of interpretation in wake of Vermont Yankee Nuclear Power Corp. v. NRDC, 435 U.S. 519, 549 (1978)). In both Vermont Yankee and Wang, the Supreme Court spoke to the reviewing courts with unusual vehemence and clarity.

115. See, e.g., Breyer, Judicial Review of Questions of Law and Policy, 38 ADMIN. L. REv. 363, 373-82 (1986) (discussing problems caused by ambiguous language in Chevron); Sunstein, Deregulation and the Courts, 5 J. POL'Y ANALYSIS \& MGMT. 517, 528-30 (1986) (outlining problems in following Chevron's "clear statement" approach).

116. Several commentators have explored these questions raised by the Court's language. See, e.g., Anthony, Which Agency Interpretations Should Bind Citizens and the Courts?, 7 YALE J. ON REG. 1 (1990) (Congressional intent in delegating authority to agencies should determine whether reviewing court inust accept agency interpretation); Breyer, supra note 115 (arguing that the strict verbal interpretation of Chevron, embraced by some lower courts, will give way to a more complex approach that better reflects judicial rcality); Sunstein, supra note 115 (arguing that the "clear statement" approach is flawed because it is unlikely to serve Congress' own goals and expectations; it unnecessarily restricts judicial discretion; and it fails to provide a constitutional check on agency power).

117. 435 U.S. 519 (1978).

118. 450 U.S. 139 (1981). 
position was unjustified. ${ }^{19}$ Thus, although we never imagined that the circuit courts would openly defy Chevron, we did expect that they would find it easy and often desirable to circumvent it. They began with powerful reasons, grounded in well-established constitutional values and institutional role conceptions, to resist a demand that they accord agency decisions inore deference than those decisions warranted. To these motives for resistance, the opinion's language added many opportunities for principled evasion. This combination of features, we predicted, would probably neutralize any significant behavioral effect of Chevron.

This expectation resonates with a larger controversy within the acadeiny, one that extends well beyond administrative law to the very nature of all law. In recent years, scholars associated with the Critical Legal Studies moveinent have emphasized that legal doctrine is "indeterminate" in the sense that it does not constrain judges in their resolution of disputes. These "law skeptics" argue that because legal rules are "sufficiently ambiguous or internally contradictory to justify any result we can imagine," judges can use it to rationalize decisions reached on other, usually undisclosed grounds. ${ }^{120}$

This claim, law skeptics acknowledge, is at bottom an empirical one, ${ }^{121}$ and it has implications that can be tested. At least in its strong form, the claim implies that doctrinal changes such as Chevron should not affect the pattern of results reached in subsequent cases by lower courts, provided that tle judges' personal and political predilections remain essentially unchanged during the period under study. ${ }^{122}$ Because we drew our cases from two time periods that bracket Chevron and are separated from each other by less than one year, our dataset would seem to satisfy that proviso and permit us to test that implication of the law skeptics' claim.

a. The outcomes effect. We began by testing for what we call the "outcomes effect"-Chevron's effect upon the distribution of appellate court outcomes. To do so, we analyzed the proportions of the total number of administrative cases that were affirmed, reversed, remanded,

119. See, e.g., Cardoza-Fonseca v. INS, 767 F.2d 1448 (9th Cir. 1985) (court held Board of Immigration Appeals applied an incorrect legal standard by applying a "clear probability" standard instead of a "well-founded fear" standard in aliens' claims for asylum), aff'd, 480 U.S. 421 (1987).

120. Singer, The Player and the Cards: Nihilism and Legal Theory, 94 YALE L.J. 1, 19-20 (1984); see also Tushnet, Following the Rules Laid Down: A Critique of Interpretivism and Neutral Principles, 96 HARV. L. REV. 781, 819 (1983).

121. Singer, supra note 120 , at 10 .

122. Our own version of the law skepticism claim is generally weaker, although as applied to administrative law it led us to essentially the same prediction about the effect of Chevron. See supra text accompanying notes 111-19. 
or had some other disposition both before and after Chevron. The results of this analysis are presented in Tables 3 and 4 below:

Table 3: Distribution of OUtcomes-Chi Square Test

\begin{tabular}{lrrrr} 
& \multicolumn{2}{c}{1984} & & \\
& Observed & Percent & Expected & $(\mathrm{O}-\mathrm{E})^{2} / \mathrm{E}$ \\
\hline Affirmed & 523 & $70.9 \%$ & 561.38 & 2.62 \\
Reversed & 106 & $14.4 \%$ & 79.89 & 8.54 \\
Remanded & 106 & $14.4 \%$ & 84.25 & 5.61 \\
Other & 25 & $3.4 \%$ & 34.49 & 2.61 \\
Total & 760 & $102.98 \%$ & & \\
No. Cases & 738 & & &
\end{tabular}

1985

\begin{tabular}{lcrcc} 
& Observed & Percent & Expected & $(\mathrm{O}-\mathrm{E})^{2} / \mathrm{E}$ \\
\hline Affirmed & 763 & $81.3 \%$ & 724.62 & 2.03 \\
Reversed & 77 & $8.2 \%$ & 103.11 & 6.61 \\
Remanded & 87 & $9.3 \%$ & 108.75 & 4.35 \\
Other & 54 & $5.8 \%$ & 44.51 & 2.02 \\
Total & 981 & $104.58 \%$ & & \\
No. Cases & 938 & & & \\
$\mathrm{X}^{2}=34.40$ & $\cdot$ & & & \\
{$\left[3\right.$ df: if $\mathrm{X}^{2}>$ 11.34, $\mathrm{p}<.011$} & & & & \\
& & &
\end{tabular}

Table 3 shows a pronounced change in the appellate court dispositions of agency cases after Chevron. Remands, which constituted $14.4 \%$ of total dispositions in the 1984 dataset, dropped to $9.3 \%$ in $\mathbf{1 9 8 5}$. This change, which is shown graphically in Chart 11, amounts to more than a $40 \%$ decrease in the frequency of remands (after normalizing for caseload growth between 1984 and 1985). (See Table 4.)

Table 4: Change in Distribution of Outcomes

\begin{tabular}{|c|c|c|c|}
\hline \multicolumn{4}{|c|}{$1984 / 1985$} \\
\hline & Change & \% Chng (Abs.) & $\%$ Chng (Norm.) \\
\hline Affirmed & 240 & $31.5 \%$ & $14.8 \%$ \\
\hline Reversed & -29 & $-37.7 \%$ & $-42.8 \%$ \\
\hline Remanded & -19 & $-21.8 \%$ & $-35.4 \%$ \\
\hline Other & 29 & $53.7 \%$ & $69.9 \%$ \\
\hline
\end{tabular}




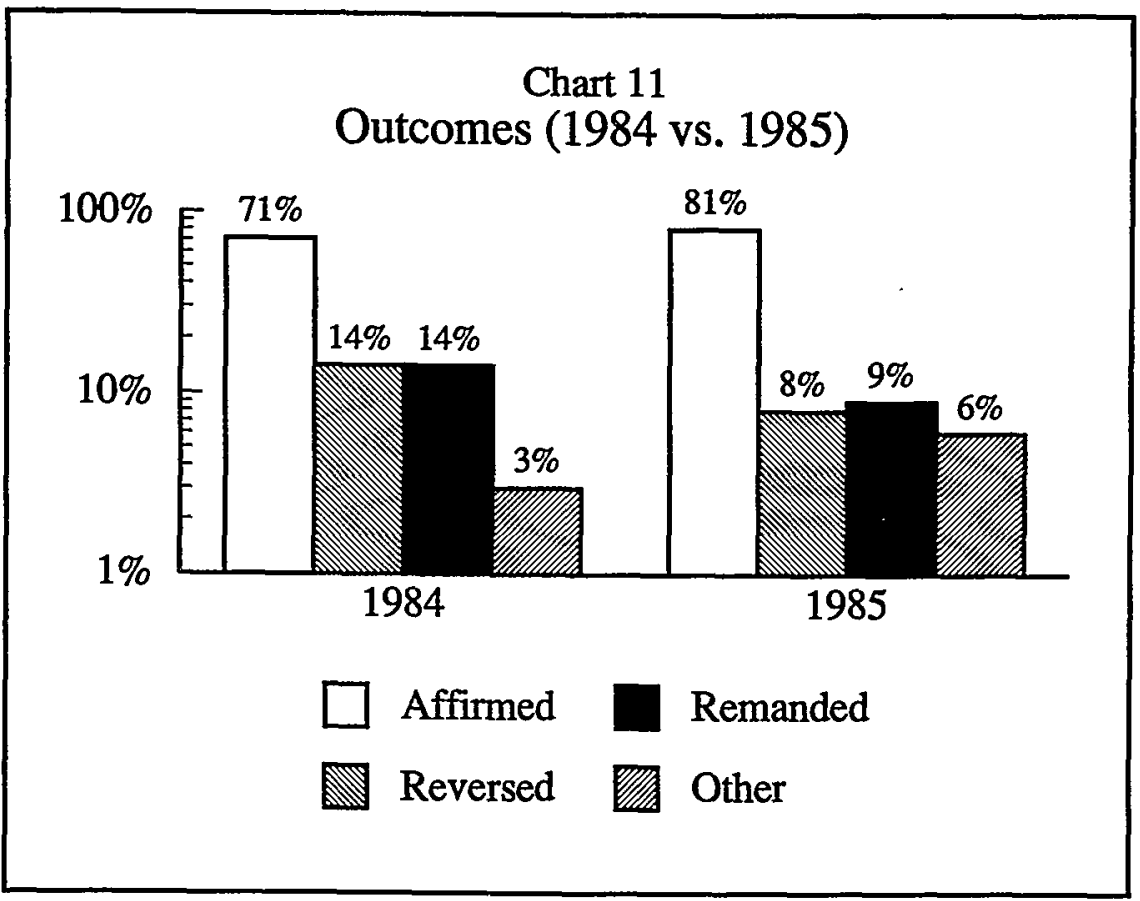

This striking finding led us to ask two additional questions. First, we wanted to know about what we call the "outcome displacement effect." Since there was a pronounced decrease in the proportion of cases remanded after Chevron, where did the "missmg remands" go? Did they becoine affirmances, reversals, or something else? Second, we wanted to know about what we call the "reasons displaceinent effect." Of those remands that remained, what was the distribution of the different reasons for the remands-law, fact, or rationale-and how did that distribution of reasons compare to the pre-Chevron distribution?

b. The outcome displacement effect. Returning to Table 3 above, it can be seen that not only did remands decrease, but reversals also decreased by a comparable ainount, and affirmances imcreased. Betwecn 1984 and 1985, affirmances in toto increased from $70.9 \%$ of the cases to 81.3\%. As shown in Table 4, inore of the mcrease in the number of affirmances was attributable to a reduction in the number of reversals (down 29 cases), than to a reduction in the number of remands (19 fewer cases). This distribution is fully consistent with the logic of Chevron: Although a court rarely, if ever, reverses on a ground other than an error of law, remands can be justified more easily on alternative grounds.

The differences in the distribution of outcomes in the 1984 and 1985 datasets are shown graphically in Chart 11. $A$ chi square $\left(X^{2}\right)$ test for 
statistical significance is included in Table 3 above. It shows that the differences in the distributions of results between the 1984 and 1985 datasets are statistically significant at well above the $99 \%$ confidence level.

As a further way to assess our results, we graphed the data on a month-by-month basis. (Sce Chart 12.) This shows rennarkable consistency in the percentages of cases affirmed (rather than reversed or remanded) throughout both periods. In none of the six inonths during 1984 that we studied did the percentage of affirmances approach even the level for the inonth with the lowest number of affirmances during 1985. This strongly suggests a systematic difference between the 1984 and 1985 datasets. Chart 12 also appears to exclude seasonal variation in the reporting of cases as a possible confounding factor.

c. The reasons displacement effect. We have seen that our data on the outcoines effect tend to refute one inajor implication of the strong version of the law skeptics' claim, as Chevron significantly altered the proportion of agency cases affirmed by the appellate courts over a period of time during which judicial inenbership and preferences apparently were stable. Our data also enabled us to test another implication of that claim. On its face, the Chevron decision appeared to inake it nore difficult for a reviewing court to reverse or reinand an administrative decision for an error of law in construing a statute. ${ }^{123}$ If the skeptics were correct, post-Chevron courts imight try to maximize their residual power to reinand by avoiding rehiance upon substantive law-based remands (and reversals)-the only type that Chevron had discouraged-and by relying instead upon remands on procedural, fact-based, rationale-based, or unstated grounds, situations to which Chevron did not expressly apply. We call this the "reasons displacennent" effect.

To learn whether the Chevron decision caused judges to alter the grounds on which they rationalized their decisions to remand, we coded all the reported cases that reinanded administrative decisions during a six-month period in 1984 prior to Chevron, and during a six-month period in 1985 after Chevron, into five categories:124 (1) remands for errors of substantive law; (2) reinands for errors of procedural law; (3) remands

123. The so-called Chenery doctrine in administrative law holds that courts should normally remand for reconsideration by the agency those decisions that are based on errors of law rather than reverse the agency outright. The remand permits the agency to consider whether as a discretionary matter the agency wishes to alter its result or supply an alternative rationale for it. See generally Friendly, supra note 33 (exploring the scope that courts have attributed to Chenery); Weaver, Chenery II: A Forty Year Retrospective, 40 ADMIN. L. REv. 161 (1988) (examining the current status of Chenery II).

124. An individual case, of course, might be assigned to more than one category. 


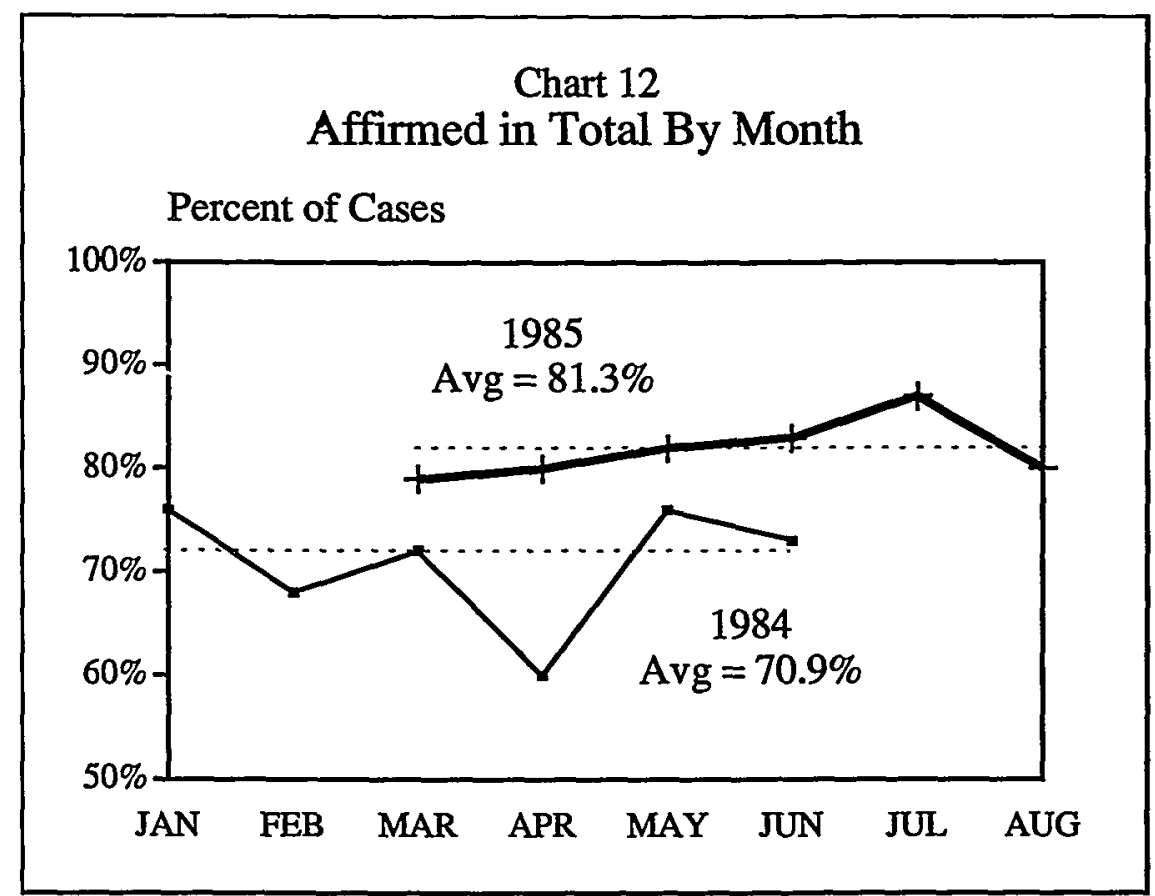

for lack of adequate factual support; (4) remands for lack of adequate explanation; and (5) remands for which no basis is given for the court's action (e.g., table decisions). As shown in Table 5, which follows, movement froin reliance upon substantive law in favor of the other grounds for remand did occur after Chevron.

TABle 5: ReAsons For ReMAND

\begin{tabular}{lrrrrr} 
& \multicolumn{2}{c}{1984} & \multicolumn{2}{c}{1985} & \multicolumn{1}{c}{$84 / 85$} \\
& \# & \multicolumn{1}{c}{$\%$} & \# & \multicolumn{1}{c}{$\%$} & \% Change (*) \\
\hline Law-Substance & 38 & $35.8 \%$ & 19 & $21.8 \%$ & $-39.1 \%$ \\
Law-Procedure & 16 & $15.1 \%$ & 15 & $17.2 \%$ & $14.2 \%$ \\
Fact-Based & 30 & $28.3 \%$ & 28 & $32.2 \%$ & $13.7 \%$ \\
Rationale & 19 & $17.9 \%$ & 18 & $20.7 \%$ & $15.4 \%$ \\
Unstated & 19 & $17.9 \%$ & 20 & $23.0 \%$ & $28.3 \%$ \\
Total & 122 & $115.1 \%$ & 100 & $114.9 \%$ & \\
No. Cases & 106 & & 87 & & \\
* Normalized & & & & &
\end{tabular}

As can be seen froin the percentage change ("\% Change") column in Table 5, there is a pronounced (39\%) decrease in the proportion of remands that rely on errors of substantive law as a reason for remand. Although the other grounds for remand, including the absence of a stated reason, imcreased their percentage shares of the total, the actual 
numbers of cases in these categories remained remarkably constant. Thus, there was virtually no change in the total number of remands for procedural errors between 1984 and 1985, but due to the smaller total number of remands in 1985, the percentage of cases remanded for other reasons actually increased. The distribution of reasons for reinands and the percentage changes in that distribution between the 1984 and 1985 datasets are shown graphically in Chart 13.

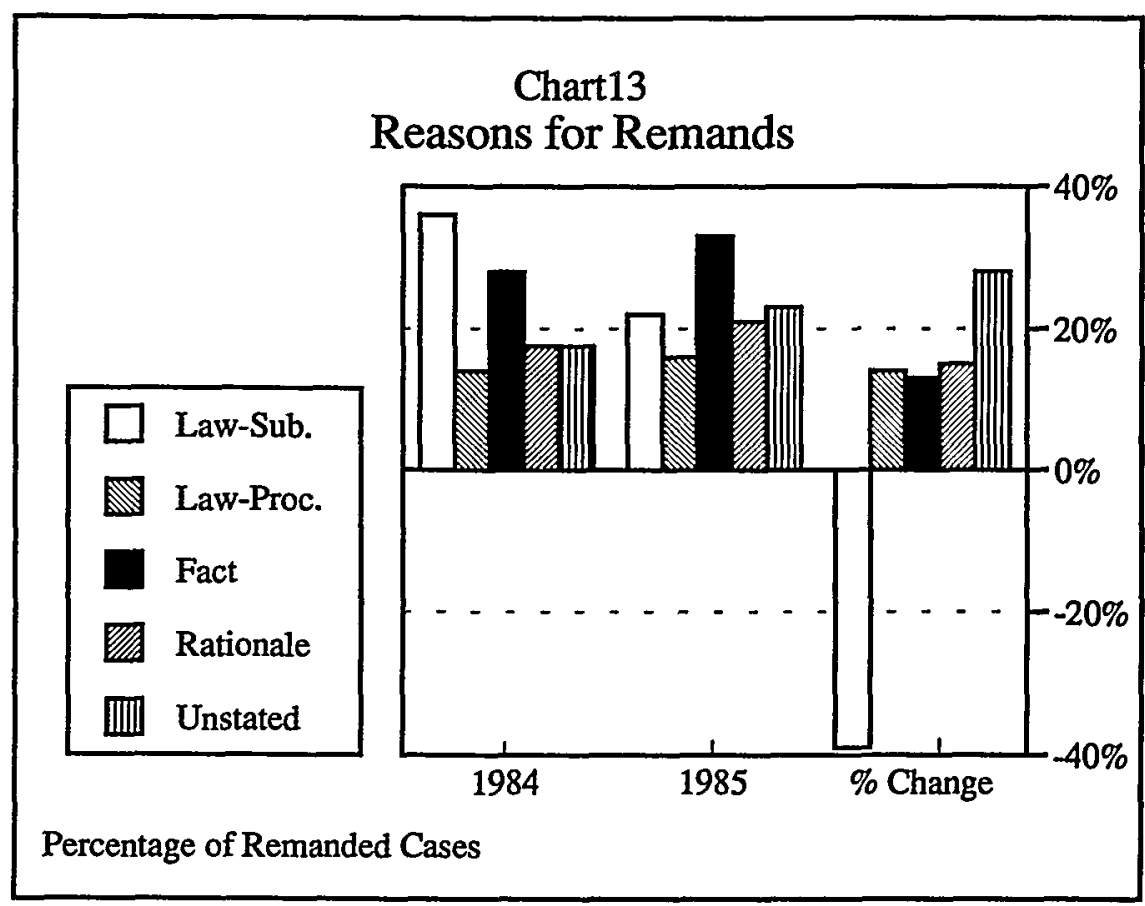

To determine whether these changes in the reasons for remands are statistically significant, a chi square $\left(X^{2}\right)$ test was performed. As shown in Table 6, the comparison is not statistically significant with respect to the variation in the distribution of reasons for remands as a whole. However, when the contingency table was restructured to compare remands based on substantive law versus all other reasons, this comparison was found to be statistically significant at above the $95 \%$ confidence level. (See Table 7.) The effect on substantive remands is shown graphically in Chart 14 and these results strongly suggest that Chevron discouraged remands based on substantive law. The postChevron "shice" representing remands for substantive reasons is much smaller than the pre-Chevron stice for two reasons-fewer reinands overall and a smaller proportion of remands being made on the grounds of an error of substantive law. 
Table 6: Reasons for Remand—Chi Square Test

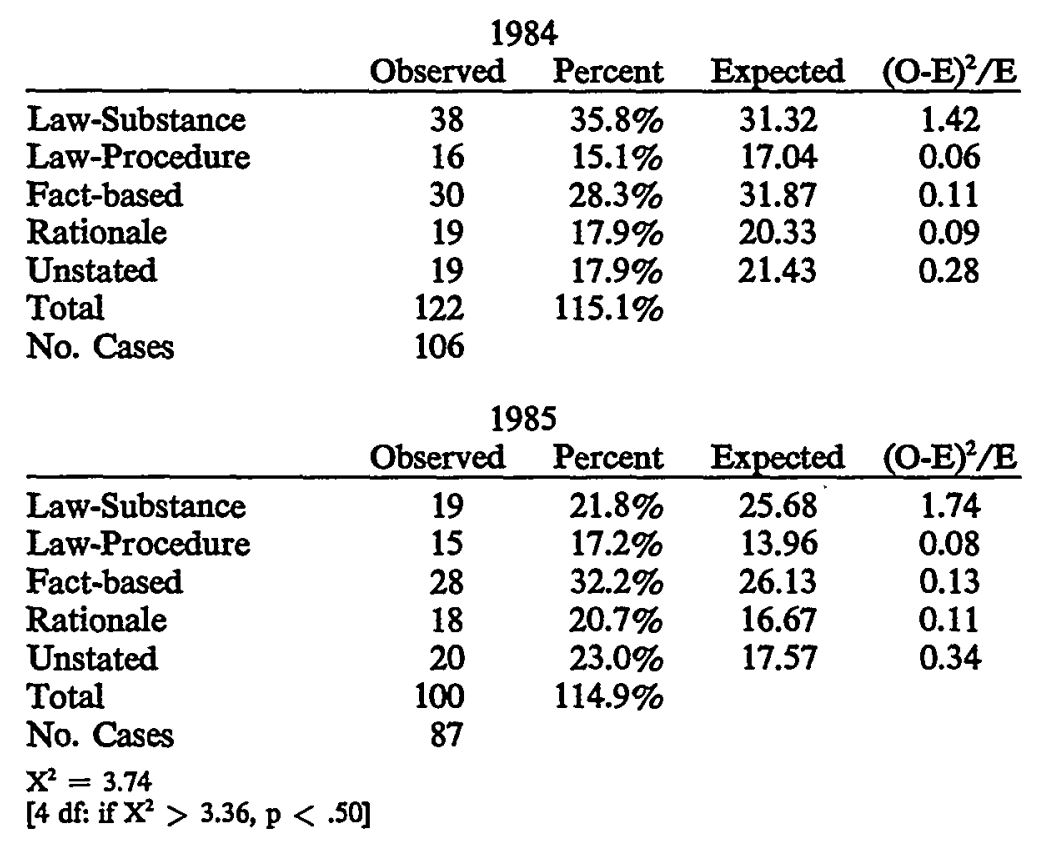

TABle 7: Reasons For Remand-ChI SQUARE TeST 1984

\begin{tabular}{lcccc} 
& Observed & Percent & Expected & $(\mathrm{O}-\mathrm{E}-.5)^{2} / \mathrm{E}$ \\
\hline Law-Substance & 38 & $31.1 \%$ & 31.32 & 1.22 \\
Other & 68 & $55.7 \%$ & 74.74 & 0.70 \\
Total & 106 & & &
\end{tabular}

\begin{tabular}{lcccc} 
& & 1985 & & \\
& Observed & Percent & Expected & $(\mathrm{O}-\mathrm{E}-5)^{2} / \mathrm{E}$ \\
\hline Law-Substance & 19 & $19.0 \%$ & 25.68 & 2.01 \\
Other & 68 & $55.7 \%$ & 61.26 & 0.64 \\
Total & 87 & & & \\
$\mathrm{X}^{2}=4.56$ & & & & \\
{$\left[1\right.$ df: if $\left.\mathrm{X}^{2}>3.84, \mathrm{p}<.05\right]$} & & &
\end{tabular}

Overall, our analysis tends to contradict the law skeptics' prediction. Our data indicate that subsequent decisions were being shaped by Chevron's strong "outcomes" and "outcome displaceinent" effects. Our aggregate data are at their most ambiguous with respect to the existence of a "reasons displaceinent" effect. The total number of reinands based on grounds other than substantive law was constant, but this total increased as a percentage of all reinands. We cannot rule out the possibility that soine courts inay have responded to Chevron strategically 


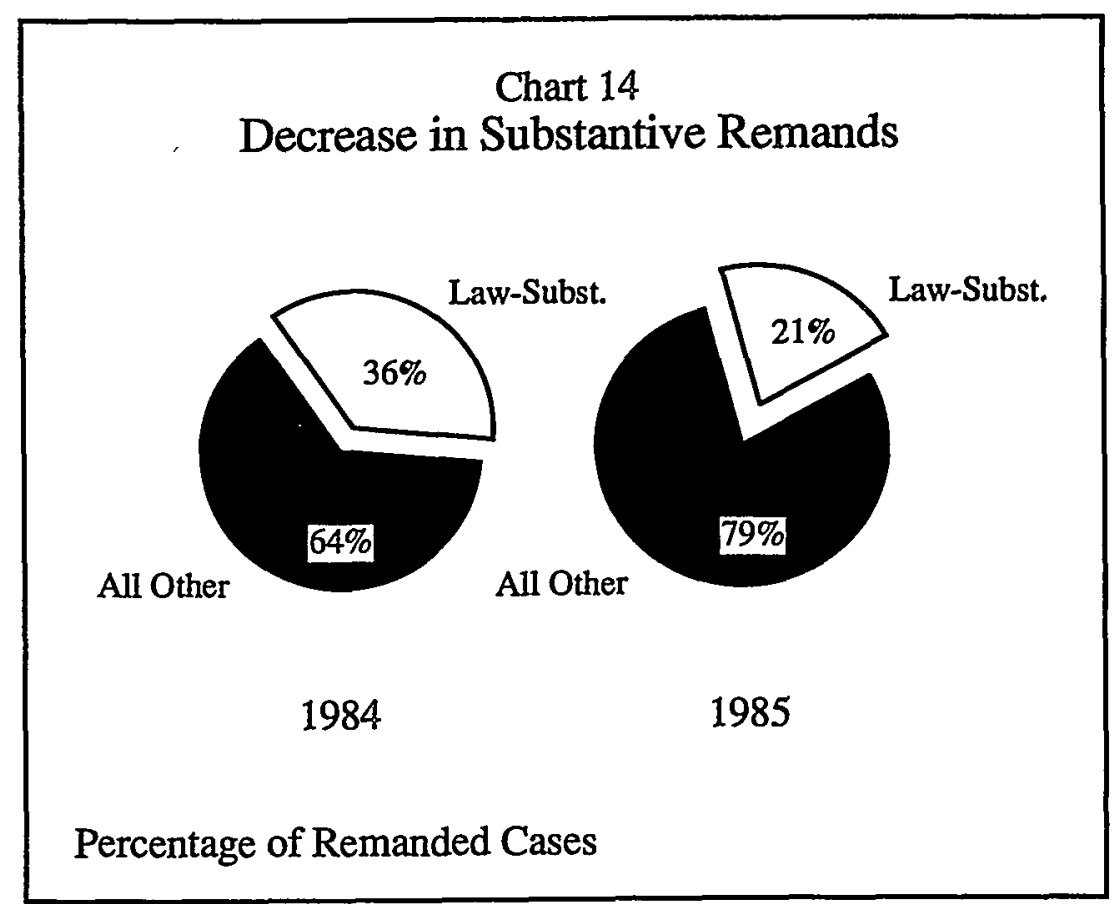

by exploiting the leverage that remained available to them ${ }^{125}$-their residual power to select the particular reasons for the remand. Indeed, our separate analysis of the effects of Chevron on the D.C. Circuit 126 strongly suggests that some courts may have tried to circumvent that doctrinal change. These effects, however, do not show up as clear evidence of a "reasons displacement" effect in the aggregate data. All that fairly may be said based on the aggregate data is that there was a dramatic decrease in substantive law remands following Chevron, and that the number of remands im other categories remained constant. This is strong evidence that Chevron changed the overall distribution of outcomes, but it does not exclude the possibility that the intended effect of a new rule can be avoided or blunted in some individual eases.

3. Persistence of Effects. The striking disparities in the rates of remands and reversals between the 1984 and 1985 datasets and the shift in grounds for remands in the wake of Chevron led us to wonder whether the effects that we had observed would be temporary or persistent. We thought that good arguments could be made for either prediction.

125. See, e.g., K. Llewellyn, The Bramble BuSh 186 (1951) (concerning the "leeways" available to judges who want to avoid constraints of precedents or the tendency of appellate courts to shift the content and direction of authorities when applying them to new circumstances).

126. See infra Part $\operatorname{III}(\mathrm{C})(4)$. 
The simplest, most straightforward hypothesis based on our comparison of the 1984 and 1985 data was that the post-Chevron changes would endure. If the lower courts were willing to follow Chevron (as our analysis of the 1985 data indicated they clearly were), one of their most powerful weapons for overruling agencies-their ability to impose a judicial interpretation of the statute-had been disarmed. In addition, Chevron seemed to comport with the long-term trends in American administrative law toward increasing deference to agency lawmaking. ${ }^{127}$

On the other hand, we also could easily imagine several reasons why the post-Chevron changes might not endure. The passage of time itself might erode the effects we had observed shortly after Chevron. Perhaps lower courts are relatively sensitive to doctrinal changes in the immediate wake of a Supreme Court deeision, but the impact of the change may be attenuated over time as new eases and other issues gain prominence, and as lower courts learn to write remand opimions that satisfy Chevron's requireinents. If this hypothesis were true, then one would expect that remand and reversal rates gradually would drift back toward their longterin historical averages. A variation of this "regression toward the mean" hypothesis turns on what political scientist Carl Friedrich called the "rule of anticipated reactions." 128

A third, alternative hypothesis would predict some decrease in agency success rates between 1985 and 1988, not because of anticipated reactions, but beeause the law itself changed after Chevron. Between 1985 and 1988, the Supreme Court appeared to recede from the position of extreme deference to agency constructions that it had seemed to endorse in Chevron and its immediate progeny. ${ }^{129}$ The most prominent of these deeisions was INS v. Cardoza-Fonseca, ${ }^{130}$ decided in 1987. Over Justice Antonin Scalia's strong objection in his concurrence that the majority's approach was "not an interpretation but an evisceration of Chevron," 131 the Court in Cardoza-Fonseca reasserted judicial supremacy as

127. See, e.g., Mashaw, Pro-Delegation: Why Administrators Should Make Political Decisions, 1 J.L. ECON. \& ORG. 81 (1985) (proposing that broader delegation of power to agencies actually improves governmental responsiveness).

128. C. Friedrich, Constitutional Government and Politics: Nature and DevelOPMENT 588-89 \& n.117 (1941).

129. See generally Hirshman, Postmodern Jurisprudence and the Problem of Administrative Discretion, 82 Nw. U.L. REv. 646, 688-703 (1988) (discussing, post-Chevron caselaw as failing to effect a revolution in "the relationship between courts and agencies").

130. 480 U.S. 421 (1987); see also NLRB v. United Food \& Commercial Workers Union, Local 23, 484 U.S. 112, 125 (1987) (Courts' task "under Cardoza-Fonseca and Chevron, is not judicially to categorize each agency determination, but rather to decide whether the agency's regulatory placenent is permissible.").

131. Cardoza-Fonseca, 480 U.S. at 454 (Scalia, J., concurring in the judgment). 
"the final authority on issues of statutory construction,"132 at least where "traditional tools of statutory construction" may be employed to determine the statute's meaning. 133

In order to determine whether the observed changes in reversal and remand rates in the wake of Chevron were indeed transitory, we expanded our study to include a two-month period in the then-inost recent advance sheets (covering cases deeided during March and April, 1988). Although this dataset of 1988 cases was only about one-quarter the size of the dataset of 1985 cases, we hoped that comparing the two wonld allow us to assess the durability of Chevron's effects on appellate court behavior.

Table 8, which follows, analyzes the pattern of results during the two month period in 1988 as coinpared to the 1985 sample period. The 1988 data show an affirmance rate of 75.5\%; this is roughly halfway between the pre-Chevron affirmance rate of $70.9 \%$ and the post-Chevron affirmance rate of $81.3 \%$. (See Chart 15.) Because the differences in outcomes betwecn the 1988 and 1985 datasets are statistically significant at the $99 \%$ confidence level, we can say with a high degree of certainty that they are not merely the resnlt of randoin statistical variation.

We cannot say with a similar level of confidence, however, why the 1988 outcomes are different from those in 1985 . It is very tempting to conclude that the refinement of the legal doctrine in post-Chevron cases such as Cardoza-Fonseca produced a corresponding adjustment in agency success rates. ${ }^{134}$ This suggests the tantalizing hypothesis that over a large number of cases the resnlts of judicial review may be far inore sensitive to subtle changes in legal doctrine than we had anticipated. Unfortunately, our analysis does not permit us to test this hypothesis, for we cannot exclude the possibility that the passage of time, other changes in legal doctrine, the changing composition of the judiciary, or some other confounding factor inay account for the observed changes in agency success rates between Chevron and early 1988 . We

132. Id. at 447 (quoting Chevron, U.S.A., Inc. v. NRDC, 467 U.S. 837, 843 n.9 (1984)).

133. Id.

134. Recent Supreme Court cases consider the Chevron standard of review to be well-established precedent. However, the unanimous agreement on the Chevron standard has not prevented disagreement on how the standard should be applied in particular cases. See, eg., Sullivan v. Everhart, 110 S. Ct. 960 (1990) (Supreme Court reversed decision by court of appeals after finding that the Department of Health and Human Services' regulations were based on a reasonable construction of the Social Security Act); Dole v. United Steelworkers, 110 S. Ct. 929 (1990) (Supreme Court affirmed the judgment of the Third Circuit after finding that the clear congressional intent of the Paperwork Reduction Act was to prevent the OMB from reviewing agency disclosure rules). Judicial divergence in applying the Chevron standard has led one D.C. Circuit judge to comment recently that courts often imvoke Chevron merely to give "lip service to deference." Silberman, Chevron-The Intersection of Law and Policy, 58 GeO. WASH. L. REV. 821, 826 (1990). 
Table 8: Distribution of OUtcomes-ChI Square Test

1988

\begin{tabular}{cccc} 
Observed & Percent & Expected & $(\text { O-E })^{2} /$ E \\
\hline 111 & $75.5 \%$ & 116.58 & 0.27
\end{tabular}

Affirmed

Reversed

Remanded

Other

Total

No. Cases

12

25

$8.2 \%$

11.87

0.00

$\begin{array}{rr}8.2 \% & 11.87 \\ 17.0 \% & 14.94\end{array}$

6.77

$3 \quad 2.0 \%$

$151 \quad 102.72 \%$

7.60

2.79

147

1985

\begin{tabular}{lrrrr} 
& \multicolumn{2}{c}{1985} & & \\
& Observed & Percent & Expected & $(\text { O-E })^{2} / \mathrm{E}$ \\
\hline Affirmed & 763 & $81.3 \%$ & 757.42 & 0.04 \\
Reversed & 77 & $8.2 \%$ & 77.13 & 0.00 \\
Remanded & 87 & $9.3 \%$ & 97.06 & 1.04 \\
Other & 54 & $5.8 \%$ & 49.40 & 0.43 \\
Total & 981 & $104.58 \%$ & & \\
No. Cases & 938 & & & \\
$\mathrm{X}^{2}=11.34$ & & & & \\
{$\left[3\right.$ df: if $\left.\mathrm{X}^{2}>11.34, \mathrm{p}<.01\right]$} & & & &
\end{tabular}

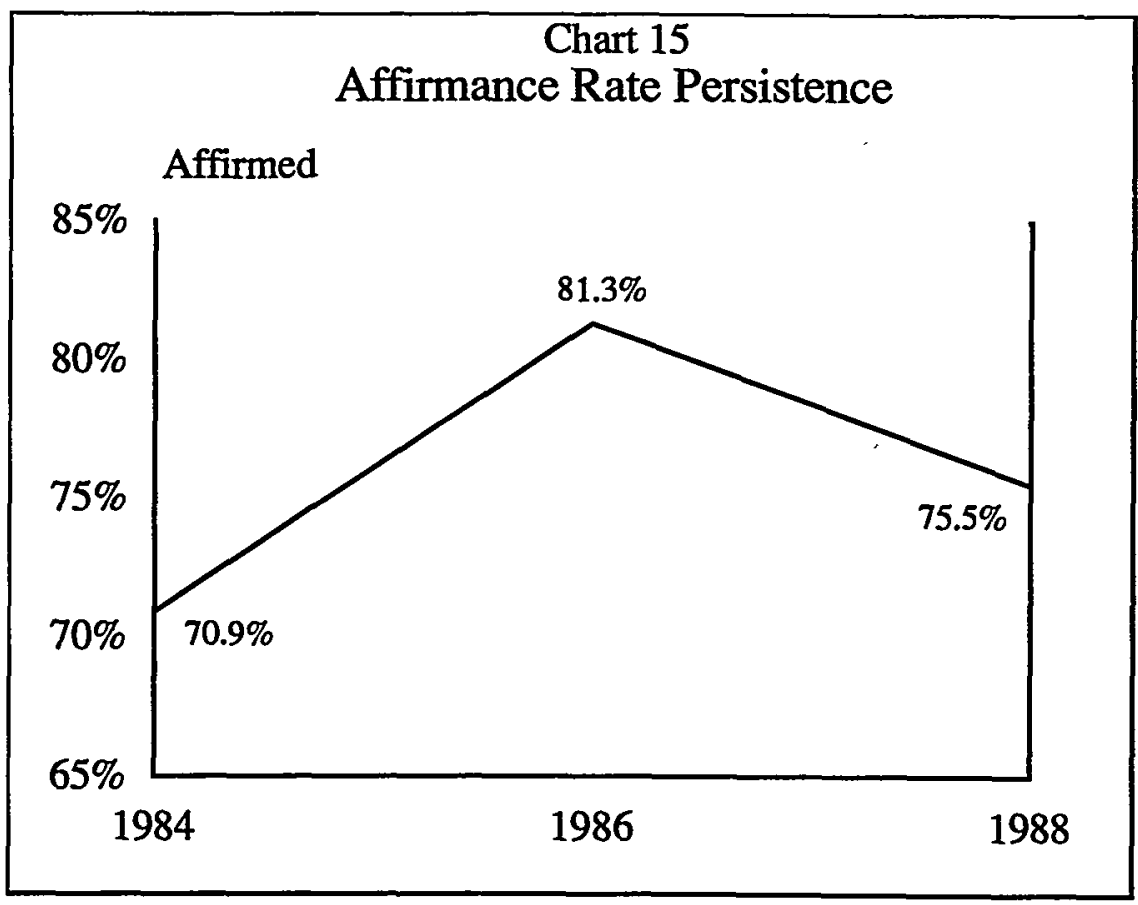


can say with some certainty, however, that the 1988 agency success rate was lower than the 1985 agency success rate and that this difference was not merely a random statistical variation.

The most striking difference that emerges from the 1988 and 1985 datasets is a pronounced mcrease in the percentage of cases remanded. As shown in Table 8 above, remands in 1985 accounted for only $9.3 \%$ of cases; by 1988 the percentage of cases remanded had almost doubled to $17.0 \%$. When normalized to adjust for difference in the size of the datasets, the frequency of remands mcreased by $83.4 \%$ from 1985 to 1988, as shown in Table 9, which follows.

Table 9: Change in Results (1988 vs. 1985)

\begin{tabular}{lc} 
& $\%$ Change (Norm.) \\
\hline Affirmed & $-7.2 \%$ \\
Reversed & $-0.6 \%$ \\
Remanded & $+83.4 \%$ \\
Other & $-64.6 \%$
\end{tabular}

We had expected that Chevron wonld induce courts to increase the frequency of remands, rather than outright reversals. By 1988, courts were indeed remanding more frequently than they had done in 1985, immediately after Chevron. Most of the increased remands, however, were not displacing reversals (which remained unchanged); they were displacing "other" dispositions. Unfortunately, the data for 1988 are too limited to allow us to say anything definitive about changes in the grounds for remands. But courts' imcreasing propensity to remand suggests that within a few years of Chevron, the increase im remands that we had predicted took place after all; it sunply occurred somewhat later than we had anticipated. We also expected a "reasons displacement" effect, whereby courts would shift from substantive law-based reversals and remands, to remands on other grounds, ${ }^{135}$ but the number of remands in our 1988 dataset was too small to derive significant conclusions on this issue.

When we factor into our analysis the longer-term perspective provided by the 1988 data, the following picture emerges: Within a few months after Chevron, the affirmance rate rose substantially, while reversals and remands decrcased almost equally to account for the increased affirmance rate. Over the longer term, however, remands gradually returned to, and then exceeded, their pre-Chevron levels, eroding about half of the increase in affirmances that Chevron had

135. See supra text accompanying notes 123-26 (discussion of the "reasons displacement" effect). 
produced. Outright reversals remained infrequent. These changes are presented graphically in Chart 16.

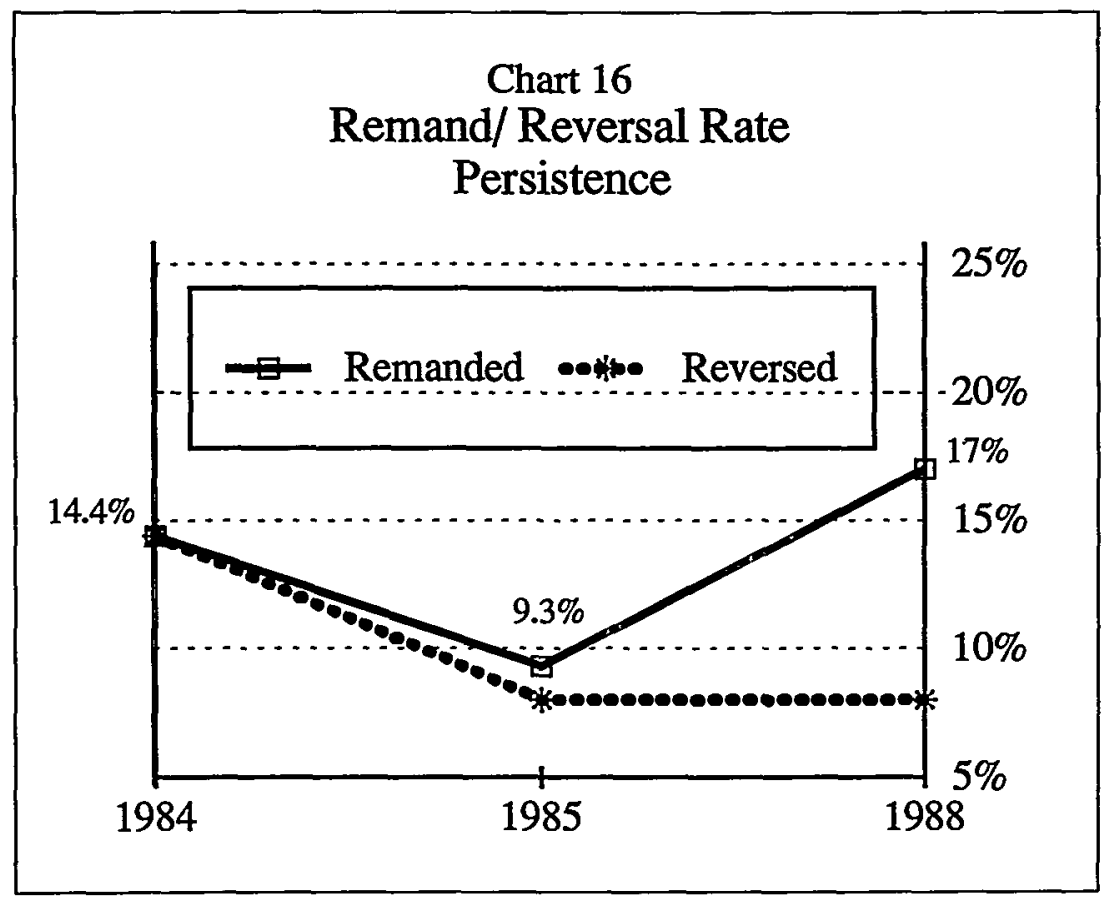

4. Court-Specific Effects. So far, we have discussed the issue of the "effects of Chevron" as if the federal courts were a monolith. The organization of our datasets, however, permits us to make comparisons to assess whether particular courts or categories of cases are consistent with or run counter to the national trends. A particularly interestimg example of how aggregate data may be misleading involves the D.C. Circuit's behavior in the wake of the Chevron decision. Chart 17 coinpares historical rates of affirmance im administrative law cases in the D.C. Circuit with the comparable rates in the circuit courts as a whole (including the D.C. Circuit). Chart 17 shows that the affirmance rates in the D.C. Circuit were similar to the aggregate affirmance rate for all circuit courts in 1965 and 1975. By the mid-1980s, however, a striking disparity had developed. On the eve of the Supreme Court's 1984 decision in Chevron, the D.C. Circuit was affirming only $58.6 \%$ of administrative law cases, compared to a national circuit court average of $70.9 \%$. This difference inay im part reflect the fact that the D.C. Circuit handles more of the complex, mnltiple-issue rulemakings, which are affirmed less often. ${ }^{136}$

136. See supra text accompanying notes $89-92$ and Chart 10 . 
But the disparity also suggests that the extra "hard look" in administrative law cases that is sometimes attributed to the D.C. Circuit was indeed occurring in the mid-1980s just before Chevron was decided.

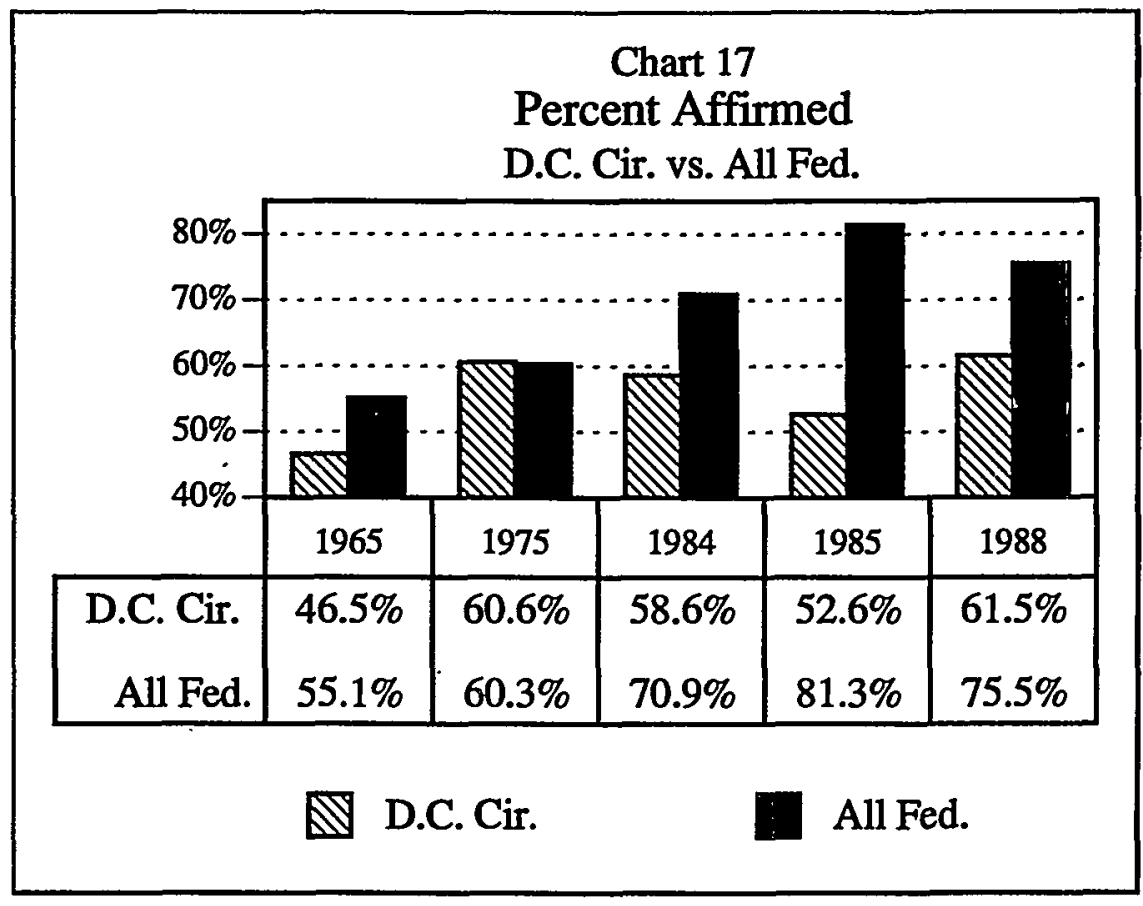

We are tempted to speculate that the relatively low affirmance rate for administrative law cases in the D.C. Circuit may have been one inotive for the Supreme Court's clear message in Chevron that lower courts should defer more to agency constructions of statutes. When we coinpare the D.C. Circuit's affirmance rate with the national circuit court average in 1985, just after Chevron, we find that the Supreine Court's message did not immediately induce greater deference by the D.C. Circuit. Between 1984 and 1985, while the national average affirmance rate rose from $70.9 \%$ to $81.3 \%$, the affirmance rate in the D.C. Circuit actually declined from $58.6 \%$ to $52.6 \%$. Further analysis using our research methodology could shed hight on the particular techniques that the D.C. Circuit used to buck the national post-Chevron trend of increasing deference, although our dataset may be too sinall to permit drawing statistically significant conclusions on this issue. In any event, by 1988 the gap between the D.C. Circuit and the other circuit courts had narrowed (61.5\% versus $75.5 \%$ ). Still, affirmance rates reinained almost $15 \%$ lower in the D.C. Circuit than the average for the other circuits. 
5. Agency-Specific Effects. The data on agency-specific success rates yield another significant finding: For most agency groups, the data suggest a pronounced outcome displacement effect in the wake of Chevron. For example, the proportion of the cases in the residual category that were affirmed in toto increased from $52 \%$ to $78 \%$ between the preand post-Chevron periods. The affirmance rate for the health, safety, and environmental agency grouping; the NLRB; and the Patent and Trademark Office also incrcased substantially between those periods. But this pattern was not evident for all agency groupings. For two of them (immigration and "other regulatory"), the success rate actually declined (albeit only shightly) after Chevron. The "Chevron effect," it appears, is an even inore complex phenomenon than we have suggested.

If we look instead at the agency "failure rate," defined as the proportion of cases in which the reviewing court simply reversed, thus depriving the agency of any further opportunity to succeed, ${ }^{137}$ similar patterns are revealed. The failure rate varied considerably from grouping to grouping; it ranged from $13.5 \%$ in the residual category to $2.3 \%$ for agencies in departinents other than Labor. If anything, the Chevron effect was even stronger when this ineasure was used; the failure rates of several groupings' declined substantially (for health, safety, and environinental agencies, from $28 \%$ to $6 \%$; and for the NLRB, from $19 \%$ to $5 \%) .138$

\section{What Happens After Remand?}

Judicial opmions are stories-albeit elaborate, highly stylized ones-and only the most unimaginative reader of opimons could finish them without wondering how the stories actually end.139 Courts in administrative law cases are especially likely to pique our curiosity when, forswearing their power to resolve the dispute themselves, they instead remand it to the agency to write the story's conclusion. In such cases we naturally want to know about the dénoueinent. Specifically, we ask: What did the agency do procedurally once it got the case back? What was the outcome, and did the court's intervention really matter? How long did the proceedings take after remand? And were there intervening

137. As we pointed out, see supra note 44 , some double counting was inevitable under our coding system because a case that was reversed in part and either affirmed in part or remanded in part was coded as both a reversal and as soinething else.

138. Again, two groupings seemed to controvert the Chevron effect, although both changes were very sinall. The failure rates of immigration cases increased from $4 \%$ to $5 \%$, and the MSPB's rate increased from $2.9 \%$ to $3.1 \%$.

139. See, e.g., J. NoONan, Persons and Masks of the LAW (1976); A. Lewis, Gideon's Trumpet (1964); P. Schuck, Agent Orange on Trial: Mass Toxic Disasters in the CourTs 255-57 (1986). 
events that affected the outcome? Taken together, these questions pose what is probably the least studied but most important issue surrounding administrative law: What difference does judicial review of agency action make?

Unfortunately, our study cannot resolve this issue definitively. Our data on post-remand events, which relate to the $1984-85$ period, consist entirely of the responses of the parties' lawyers to a questionmaire and follow-up telephone interviews. These data are, therefore, inevitably impressionistic. In addition, the lawyers may have tended to put a somewhat better (from their chents' perspective) face on the outcomes than more detached observers would. ${ }^{140}$ Nevertheless, the data do permit us to shed some light on some of the empirical questions noted above.

1. Post-Remand Procedures. We began with some general hypotheses concerning what happens procedurally once a case is returned to an agency. First, we expected that many remands would lead to informal settlements or withdrawals. The delay incident to any remand, together with the further agency proceedings that a remand might necessitate, could be so costly that the parties would seek a cost-minimizing alternative to continued litigation. More generally, remand decisions would almost certainly alter the parties' prospects, bargaining positions, and incentives to litigate. ${ }^{141}$ Second, the reasons displacement effect that we found should support the hypothesis that agencies to which cases were remanded in the post-Chevron period would hold additional hear-

140. This bias could not be entirely overcome (and may even have been compounded in some cases) by our technique of asking the lawyers on both sides- "agency" and "petitioner"-the identical questions about each of the remanded cases. (Our convention was to label the party opposing the agency as "petitioner" even when it was the agency that had petitioned for review of the decision below.)

This technique, however, did reveal persistent discrepancies between the responses of the agency's lawyers and those of the petitioner's lawyers. The discrepancies occurred not only as to questions to which we expected the parties to respond differently (e.g., "Which of the following .. . best describes the practical effect on your chent?"), but also as to those to which we expected their responses to be identical (e.g., procedures after remand; elapsed time). Because these discrepancies generally were quite small (on the order of $5 \%$ or less), we ascribe no particnlar significance to them, but they do present a problem in reporting and analyzing the data. We have chosen to average the petitioner's and agency lawyers' responses on the theory (lacking any better one) that the truth lies somewhere in between. Where particular discrepancies might be of substantive significance, we note them.

Fimally, the crudeness of these data have caused us often to use terms like "roughly" or "about" rather than numerieal pereentages, which should alert readers to the analysis's imprecision on these points.

141. For example, a remand that resolved points of substantive or procedural law or that signaled the court's view of the merits wonld reduce the parties' uncertainty as to the ultimate outcome, while a remand that demanded inore agency fact-finding or justification would increase the cost to the agency of continuing to maintain its earher position. 
ings inore frequently or otherwise supplement the record. The agencies, we supposed, would need to institute such procedures in order to cure the factual or explanatory defects identified by the reviewing courts.

The data confirmed our first hypothesis. The lawyers reported that in about $40 \%$ of the remanded cases in 1985, no further proceedings occurred. ${ }^{142}$ The number of remands that "wash out" in this way increased by about $10 \%$ after Chevron. Among the agency clusters, the NLRB, DOL, and "other regulatory" group were the ones least likely to undertake further post-remand proceedings. This tends to confirm our suspicion that adjudications, which aecounted for virtually all of the NLRB and DOL cases, are easier to settle or drop than other kinds of proceedings.

Our second hypothesis-that remands after Chevron would inore frequently cause the agencies to hold additional hearings or revise the record-was not borue out. Indeed, the opposite was true. Although proceedings of that kind were instituted in roughly $30 \%$ of the remanded cases during the pre-Chevron period, that figure declined to about $18 \%$ in the post-Chevron period. This mystery ouly deepened when we disaggregated the remands in order to focus upon the fact-based and/or rationale-based cases, which were more common after Chevron and were expected to necessitate record-revising procedures after reinand. Contrary to expectations, we found that such procedures were more likely to be employed before Chevron than after. Although the post-Chevron increase in cases that "wash out" probably accounts for some of this decline, we are unable to explain the rest of it.

More generally, the data on post-reinand procedures reveal certain features of the structure of post-remand activity. At a gross level, we can see what happens procedurally. As already mentioned, pre-Chevron about $40 \%$ of the remanded cases prompted no further action while ouly $30 \%$ of the remands (18\% post-Chevron) actually led to procedures in which the administrative record would be revised. The data also indicate that in another $15-20 \%$ of the remands, the ageucy instead issued a new opinion-which usually sought to justify its earlier position by adopting a new legal theory or interpretation-rather than simply supplying additional explanation. The remainder of the cases were coded "other."

142. Our data on post-remand outcoines, discussed in the next subsection, see infra Part III(D)(2), "Post-Remand Outcomes," distinguish between agencies that "agreed to settlement" and agencies that "dropped the proceeding." Unfortunately, the total for these two categories does not equal the total for "no further proceedings after remand." We are uncertain about the sources of this discrepancy. One may be that cases in which the non-agency party dropped the proceeding were coded as "other." Another may be that "no further proceedings after remand" was applied so hiterally as to exclude cases that the agency dropped only after some proceedings had occurred. 
When we disaggregate the post-remand activity data by circuit court, the inost interesting finding is that remands in the D.C. Circuit were less likely to "wash out" than those in all other circuits combined. ${ }^{143}$ It is not at all clear why this should occur unless the greater significance of D.C. Circuit cases makes them inore difficult to settle informally.

2. Post-Remand Outcomes. We began our study with a strong behef in what might be called the "agency gets the last word" hypothesis. That is, we expected that an agency to which a reviewing court remands a case usually will end up reaffirming the position that it originally took.

This hypothesis was grounded $\mathrm{m}$ the same kind of Realist considerations that had led ns (erroneously, as it turned out) to doubt that the Supreme Court's Chevron decision would have much effect on how the courts of appeals disposed of agency cases. Agencies generally make policy decisions for what they think are compelling political, institutional, and programmatic reasons. A court does not eliminate those goals when it remands to the agency; it simply strengthens the agency's incentives to find other ways to achieve them. Whether the agency gets the last word, however, depends not only upon the agency's motivation, but also upon the degree of constraint created by the control techniques available to a remanding court. Courts generally employ these techniques in ways that are designed to allow the agency considerable discretion and flexibility in how to respond to the remand-this flexibility permits agencies to exploit the technical and pohicy expertise for which they were established in the first plaee.

In order for a reviewing court to have the last word, it must either write remand opimions prescribimg quite specifically what the agency may and inay not do with the remanded case, ${ }^{144}$ or engage in repeated remands until the agency complies with the court's wishes. ${ }^{145}$ Unless the court is prepared to adopt one of these strategies, however, it may not be able as a practical matter to prevent the agency from adhering to the agency's original position. ${ }^{146}$ Yet both these strategies are problematic;

143. It was necessary to combine all of the other circuits in order to obtain sufficiently large numbers to make the coinparison meaningful.

144. See, eg., Alabama Power Co. v. Costle, 636 F.2d 323, 357 (D.C. Cir. 1979) (making very specific findings on the interpretation of the Clean Air Act).

145. The classic example, of course, is the Morgan litigation, in which the case returned to the Supreme Court three times after the Court's initial remand. United States v. Morgan, 313 U.S. 409 (1941); United States v. Morgan, 307 U.S. 183 (1939); Morgan v. United States, 304 U.S. 1 (1938); Morgan v. United States, 298 U.S. 468 (1936).

146. Our colleague Harlon Dalton has analyzed the struggle between appellate and trial courts in much the same terms, expressing skepticism about the extent of trial court self-correction resulting from appellate review. Dalton, Taking the Right to Appeal (More or Less) Seriously, 95 YaLE 
each risks undermining the principle of judicial respect for the agency's expert judgment and programmatic responsibilities. We therefore expected that courts usually would acquiesce, perhaps grudgingly, in allowing agencies the last word.

These considerations led us to formulate another, more specific hypothesis about the interaction betwecn the nature of controls exercised by reviewing courts and the specific reasons for the remand. We supposed that agencies are inost likely to reaffirm their original decisions after rationale-based remands and are least likely to do so after law-based remands. In particular, the agency should be least constrained when the reviewing court does not reject what the agency has done, but simply demands a fuller explanation of, and justification for, that action. It should be most constrained when the court reverses the agency for having applied the wrong legal standard; in that event, application of the correct legal standard may well preclude the agency froin doing what it would like to do, regardless of which form of words and justificatious the agency uses to defend its result.

The data provide only weak support for our "agency gets the last word" hypothesis. Our most striking findings are that the agencies reaffirmed their original decisions in ouly $20-25 \%$ of the reinanded cases; Chevron did not really alter this percentage. However, in a substantially larger sliare of cases-about $40 \%$ of the reinands during the pre-Chevron period and about 37\% of those after Chevron - the post-reinand process actually produced what the lawyers agreed could be characterized as "major changes."147 (See Cliart 18.)

This "major changes" finding is especially impressive for two reasons. First, lawyers for both the petitioners and the agencies, wlio might have been expected to diverge greatly on this point, in fact came up with roughly similar estimates of the occurrence of "inajor changes." Second, the agencies were mucl more likely to adopt these clianges by relying upon the "old facts" (i.e., facts that were already in the pre-remand record) than by generating and relying upon "new" ones. ${ }^{148}$ This suggests that the mere occurrence of a reinand, witliout more, frequently causes an agency to alter its original position in important ways.

L.J. 62, 90-93 (1985). For the reasons stated in the text, we believed that such skepticism would be even inore warranted in the case of appellate review of agency action.

147. We made no effort to define what constituted "major" or "minor" changes, leaving such characterizations to the responding lawyers.

148. Agencies relied upon "old facts" in about one-third of the pre-Chevron remands and 54\% of the post-Chevron ones, a change for which we have no explanation. In contrast, they relied upon "new facts" in ouly about $20 \%$ of the pre-Chevron remands and about $17 \%$ of those after Chevron. 


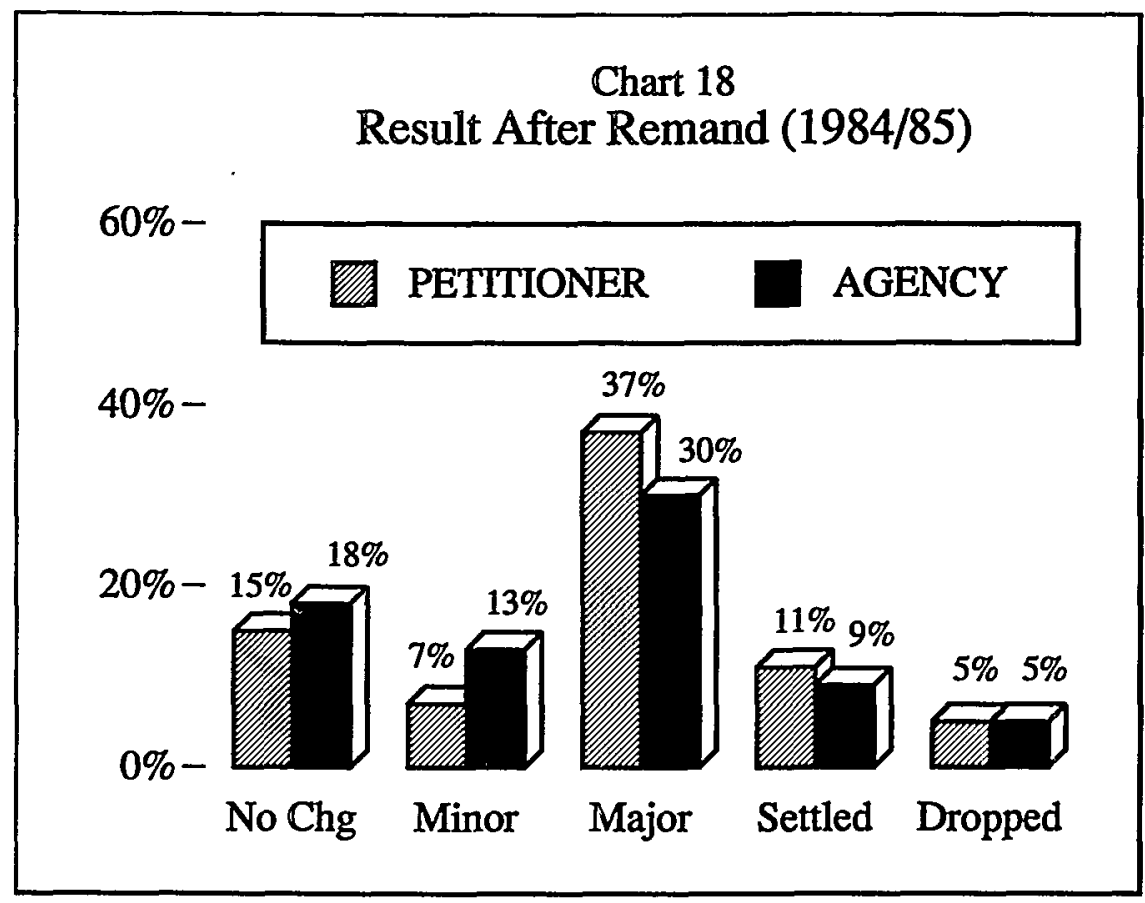

It -would be interesting to know why, and under what circuinstances, agencies change their original position after reinand. ${ }^{149}$ When we broke down the data by agency cluster, the only pattern that we found was that the health, safety, and environmental agencies and the INS were least likely to inake inajor changes after remand. ${ }^{150}$ The circuit-by-circuit breakdown failed to reveal any strong pattern: Agencies were less likely to inake inajor changes in cases reinanded from the D.C. Circuit than from other circuits generally, but the differences were not great.

More surprising was the fact that breaking down the data according to reinand type failed to provide any real support for our hypothesis, noted above, that agencies subjected to law-based remands would be the least likely simply to reaffirm. The agency's impetus to adopt changes apparently is fairly independent of the degree of freedom allowed to the

149. We would especially like to know when agencies make major changes simply on the basis of the old record, but at that level of data disaggregation our dataset is too small to present meaningful findings.

150. The health, safety, and environmental agency cluster made a major change in about $10 \%$ of its remands before Chevron and about $17 \%$ of them after Chevron; for the INS, the corresponding percentages were $17 \%$ and zero, respectively. The number of remands to these agencies, however, was relatively small. In contrast, some agency clusters experieneing more frequent remands made "major changes" in $25 \%$ or more of the cases. 
agency by the particular type of remand. At a minimum, this would seem to demonstrate that agencies are more open-minded than most commentators have believed. A more speculative proposition is that even when courts make rationale-based or fact-based remands-that is, remands that leave the agency most free to reaffirm its original position-they often commumicate doubts about the merits of the underlying agency pohicy, doubts that agencies apparently take seriously.

These inferences are strengthened further by the lawyers' responses to two other questions. Approximately $40 \%$ responded affirmatively to the query, "Did the court's remand affect the ultimate result reached by the agency?"151 Here again, we were struck not only by how large this response was but also by how closely the responses by the lawyers for botli agencies and opposing parties converged on this poimt. ${ }^{152}$ And when we asked the non-agency lawyers to describe "the practical effect on your client of the ultimate resolution by the agency after the court's remand," approximately $40 \%$ selected the response "much more favorable to chent,"153 while only about $17 \%$ selected the response "about the same effect on the chent as before remand." (See Chart 19.)

3. The Duration of Post-Remand Proceedings. We initially hypothesized that the elapsed time between the date of the remand and the date of the final agency action after remand would vary according to the type of administrative proceeding, the type of remand, and the type of agency. In particular, we expected that these proceedings would take longer in the following situations: in rulemaking proceedings (as opposed to adjudications); in proceedings involving fact-based remands (as opposed to remands involving law-based or rationale-based remands); and in health, safety, and environmental agencies (as opposed to other types of agencies). Our reasons for these expectations were discussed earlier. ${ }^{154}$

151. The $40 \%$ figure refers to the pre-Chevron period. It was even higher in the post-Chevron period- $41 \%$ according to the agency lawyers and $52 \%$ according to their opponents.

152. After Chevron, however, the lawyers' views diverged more. See supra note 151 for these figures.

153. The actual percentages were $39 \%$ pre-Chevron and $44 \%$ post-Chevron. We are not sure what to make of the fact that the percentage of the agency lawyers who responded "less favorable to chent" was far lower (2\% before Chevron, 9\% after) than the percentage of their opponents who responded "much more favorable to chent." We must concede that the response choices could have been more artfully phrased; for example "less favorable" is not quite the obverse of "much more favorable." Other possibilities are that agency lawyers manage to find silver linings even in defeat or that non-agency lawyers are more prone to exaggerate their hitigation success than are their opponents.

154. See supra Part III(C)(1). 


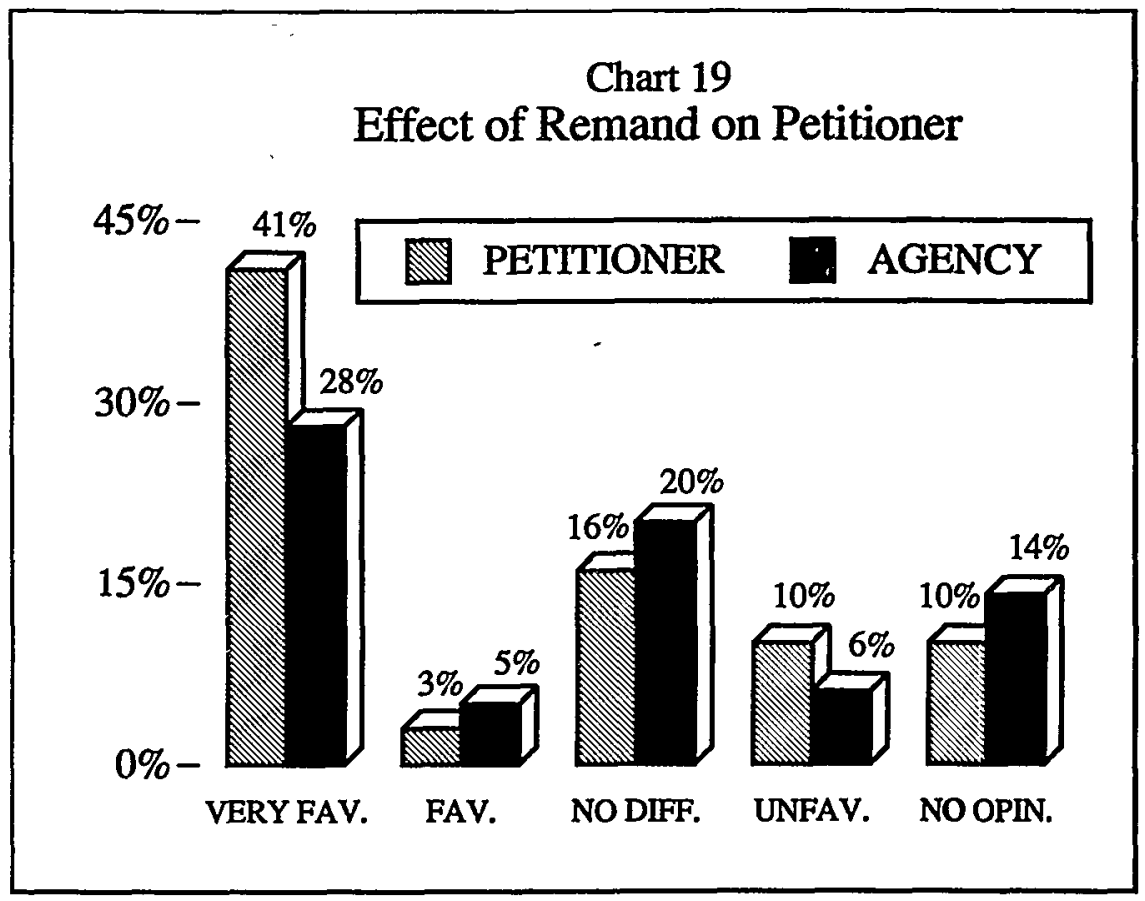

We obtained responses on the duration of the proceedings for 127 cases, or about $90 \%$ of the cases that were remanded in the 1984-85 period. ${ }^{155}$ The data reveal that the post-remand proceedings at the agency level alone took about seventeen months to complete on average. ${ }^{156} \mathrm{Al}$ most two-thirds of the remands were coinpleted within a year, but one im ten was still pending almost five years after the court reinanded to the agency. ${ }^{157}$

155. For some cases, neither lawyer provided information on the duration of the proceedings. For cases in which one of the lawyers provided it and the other did not, we used the information provided. For those in which both lawyers provided duration information but their numbers differed, we averaged them for purposes of this analysis.

156. These duration figures are quite conservative for two reasons. First, the datasets included 18 cases that were still pending when the lawyer interviews were conducted. In our duration analysis, we assumed that the cases from the 1984 dataset that were still pending were completed in 57 months and that the ones from the 1985 dataset were completed in 42 months. In fact, of course, these cases had not been "completed" at that point; for all we know, they still may be pending. Second, we measured elapsed time only from the date of remand. The duration of an administrative proceeding as a whole was, of course, inueh longer, for it also inust include (1) the time consumed between the imitiation of the proceeding and the date of the remand, and (2) the time consumed by any post-remand judicial review. Third, we ineasured elapsed time from the end of each of the datasets.

157. This figure refers to the 1984 remands. More than one in five (13 out of 60 ) of the 1985 remands was still pending three and a half years after the remand. 
The data on the duration of different types of proceedings seemed to contradict our hypothesis that rulemakings would take longer than adjudications. But because the total number of rulemakings in our dataset was small (only ten, or about $8 \%$ of the total during the entire 1984-85 period), and the standard deviations around all of the duration averages were large, we cannot say that the hypothesis has been refuted. Moreover, the differences in duration between the two proceeding types were generally small and the evidence pointed in different directions. ${ }^{158}$ Ratemakings took the longest time to complete (more than thirty months on average), but there were relatively few of them (six during the entire period).

When we analyzed the duration data according to the type of remand ordered by the court, we failed to confirm our hypothesis that factbased remands wonld take longer to complete than law-based or rationale-based ones. Law-based remands took the least time and rationalebased remands took the longest time. The differences, however, were small (generally less than two months) and the standard deviations were large.

Similarly, our analysis of the data broken down according to particnlar agency cluster failed to confirm our hypothesis that health, safety, and enviroumental agencies would take longer to complete. Indeed, the only pattern that we could discern was that the reinands to the INS took longest to complete, but even here the number of cases was too small to justify inuch confidence in this observation.

4. Significant Post-Remand Events. In administrative law, the adage "justice delayed is justice demed" has a special ineaning. It is not simply that the victim of agency illegality, in the absence of a stay, may continue to suffer while the agency's action remains in effect. The passage of time also affects the substance of administrative decisions more directly than it does decisions made in inost other legal contexts.

This difference reflects two distinctive features of administrative law. One is that the period of time elapsing between the original agency decision and the agency's post-remand response is often so protracted that new developinents-for example, changes in the applicable law, relevant facts, or the politieal environment-are almost bound to oceur. The other is that the norms of administrative law permit, and sometimes even require, those new developments to influence the inerits of the underlying

158. For the 1984 remands, rulemakings took more than 13 months, or two to three months longer than adjudications on average. For the 1985 remands, however, rulemakings averaged only about seven months, which was actually 10 months shorter than the average adjudication. We are unable to account for these disparities. 
agency decision in ways that would be inappropriate in a court decision. The value placed upon the agency's technical expertise, broad policy discretion, and political responsiveness mean that agencies are expected to take certain kinds of clianges into account in their policy decisions to a far greater extent than are courts. For example, the advent of a new President, changes in agency leadership, and other political factors are ordinarily deeined relevant to the merits. ${ }^{159}$ Similarly, the agency ordinarily must take into account changing economic conditions, statutory contexts, and court rulings. Far from seeking to insulate the agency froin these influences, administrative law recognizes their affirmative value in shaping the climate, and often the substance, of decisions.

These normative considerations led us to formulate several descriptive hypotheses about the kinds of events that occur after remand that may influence the agency's subsequent decision. We expected that any delay would increase the probability that intervening events would affect the outcoine of inany agency decisious. ${ }^{160}$ We thouglit that the inost important of these events would be changes in presidential or agency leadership, ${ }^{161}$ changes in the relevant law (other than that represented by the reinand itself), and changes in economic or competitive conditions gerinane to the agency's programmatic agenda. Less important, we supposed, would be changes in which lawyers landled a particular case.

The data reveal a high degree of agreement between the agency and opposing lawyers concerning the incidence of significant intervening events. Unfortunately, the wording of our question-"Were there any significant intervening events ... . which might help to explain any cliange?"- was inore ambiguous than it might lave been. We failed to inake clear that we were concerned ouly with reinands in which the agency altered its original deeision. This was ouly a subset (albeit a surprisingly large one, as we learned) of all reinanded cases. In what fol-

159. There are some limits on the right of agencies to take some of these factors into account, especially in adjudications. See, e.g., D.C. Fed'n of Civic Ass'ns v. Volpe, 459 F.2d 1231, 1247-49 (D.C. Cir. 1971) (setting aside agency approval of bridge because of political threats by member of Congress who supported bridge), cert denied, 405 U.S. 1030 (1972); see also Motor Vehicle Mfg. Ass'n v. State Farm Mut. Auto. Ins. Co., 463 U.S. 29, 41 (1983) (rule change inust not be arbitrary and inust be supported by record).

160. In thinking about the consequences of delay, it is important to distinguish three time-related factors that may affect outcomes: (1) the remand itself, because of low the reviewing court's words or implications may alter the parties' expectations for success; (2) the prospect of further procedings, because of the additional transaction costs they may entail; and (3) the influence of events that intervene between the agency's original decision and its final decision after the remand. The first two are discussed above, see supra Part III(C), "Remands and the Chevron Effect." Here, we are concerned only with the third.

161. Presidential changes, of course, often lead to changes in agency leadership. 
lows, then, we have assumed that our respondents so understood the question.

In almost one-third of the remands leading to changes (32\%), the lawyers responded either "no" or "don't know." This suggests that when agencies change their positions on remand, those changes often may have hittle to do with changes in the relevant personnel, politics, law, pohicy, or economic conditions. In those cases, other factors-including the appellate court's remand-rebuke to the agency-may better aecount for the agency's change of heart.

Given that the remands we studied occurred around the midpoint of a long presidential administration, we were not surprised to find that in fewer than $2 \%$ of the remands was the agency's change caused by a change of national administration or of agency heads. Perhaps for similar reasons, an even smaller percentage of the changes after remand were attributed to a change in the agency staff or lawyer handling the case. Changes in economic or competitive conditions were cited as the reason for the agency's new position in only about $2 \%$ of the remands.

The single most frequently cited reason for the agencies' post-remand changes was the occurrence of a significant change in the law (or in legislation, court decisions, or agency policy) other than the legal change contained in the remand itself. But the fact that this affected only $17 \%$ of the changed decisions on remand suggests that agencies that adopt new positions usually do so for rcasons having to do with factors internal to the agency itself, rather than for "environmental" reasons.

Our residual category of intervening events ("other") was also large. Fortunately, our interviewers often made notations on the coding sheets describing which "other" events the lawyers had in mind. These other events included the following: a different administrative law judge on remand; publicity about the case; the pendency of other cases; a compromise within the affected imdustry; a better rationale by the agency; agency policy change; changes in circumstances that facilitated settlement; publication of a congressional report; and a change in the agency's partisan composition.

We also expected that intervening changes in leadership, law, and economic conditions would be most influential in those types of proceedings and forums that we assumed would be most oriented to policy and political considerations: rulemakings, ratemakings, and D.C. Circuit cases generally. We conld not draw any strong inferences from our analysis according to proceeding type, because although roughly one-fourth of adjudications were said to be influenced by those kinds of changes, the nnmber of rulemakings and ratemakings in the sample was too small to permit a meaningful comparison. When we analyzed the data according 
to circuit, we did not find the relationship we expected; in fact, the results of D.C. Circuit remands were somewhat less likely to be influenced by such changes than the remands in the other circuits, but the differences were not great.

\section{Summary of Principal Findings}

This Article has presented a welter of data bearing on numerous hypotheses about administrative law. Lest the inost important and intriguing findings be obscured by the lengthy discussions, it may be useful to recapitulate them. We organize this summary of principal findings around the four broad objectives of the study, which in turn defined the four major sections of Part III. First, we hoped to produce some baseline information about parameters such as the character, magnitude, and consequences of judicial review of federal agency decisions. Second, by comparing this information at different points during a period spanning two decades (1965-85) in which the court-agency relationship is widely thought to have undergone a transfornation, we hoped to discern changes in these parameters over time. Third, we hoped to learn nore about remands, especially about what actually happens when the cases go back to the agencies where they originated. Finally, we hoped to gauge the effectiveness of the Supreme Court's highly controversial effort im Chevron to regulate the court-agency relationship through a change in legal doctrine.

Our analysis, we think, increases our understanding on each of these points. As we noted at the end of Part II, however, we regard our findings as more suggestive than conclusive. Some of these findings are incomplete and in some cases impressiomistic, as are soine of the data on which they are based. They cannot begin to capture the rich complexity and diversity of federal administrative law, nor do they purport to do so. In this regard, detailed case studies can provide far more textured accounts of court-agency relationships than our data permit. ${ }^{162}$ But such texture and detail coine at a price. Studies that are agency-specific can tell us hittle about the larger patterns traced on the political-legal landscape by federal agencies and courts. These larger patterns can be discerned only through the kind of panoramic and systemic, but inevitably

162. See, e.g., Galanter, Reading the Landscape of Disputes: What We Know and Don't Know (And Think We Know) About Our Allegedly Contentious and Litigious Society, 31 UCLA L. Rev, 4 (1983) (applying statistical analysis to determine the litigiousness of American society); Priest \& Klein, supra note 68 (applying statistical analysis to the decision of whether to settle or litigate); Whecler, Cartwright, Kagan \& Friedman, Do the "Haves" Come Out Ahead? Winning and Losing in State Supreme Courts, 1870-1970, 21 LAW \& Soc'y REv. 403 (1987) (applying statistical analysis to determine whether power and wealth influence court decisions). 
imprecise bird's-eye view attempted here. This view requires that a much richer database be amassed and a greater analytical effort mounted. ${ }^{163}$

\section{A. The Changing Style of Appellate Opinions}

Our first finding, based on data published by the Administrative Office of the U.S. Courts (AO), is well known: The administrative law caseload in the circuit courts has increased rapidly and, at least as measured by what the AO calls "termination on the merits" (as distinguished froin filings), fairly steadily. Less well known (but also based on that published data) is that this larger caseload constitutes a rather small and steadily shrinking portion of the circuit courts' dockets-only $7 \%$ in 1987.

A striking finding that may have wide-spread implications for administrative law concerns the phenomenon of "table decisions"- summary decisions for which no reasoning or factual description is published. Today, the majority of administrative law cases are disposed of in this way. In 1985, almost $60 \%$ of all dispositions were by these "table decisions," compared to $38 \%$ in 1975 , and an unknown number in 1965. ${ }^{164}$ (See Table 1).

This phenomenon has received relatively little attention or sustained analysis by academic commentators, and its significance for administrative law is not yet clear. It is tempting to speculate on how the predominance of table decisions has affected the affirmance rate, yet even the direction of causality remains uncertain. As we have seen, and as one might expect, all but a handful (albeit a surprisingly large handful) of these table decisions are affirmances. The dramatically incrcased use of table dispositions may reflect an increase in affirmances caused by other factors; in this view, table decisions are simply a less time-consuming way to clear judicial dockets than writing full published opimions. On the other hand, the increased use of table decisions may be a cause of a higher affirmance rate, rather than (or as well as) an effect. In this view, docket considerations motivate reviewing courts to dispose of cases summarily, and summary dispositions can be accomplished most readily through affirmance by table decision rather than reversal, remand, or affirmance by written opimion. Unfortunately, our data do not permit us to

163. The data compiled by the Administrative Office of the United States Courts is useful but is only a starting point for analysis. An earlier recommendation by the Administrative Conference urged that the gathering and reporting of such data be improved. ACUS Recommendation No. 696, Compilation of Statistics on Administrative Procedings by Federal Departments and Agencies, 1 C.F.R. § 305.69-6 (1988).

164. See supra Part III(A)(1). 
determine which of these views is correct, although the significant number of table decisions that do not affirm tends to undercut the latter view.

The potential importance of table decisions, however, goes well beyond its positive association with the affirmance rate. This method of promulgating decisions raises fundamental questions of the legitimacy and public perception of legal process. When courts dispose of a large number of agency cases summarily and without opimon, administrative law is deprived of the benefits of reasoned justification. In that event, it loses the salutary imtellectual discipline and normative significance that opimion writing imposes, and its processes and outcomes appear arbitrary. If courts decide significantly more cases without having to justify their decisions, administrative law becomes increasingly opaque and imcoherent. On the other hand, routine cases should be handled routinely and busy courts should not have to expend scarce time and effort belaboring the obvious and familiar. Because the shift toward table decisions as the predominant form of resolution has oceurred swiftly and without adequate reflection, it is by no mcans clear that the current practice strikes the optimal balance between these competing considerations. This phenomenon clearly warrants further imvestigation.

Our findings concerning opimion length and footnoting are of lesser importance, of course, but a few of them nevertheless are of some interest for what they may reveal about the emerging style of administrative law opimion-writing and the effect of docket pressures. ${ }^{165}$ In general, opinious written in the mid-1980s were much shorter on average than those written a decade earher, although this effect is almost entirely due to the courts' mcreased use of table decisions. The D.C. Circuit writes longer and more heavily footnoted opimions than the other circuits; im this respect it is even more of an outher than it was im 1975.

Of greater significance, perhaps, is our finding that consensus within circuit courts, as measured by the proportion of one-opimion cases, increased in all circuits betwecn 1965 and 1975, and remained unchanged a decade later, even when table decisions are excluded. ${ }^{166}$ Including them, of course, would dramatically strengthen this consensus imdex. Even more impressive is the maintenance of this level of consensus at a point (1984-85) well into an administration that was determined to appoint federal judges of a different ideological stripe. Again, the D.C. Circuit was an outher; in all periods its consensus level was lower than that im the other circuits. Yet even the D.C. Circuit's consensus level appeared

165. See supra Part III(A)(2).

166. See supra Part III(A)(3). 
to increase between 1975 and 1984-85, although more recent appointments to that court may well have reduced that consensus.

\section{B. The Ages of Administrative Law}

The most important finding that emerges from our twenty-year punctuated longitudinal analysis is that the circuit courts are affirming agency decisions at a steadily mcreasing rate, a rate that approximated $76 \%$ in 1984-85, and reached over $81 \%$ in 1985 -just after Chevron. ${ }^{167}$ When we measure the petitioners' probability of success-combining the reversals and the $40 \%$ of the remands in which the lawyers report a "major change" in the agency's position on remand-we find that it was about $12 \%$ in 1985, a figure that our 1988 data suggest may have increased slightly as Chevron's effeet weakened. A success rate of only $12 \%$ raises an important question as to why petitioners appeal as frequently as they do. In Part III, we speculated that with respect to some but not all agencies, the explanation may be found partly in the possibilities for using appeals to delay the effect of agency action. ${ }^{168}$ This question clearly warrants further researcli.

Our findings concerning the growth of rulemaking were somewhat surprising. ${ }^{169}$ Although ruleinaking's share of the administrative law caseload increased twenty-fold between 1965 and 1984-85, it still constituted only $6.5 \%$ in the latter period. Even more striking is the fact that when we excluded from our analysis agencies that apparently never used rulemaking, and examined only those that sometimes use it, rulemaking's share was still only $9.4 \%$ in $1984-85$, a share that was actually lower than it had been in 1975. We speeulated in Part III that reviewing courts' imposition of adjudicatory-type procedural and evidentiary burdens on rulemaking during this period may have had the perverse effect of discouraging its use.

This information relates to our finding concerning the agency composition of the administrative law caseload, which has changed dramatically since 1965.170 A docket once doininated by labor and patent cases is now dominated by labor, personnel, and immigration cases-virtually all of which are adjudications. Agencies that engage in "social regulation" accounted for less than $4 \%$ of the caseload in 1984-85. When we examined the circuit court composition of the caseload, we found that the D.C. Circuit's share of the national administrative law docket reinained remarkably stable over the twenty-year period, comprising about

167. See supra Part III(B)(1).

168. See supra text accompanying notes 68-72.

169. See supra Part III(B)(2).

170. See supra Part III(B)(3). 
$12 \%$ in 1984-85.171 The Federal Circuit's share (36\%) was the largest, distantly followed by the Ninth Circuit (15\%). Another striking finding was the steady decline in, and the rarity of, en banc decisions, especially outside the Federal Circuit. ${ }^{172}$ Even including the Federal Circuit, fewer than $2 \%$ of the non-table cases were heard en banc in 1984-85.

\section{Remands and the Chevron Effect}

If our data on dispositions and the use of table decisions indicate a growing tendency of reviewing courts to defer to agencies, our data on remands also suggest that the Supreme Court's Chevron decision has reinforced that deference, pushing the overall affirmance rate to levels higher than those that prevailed in 1965, 1975, and 1984-just before Chevron was decided. ${ }^{173}$ Affirmances imcreased by almost $15 \%$ after Chevron, and both remands and reversals declined by roughly $40 \%$. The post-Chevron affirmance rates, we found, were bimodally distributed; one group of agencies clustered around $80 \%$, while another group clustered around $60 \%$. We suggested that the different subject matters upon which these two groups of agencies focus-a difference that results in the first group's reliance on adjudication while the other group sometimes uses rulemaking -might help explain this distribution.

When we refined our analysis of remands in order to appraise Chevron's effect more precisely, four findings of interest emerged.174 First, inore of the increased affirmances after Chevron "came from" reduced reversals than from reduced remands. This "outcome displacement" effect was fully consistent with the purpose of Chevron, which was to make it harder for reviewing courts to reverse for agency errors of law. Second, Chevron was immediately followed by a large decline im substantive law remands - the kind that Chevron aimed to discourage-while the total number of remands remained constant. Although these data would seem to establish that Chevron also had a pronounced "reasons displacement" effect, they actually are inore equivocal than that. Third, the increase in affirmance rates after Chevron had eroded by 1988; the affirmance rate in 1988 had shipped to $75.5 \%$, roughly halfway between the pre- and post-Chevron rates. Fourth, the remand rate increased significantly between 1985 and 1988, although fewer of the increased remands "came from" reversals than Chevron's logic had led us to expect.

These findings suggest that Chevron affected outcomes differentially and that those outcome effects differed over time. The expected affirm-

171. See supra Part IM(B)(4).

172. See supra Part III(B)(5).

173. See supra Part III(C)(1).

174. See supra Part III(C)(2). 
ance-increasing effect occurred immediately but had weakened by 1988 , whereas the expected remand-increasing effect did not occur immediately but was evident in 1988.175 These findings are consistent with the notions that Chevron achieved its intended goal in the short run, and that post-Chevron developments-including the Supreme Court's own weakening of Chevron in subsequent cases and the lower courts' strategic responses to these decisions-frustrated those purposes as time passed.

When we disaggregated the data on the effects of Chevron by examining particular circuits and agencies, two other striking findings emerged. ${ }^{176}$ First, we found that the D.C. Circuit, whose affirmance rates had been lower than those of the other circuits throughout the twenty-year period and were far lower by the time Chevron was decided, responded to Chevron by affirming even less often than before, in sharp contrast to the other circuits, which responded to the decision by increasing their already high affirmance rates. And, second, the "outcome displacement" effect of Chevron turned out to vary considerably among the agency groups; the affirmance rate actually declined for the immigration agency and the "other regulatory" group.

Taken as a whole, our findings with respect to the effects of Chevron on remands, although not unequivocal, support a general conclusion of some significance to the analysis of legal process in administrative law. On the evidence of this study, the Supreme Court is sometimes able to effectively shape the court-agency relationship through the kind of relatively broad, open-textured rule adopted in Chevron. For reasons that we explained earher, ${ }^{177}$ and because of the quite different conclusion drawn by some commentators following the Court's Vermont Yankee decision, ${ }^{178}$ this finding was unexpeeted.

\section{What Happens After Remand?}

Our data concerning the response of agencies to judicial remands yield one especially imteresting finding. Our prediction that agencies would manage to find ways to reaffirm their original decisions-what we called "the agency gets the last word" hypothesis-was not borne out. ${ }^{179}$ In approximately $40 \%$ of the remands, the agencies adopted "inajor changes," and inost agencies appeared to do so primarily because of the remand (i.e., on the basis of the old administrative record).

175. See supra Part III(C)(3).

176. See supra Part III(C)(4)\&(5).

177. See supra text accompanying notes 113-20.

178. See Scalia, supra note 114.

179. See supra Part III(D)(2). 
This $40 \%$ figure is much higher than we expected. But it does, of course, mean that $60 \%$ of the remands did not result in any "major changes." This means that petitioners succeeded in obtaining a major change in the agency's position in only about $12 \%$ of the cases-the $8 \%$ in which the circuit court reversed the agency outright, plus $40 \%$ of the $9 \%$ of the cases in which the court remanded, and the agency on remand adopted a major change.

\section{Conclusion}

We beheve that this Article demonstrates anew the value of using large-scale statistical studies of cases, ${ }^{180}$ here augmented by interviews with lawyers, to subject important propositions about law and legal change to empirical testing. Although we have deployed this technique in the field of administrative law, its applicability extends as broadly as the phenomenon of adjudication itself.

The traditional method of studying changes in the law-the "leading cases" approach developed by Christopher Columbus Langdell in the 19th century and still used today-is quite unsatisfactory. It posits that the "law" (defined by Ohiver Wendell Holmes, Jr. as "what the courts will do in fact"181) can be captured in a few supposedly exemplary cases. These cases-cases that are generally selected by academic writers using unconscious, or at least unstated, principles of selection-are in turn assumed to state principles of legal doctrine that explain the results in a much larger number of disputes. As our colleague George Priest has observed, however, this approach to doctrinal analysis has not proved very useful in making predictions about law; better methods are needed. ${ }^{182}$ We think that our study confirms Priest's skepticism about the value of forming opmions about trends in the law based on statements in a few leading cases and articles.

Our own methodology, of course, is far from perfect. The conclusions to be drawn can be no better than the data on which they are based, and the data relating to some of the most interesting characteristics of decided cases are impressionistic and subject to competing interpreta-

180. See, e.g., J. MASHaw, BUREaUCRatic JUSTICE (1983) (Social Security Administration); J. MASHAw \& D. HARFsT, The StrugGle For AUTo SAFETY (1990) (National Highway Traffic Safety Administration); R. MELNICK, supra note 1 (Environmental Protection Agency); see also D. Rosenbloom, The Federal Labor Relations Authority (1988) (unpublished manuscript) (available from authors). With the support of the Administrative Conference of the Umited States, Peter Schuck and Theodore Wang are drawing upon the data and methodology of this study and undertaking a collaborative study of the relationship between a particular agency-the Immigration and Naturalization Scrvice-and the reviewing courts.

181. Holmes, The Path of the Law, 10 HaRv. L. Rev. 457, 461 (1897).

182. Priest, Selective Characteristics of Litigation, 9 J. LEGAL STUD. 399, 399-401 (1980). 
tions. Even apart from these problems, our analysis failed at certain points to accomplish what we had hoped. ${ }^{183}$

Still, this approach seems far more promising than the traditional alternative, especially in the area of administrative law. The state of knowledge about what agencies and reviewing courts actually do in most cases, and about how Supreme Court directives influence their behavior, is so primitive that studies of this kind are likely to produce valuable information regardless of what their data show. If it had turned out, for example, that the Chevron decision did not influence reviewing courts, that would have been just as revealing and interesting a finding as our actual results. As it happens, we are reassured to learn from our study that the Supreme Court's law does indeed matter to reviewing courts, and that their law, in turn, matters to agencies.

183. Some of the comparisons that we thought would prove interesting did not bear fruit-either because our database was too small to permit multiple comparisons (e.g., NLRB cases decided by the First Circuit vs. NLRB cases decided by the Second Circuit), or because the factors that we isolated for study turned out not to have as much predictive power as we imagined before we did the study. Thus, for example, our hypothesis that the legal grounds on which courts remanded cases to agencies might be a powerful factor influeucing the agency's ultimate decision after remand turned out to have been incorrect: We did not observe significant differences between the final results reached when, for instance, courts remand on a procedural ground than when they remand for further explanation. 


\section{APPENDIX A-AGENCIES AND AgENCY GROUPINGS}

A. National Labor Relations Board

NLRB National Labor Relations Board

B. Health and Environment

AEC/NRC Atomic Energy Commission/Nuclear

Regulatory Commission

EPA Environmental Protection Agency

FDA Food and Drug Administration

FMSHRC Federal Mine Safety and Health Review

Commission

OSHRC Occupational Safety and Health Review

Commission

C. Other Regulatory Agencies

CAB Civil Aeronautics Board

CFTC Commodity Futures Trading Commission

FCC Federal Commnmications Commission

FEC Federal Elections Commission

FMC Federal Maritime Commission

FPC/FERC Federal Power Commission/Federal Energy

Regulatory Commission

FTC Federal Trade Commission

ICC Interstate Commerce Commission

SEC Securities and Exchange Commission

D. Immigration

INS Immigration and Naturalization Service

INS/BIA INS/Bureau of Immigration Appeals

E. Civil Service

$\begin{array}{ll}\text { CSC } & \text { Civil Service Commission } \\ \text { MSPB } & \text { Merit Systems Protection Board } \\ \text { MSPB } & \text { Merit Systems Protection Board }\end{array}$

F. Department of Labor

DOL Department of Labor

G. Other Departments

DHHS Department of Health and Hnman Services

* refers to the employing agency 
DHUD Department of Housing and Urban-

Development

DOC Department of Commerce

DOD Department of Defense

DOE Department of Energy

DOED Department of Education

DOI Department of the Interior

DOJ Department of Justice

DOT Department of Transportation

DTRE Department of Treasury

USDA Department of Agriculture

H. Patent and Trademark

PAT Patent and Trademark Office ${ }^{184}$

I. Other Administrative Agencies

ACTION

BCA

CIR Commissioner of Internal Revenue

CRT Copyright Royalty Tribunal

FDIC Federal Deposit Insurance Corporation

FHLBB Federal Home Loan Bank Board

FLRA Federal Labor Relations Authority

FRB Federal Reserve Board

GAO General Accounting Office

GSA General Services Administration

INDCC Indian Claims Commission

IRS Internal Revenue Service

ITC International Trade Commission

OPM Office of Persounel Manageinent

RRRB Railroad Retireinent Board

SSA Social Security Administration

USPS U.S. Postal Service

VA Veterans Administration

WMATC Washington Metropohtan Authority Transit

Commission

184. By accident, this office was assigned the acronym "PAT" instead of the conventional acronym, "PTO." 


\section{APPENDIX B-CODING SHEET}

Researcher:

B. Citation: F2d

F. Number of opinions

H. First Petitioner

I. Agency

J. Circuit

K. (circle)

1. 3-judge

3. Table (shepardize)
A. Case number

C. D. Last Page

G. Number of footnotes (all opinions)

\section{Date $\frac{}{\text { (mo) }}-\frac{}{\text { (day) }}-\frac{}{\text { (year) }}$}

2. en banc

4. 4 or more, not en banc [last decision, e.g. reh. den.]

M. Agency proceeding type (circle)

1. Adjudication

2. Rulemaking

3. Ratemaking

4. Other Describe:

5. No mdication or Table Case

N. Result code (circle all that apply) - Reviewing court:
1. Affirmed in toto
2. Affirmed in part

Reversed:
3. No jurisdiction
4. Other

* Reinanded - law-based
5. Procedure
6. Substance

(supporting page)

* 7. Remanded - fact-based (supporting page)

* 8. Remanded - rationale-based (supporting page)

9. Other (e.g. retained on docket)

10. Reinanded - no indication of reason

11. Reversed - no indication of reason

Describe (reinands \& other):

AA. Standard of Review (circle all that apply)

1. De novo

3. Substantial evidence

5. Abuse of discretion

6. Other (Describe):

7. No indication.
2. Error of law

4. Capricious and arbitrary

* (remands only) Petitioner's counsel (firm) (city)

* (remands only) Agency counsel 
Interview with Petitioner

(case number)

Date(s) of interview

Petitioner's counsel (name)

(firm)

(city)

O. Procedures after remand:

(phone)

1. No further proceedings after remand.

Agency issued new opinion that:

2. Supplied additional explanations but no cliange in legal theory or interpretation.

3. Adopted new legal theory or interpretation.

4. Agency supplemented record (additional evidence), but did not hold new hearings.

5. Agency held additional hearings (oral or written).

6. Other (Describe):

P. Result after remand (circle all that apply) - Agency:

1. Re-affirmed earher decision (no change in result).

2. Minor clianges (Describe):

3. Major clianges (Describe):

4. Agrced to settlement.

5. Adopted new legal theory.

6. Agency relied on old facts (in record at time of reinand).

7. Agency relied on new facts (not in record at remand).

8. Agency issued new notice of proposed rulemaking (NPRM).

9. Agency dropped the proceeding.

10. Other (Describe):

Subsequent proceedings citation(s)

(please send copy if unpublished)

Q. "Which of the following would you say best describes the practical effect on your client of the ultimate resolution by the agency after the eourt's remand?" (circle one):

1. Much inore favorable to client.

2. Only slightly inore favorable to client.

3. About the same effect on client as before remand.

4. Less favorable to client.

5. No opinion, or won't say.

R. "In your opinion, did the court's remand affect the ultimate result reached by the agency?"

1. Yes (Describe how):

2. No.

3. No opimion, or won't say. 
S. "Were there any other significant intervening events between the agency's original decision and its final decision which might help to explain any changes?"

0 . No, or don't know.

1. Change of national administration.

2. Change of agency head.

3. Change of agency staff or lawyer handling case.

4. Significant change of law (other than reinand itself):

a. New legislation or amendment.

b. Other court decisions

c. Change of agency policy

5. Change in economic or competitive conditions.

6. Other (Describe):

T. Time elapsed between remand and final agency action (in inonths):

Others to contact:

Name

Phone

Role

Interview with Agency

(case number)

Date(s) of interview

Agency counsel (naine)

(firm)

(city)

U. Procedures after remand:

1. No further proceedings after remand.

Agency issued new opimion that:

2. Supphed additional explanations but no change in legal theory or interpretation.

3. Adopted new legal theory or interpretation.

4. Agency supplemented record (additional evidence), but did not hold new hearings.

5. Agency held additional hearings (oral or written).

6. Other (Describe):

V. Result after remand (circle all that apply) - Agency:

1. Re-affirmed earlier decision (no change in result).

2. Minor changes (Describe):

3. Major changes (Describe):

4. Agreed to settlement. 
5. Adopted new legal theory.

6. Agency relied on old facts (in record at time of remand).

7. Agency relied on new facts (not in record at remand).

8. Agency issued new notice of proposed rulemaking (NPRM).

9. Agency dropped the proceeding.

10. Other (Describe):

Subsequent proceedings citation(s)

(please send copy if unpublished)

W. "Which of the following would you say best describes the practical effect on the petitioner (i.e. the regulated party that sought judicial review) of the ultimate resolution by the agency after the court's remand?" (circle one):

1. Much more favorable to petitioner.

2. Only slightly more favorable to petitioner.

3. About the same effect on petitioner as before remand.

4. Less favorable to petitioner.

5. No opinion, or won't say.

$\mathrm{X}$. "In your opinion, did the court's remand affect the ultimate result reached by the agency?"

1. Yes (Describe how):

2. No.

3. No opinion, or won't say.

$Y$. 'Were there any other significant intervening events between the agency's original decision and its final decision which inight help to explaim any changes?"

0 . No, or don't know.

1. Change of national administration.

2. Change of agency head.

3. Change of agency staff or lawyer handling case.

4. Significant change of law (other than remand itself):

a. New legislation or amendment.

b. Other court decisions.

c. Change of agency policy.

5. Change in econounic or competitive conditions.

6. Other (Describe):

Z. Tinie elapsed between remand and final agency action (in months):

Others to contact:

Name

Phone

Role 


\section{APPENDIX C-USE OF WESTLAW IN EMPIRICAL RESEARCH}

\section{A. Use of Electronic Sources for Empirical Legal Research}

As in all einpirical research, there is the possibility of error in the data collection process of a project this large. To minimize this risk, we utilized WESTLAW computer search techniques to screen West's collection of federal appellate decisions to identify the set of cases that our research assistants should have included in their data collection. We decided to attempt the search rather late in the study's process, after the research assistants had completed the hammer-and-tongs screening of thousands of cases in the volumes of the Federal Reporter. Our hope, of course, was that the WESTLAW search would generate the identical or nearly identical set of cases as the research assistants.

Because we had used so many research assistants over the course of the study's almost three-year duration, using another source to check the data gathered was a valuable means of enhancing consistency among the results of the data collection. We were indeed grateful for being able to use the technique; checking the results of the WESTLAW search agamst the database identified several "holes" in the databases that we filled before completing the analyses. One very important instance of this was our discovery that the cases in one volume of the Federal Reporter had not been catalogued at all, suggesting either that there was some misunderstanding by at least one research assistant about his or her assignment or that there was a problein with our data entry process. Although the total number of other data collection errors was probably not siguificant in terms of the statistical results of the study, the error-checking process was, nonetheless, a valuable ineans of ensuring that the data we received from the research assistants was consistent with what we expected them to gather.

\section{B. The Search Procedure of Our Study}

The purpose of the search was to scan the WESTLAW federal appellate court files to locate the cases that belong in our 1965 and 1975 datasets. The criteria for locating "included" cases were that each case: (i) had to be an appcal from an administrative agency; (ii) had to be within the appropriate time period; (iii) must not have been a tax-related decision; and (iv) must not have been an appeal from a district court. The searches are reprodueed below, following the general descriptions.

Narrowing the searches by date was fairly straightforward; WESTLAW needs ouly the beginning and ending dates. We then narrowed the search by topic by examining the WESTLAW "Topic List," flagging all topics related to administrative law, and then including them 
in the general search. The topics we chose appear in the searches below. Then, to minimize the possibility of missing solne entries by not selecting all of the appropriate topics, we added a search of the syllabus of each case for the word "administrative" (as in "appeal froln administrative order") or "petition" (as in "petition froln [x] agency" or "petition for review"). Finally, to eliminate the possibility of including tax-related or district court cases, we eliminated entries for which the syllabus contained "tax**," "taxation," "taxable" or "district."185

The search for 1975 was:

DA(AFT 1-1-65 \& BEF 7-1-65) \& (TOPIC (15A 2477 83H 92H 99114 148A 190199 232A 243258450283291300304306310 313A 317 317A 320339 349B 356A $372382383 \quad 404 \quad 405411412413 \quad 414$ ) SY(ADMINISTRATIVE PETITION)) \% SY(TAX** TAXATION TAXABLE DISTRICT).

And for 1965:

DA(AFT 1-1-65 \& BEF 7-1-65) \& (TOPIC (15A 2477 83H 92H 99114 148A 190199 232A 243258450283291300304306310 313A 317 317A 320339 349B 356A $372382 \quad 383404 \quad 405411 \quad 412413 \quad 414$ ) SY(ADMINISTRATIVE PETITION)) \% SY(TAX** TAXATION TAXABLE DISTRICT). ${ }^{186}$

After conducting the WESTLAW search, one of our research assistants matched the entries in our databases against the lists generated by WESTLAW. He flagged those cases appearing on the WESTLAW search but not in our database, and he then checked the new cases identified by WESTLAW to see if we should include thein. He also checked those cases appearing in our databases which WESTLAW did not pick up. This "double check" process led us to include a few additional cases in the databases and to correct or delete soine cases that were already entered before conducting the final round of statistical analyses.

185. The district court screen may seem crude but is actually highly accurate. The syllabus of every case that is an appeal from a district court contains the phrase "appeal from the district court of - " and the word "district" is used very rarely for other purposes. While checking the results of the search against our database, we discovered a few cases in our database that WESTLAW eliminated by virtue of the search procedure's elimination of cases based on other constructions of "district" (e.g., "water district"), but the number was very small. If we were to run another search with the same goal of eliminating appeals from district courts, we would screen by "district court" instead of by "district" ouly.

186. In WESTLAW-ese, "or" is impled when there is no connector between entries. Therefore, SY(ADMINISTRATIVE PETITION) translates to "the word ADMINISTRATIVE or the word PETITION appears in the syllabus" (of course, both may appear). Further syntax includes: \% means "but not"; "*" is a umiversal ("wildcard") character which permits any number of characters to appear in its location. 


\section{APPENDIX D-DATA ON THE LENGTH AND FoOTNOTING OF OPINIONS}

The data generally bear out our expectation that the D.C. Circuit would write longer, more heavily footnoted opinions than the other circuits. Perhaps more interesting, however, is the fact that the disparity did not appear until the 1975 period, after which it increased significantly over time. During the 1965 period, the D.C. Circuit's average length (5.9 pages) was actually less than the average among all circuits (6.5 pages). But ten years later, this pattern had changed. Excluding table decisions, ${ }^{187}$ the D.C. Circuit's opinions ten years later had almost doubled in length (to 11 pages) and were more than $40 \%$ longer than the all-circuits average of 7.7 pages. (The Second Circuit's opinions were longer still, averaging 12.2 pages.) By the 1985 period, the D.C. Circuit's opinions had not only grown another $12 \%$ longer (to 12.4 pages) but were considerably longer than those of any other circuit and more than $60 \%$ above the all-circuits average. ${ }^{188}$

One might seek to explaim the steady lengthening of the D.C. Circuit's opinions as siniply reflecting a more general tendency toward greater judicial prolixity. The data, however, suggest otherwise. In fact, the all-circuits average opinion length was about the same in 1985 as it was in 1975 ( 7.7 pages). If table decisions were included in the analysis, the average opinion length would actually be much lower in 1985 than $m$ 1975. ${ }^{189}$

As striking as the growing length of D.C. Circuit opinions is the fact that the disparity between it and the other circuits in this respect is also increasing. Two plausible explanations for this growing disparity occur to us. First, it might reflect the facts (if these propositions are true) that the D.C. Circuit's docket of administrative law cases is not only heavier but is more coinplex than that in other circuits and that its coinplexity relative to that in other circuits has also increased. Second, factors related to the particular membership of the D.C. Circuit might account not only

187. For analytical purposes, it is important to do so because we coded each table decision as being one page in length. In addition, of course, they contain no footnotes and no separate opinions. As table decisions becane a more significant part of the study sample, therefore, they increasingly distort the data on those variables.

188. See also Eisenberg \& Schwab, What Shapes Perceptions of the Federal Court Systems?, 56 U. CHI. L. REv 501, 505-06 (1989), for the proposition that the D.C. Circuit's opinions are twice as long, and contain six times as many footnotes, as other circuits. The D.C. Circuit's average in the most recent period was probably disproportionately affected by one or a few long opinions, as rcflected by a large standard deviation (10.3).

189. The opinions in the Federal Circuit, which did not exist in 1975 but which accounted for $17 \%$ of the cases in our 1985 dataset (only the D.C. Circuit, with over 21\%, accounted for more), were among the shortest, averaging 5.6 pages. 
for the longer opinions but also for the greater inter-circuit disparity over time. Although several such factors might have been operating, the most plausible one is the degree of divisiveness on that court relative to others and over time. Our data permit us to shed soine hight on that variable, and we discuss it below in section (C) relating to the fragmentation of the circuit courts' decisions.

We also had hypothesized that regardless of the circuit, the length of appellate court opinions and the amount of footnoting in agency cases would vary depending upon certain features of the judicial review setting. Four features were of particular interest: (1) the type of agency proceeding being subjected to judicial review; (2) the nature of the reviewing court's disposition of the case, especially in remands; (3) the coinpositional structure of the reviewing court; and (4) the type of agency under review.

\section{A. Agency Proceeding Type}

We expected that the length and footnoting of opinions would be greater in ratemaking and rulemaking proceedings than in adjudications. ${ }^{190}$ This expectation was based upon the behef that ratemakings and rulemakings, relative to adjudications, tended to involve inore techmical legal and policy issues, longer records, a larger and more diverse group of parties, and broader apphicability and precedential significance. These features, we thought, would induce courts to write more elaborate, heavily documented, and reversal-proof opinions.

The best data for testing our hypothesis were in the 1975 sample, ${ }^{191}$ and they strongly confirmed it. The average opinion length in rulemakings was 15.4 pages, more than twice the length of adjudication opinions. Ratemaking opinions were also longer than adjudications, averaging 9.9 pages. The anticipated pattern was further confirmed by the data on the

190. We had, of course, expected our data to confirm the post- 1965 move by many agencies from an almost exclusive preoccupation with adjudication to a greater use of rulemaking; see $S$. BREYER \& R. STEWART, supra note 35, at 473 . Still, the magnitude and swiftness of that sea change surprised even us. While more than $92 \%$ of the cases in our 1965 sample were adjudications and less than $2 \%$ were rulemakings or ratemakings, the proportion of adjudications only 10 years later had declined to just over $50 \%$, and the rulemakings and ratemakings accounted for almost $10 \%$. By 1984-85, adjudications constituted only $33 \%$, but by this time (unlike in 1975) the data on agency proceeding type were confounded by the large number of table cases in the sample, thus significantly reducing the percentage of the total that were adjudications.

191. The reason is that the number of rulemakings (and to a lesser extent, ratemakings) was too low in 1965 to support any conclusions, while in 198485 the number of table decisions was so large as to distort the data on average opinion length. 
footnoting of opinions, which we took to be a very rough proxy for the degree of documentation of evidence. 192

\section{B. Nature of Court's Disposition}

We expected law-based remands ${ }^{193}$ to be longer and more heavily footnoted than any other type of remand. This hypothesis reflected our behef, similar to our view (now confirmed) concerning the agency proceeding type variable, that courts would devote greater care to those opinions in the belief that law-based remands would usually have broader applicability and precedential significance than fact-based or rationalebased remands. 194

The data refuted this hypothesis. During the 20-year period of the stndy, law-based remand opinions were usually, although not invariably, shorter and less heavily footnoted than either fact-based or rationalebased remands. ${ }^{195}$ Whatever the factors influencing opinion length and footnoting inay be, remand type does not appear to be one of thein.

\section{Compositional Structure of Reviewing Court}

We had also expected that three-judge panels would tend to write shorter and less heavily footnoted opinions than larger panels or the entire court en banc. This expeetation was based upon our two assumptions, mentioned earlier, that cases selected for en banc decision are generally more coinplex and controversial than the others; and that quite independent of the complexity of the case, greater diversity and disagreement will be generated as the number of decisionmakers is increased. We speeulated that im order to produce a majority in these circumstances, the opinion writer must engage in more elaborate justification, more numerous distinctions of a doctrinal or factnal kind, and more conspicuous efforts at supporting the decision with the kinds of references that lend themselves to footnoting. We expected that these iniperatives would be reflected in longer opinions and more extensive footnoting.

192. Rulemakings and ratemakings averaged 24.4 and 37 footnotes, respectively, while adjudications averaged 11.8 .

193. See supra text accompanying notes 123-26.

194. Our colieague, Professor Ruth Wedgwood, had the opposite expectation. She believed that law-based remands would use fewer footnotes because as a matter of form and convenience, legal authorities can be, and often are, cited in text. Conversation with Ruth Wedgrood in New Haven, Connecticut (Feb. 8, 1990).

195. During the most recent period (1984-85), law-based remands had opinion lengths averaging seven (for procedure-based ones) and eight pages (for substantive-based ones), compared to an average of 10 and 11 pages for fact- and rationale-based ones. Law-based remands averaged six and eight footnotes respectively, compared to 11 footnotes for fact- and rationale-based ones. 
Before discussing the data relating opinion length and footnoting to court composition, we should underscore one important finding: The use of en banc decisions has declined dramatically. Indeed, the number of en banc decisions in our samples for the 1975 and $1984-85$ periods is so sinall (12 in each period) that our opinion length and footnote averages are probably not very meaningful in absolute terms.

In any event, no consistent pattern emerges when we analyze the non-table decisions for these variables. In 1965, when the number of en banc decisions was still large (143), they averaged more footnotes than the 209 threc-judge panel decisions (5 and 4, respectively), but in 1975 the averages were almost identical and im 1984-85 en banc decisions were actually less heavily footnoted than three-judge decisions. Opinion lengths revealed the same pattern; en banc decisions were longer in 1965, the same length in 1975, and shorter in 1984-85.

\section{Agency Type}

We had hypothesized that opinions remanding to health, safety, and environmental agencies would be longer and more heavily footnoted than those remanded to other agencies. Most other commentators who have considered this distinction observe that the newer health, safety and environmental agencies generally possess broader and stronger regulatory authority, make very technical decisions, regulate more diverse firms and industries, function under closer congressional, White House and judicial oversight, and operate im a more complex pohtical environment. 196 These agency characteristics, we thought, would produce the hypothesized effects in the length and footnoting of opinions.

Our data suggest some support for this hypothesis but also reveal the magnitude of the change in the regulatory world that occurred in the decades after 1965. In 1965, our sample of non-table decisions contained only one opinion reviewing health, safety, and environmental regulation, and it was one-third shorter than opinions generally (4 pages versus 6). By 1975, after many new "social regulation" agencies had becn estabhished, $11 \%$ of the opinions in our sample reviewed hcalth, safety, and environmental agencies, and those opinions were almost 50\% longer than opinions generally (11.2 pages versus 7.7$)$. By the $1984-85$ period, when opinions reviewing these agencies constituted about $7 \%$ of the sample, those opinions were still longer than opinions generally $(9.3$ pages versus 7.7) but the difference was less. In both 1975 and 1984-85,

196. See, eg., The Politics of Regulation (J. Wilson ed. 1980); Lilley \& Miller, supra note 80, at 49-55; Schuck, The Politics of Regulation (Book Review), 90 Y ALE L.J. 702, 708-11 (1981) (reviewing The Politics of Regulation, supra). 
only one category of agencies-the "other regulatory" grouping-generated longer reviewing court opinions than the health, safety, and environmental agencies (about 1.5 pages longer in both periods).

When we examine the footnoting practices of courts reviewing different kinds of ageucies, the same pattern einerges. The one health, safety, and environmental case in 1965 was less extensively footnoted than opinions generally, but by 1975 such cases were more heavily footnoted than opinions generally; that continued in the $1984-85$ period, although the difference was less. And as with opinion length, the only other category of agencies that generated more extensive footnoting was the "other regulatory" grouping. 


\section{APPENDIX E-ReCONCILIATION WITH ADMINISTRATIVE OFFICE DATA}

The Annual Report of the Director of the Administrative Office of the U.S. Courts contains numerous statistics on the caseload of the federal court system, including soine data on appeals to the U.S. Courts of Appeals from administrative agencies. Although the AO data appear similar to our data, they are not fully coinparable because of several differeuces in their coinpilatiou inethodology.

1) The AO data is published in annual compilatious from July 1 to June 30 of each year, rather than the six-month coinpilations of various months in our study. The differences in time periods complicate direct coinparisous of the datasets by requiring assumptious about the annual distribution of caseloads in the analysis.

2) Second, definitions of terms such as "affirmed" or "reınanded" differ between the two datasets. For example, the AO uses the term "affirmed" to include many cases which are reversed in part, and may be more analogous to the sum of our categories of "affirmed" and "affirmed in part." In additiou, the AO only began reporting "remanded" cases as a separate category in 1985. Some of the definitions may also have changed over time, such as the description of reported cases as "disposed of after hearing or submission" to "termination on the merits" in 1985. It is difficult even to ideutify when some of these changes occurred because most of the terms utilized by the AO are not defined, especially in the older data compilations.

3) The two studies utilize different methods of gathering data, each with its own advantages and disadvantages. The AO gathers its data froin forins completed by clerks in each of the courts as part of the regular paper process, which has the advantage of drawing data from unpubhished decisions and may allow the clerk to utilize information outside of the actual opinion to characterize the case. However, the AO's decentralized subjective categorization of the data may lead to geographical and teinporal inconsistencies. For example, the 1987 data contain soine major errors in one circuit in the characierization of cases as "remanded" or "reversed," and the 1977 data on the administrative appcal caseload and affirmance rate are suspiciously anomalous. The methodology of our study should allow for a more consistent categorization of cases because it is apphed post hoc by relatively few individuals. However, the scope of our study is limited to opinions published within only $10 \%$ of the twenty-year time span of the study. 
4) The AO does not include appeals froin the Patent and Trade1nark Office or froin the Merit Systeins Protection Board in its compilations on administrative agencies. 197

With these differences in mind, a coinparison between the $\mathrm{AO}$ data and our data is presented below. The comparison corrects for the difference discussed in (4) by relnoving the Patent and Tradeinark Office and the Merit Systems Protection Board (MSPB) data from our dataset, and partially corrects for the difference discussed in (2) by utilizing our characterization of cases resulting in "affirmed" or "affirmed in part" to compare with the AO's characterization of "affirmed." Note that our 1985 data cover the period froin February 25, 1985 to September 30, 1985, and thereby extends two months into the AO's 1986 data year.

\section{NUMBER OF APPEALS TO THE U.S. COURTS OF APPEALS FROM ADMINISTRATIVE AGENCIES}

\begin{tabular}{ccc}
$\begin{array}{c}\text { AO's “Appeals Terminated } \\
\text { on the Merits" } \\
\text { July 1 to June 30 }\end{array}$ & $\begin{array}{c}\text { Published Cases in a } \\
\text { Six-Month Period }\end{array}$ \\
\hline 1965 & 489 & 257 \\
1975 & 679 & 251 \\
1984 & 1321 & 557 \\
1985 & 1256 & 557
\end{tabular}

\section{Percent of Appeals to the U.S. Courts of Appeals from ADMINISTRATIVE AGENCIES WHICH ARE AFFIRMED}

\begin{tabular}{ccc} 
AO's Coinpilation & $\begin{array}{c}\text { Published Cases in a } \\
\text { Suly 1 to June 30 }\end{array}$ & Six-Month Period \\
\hline 1965 & $75.1 \%$ & $66.0 \%$ \\
1975 & $69.8 \%$ & $68.5 \%$ \\
1984 & $73.5 \%$ & $77.2 \%$ \\
1985 & $75.9 \%$ & $80.8 \%$
\end{tabular}

Our affirmance rate data and the AO's are close, except for 1965. We strongly suspect that the difference for 1965 is the effect of table deeisions. The AO data include all terminations; a case has to be included in the AO data before it can be removed froin the docket. Our data, on the other hand, were gathered from cases published in the Federal Reporter. For recent years, the difference is not great, since the

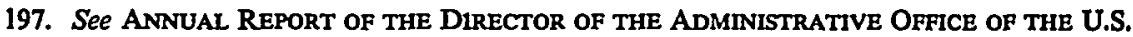
CoURTs 105 (1987) (Table S-1, "U.S. Courts of Appeals; Appeals Filed by Circuit Involving Administrative Agency Decisions During the Twelve Month Period Ending June 30, 1987"). 
bound volumes now include nost of the decisions that were previously unpublished. The difference was presumably much greater in 1965, before the Federal Reporter began to report table decisions. 